Historic, archived document

Do not assume content reflects current scientific knowledge, policies, or practices. 


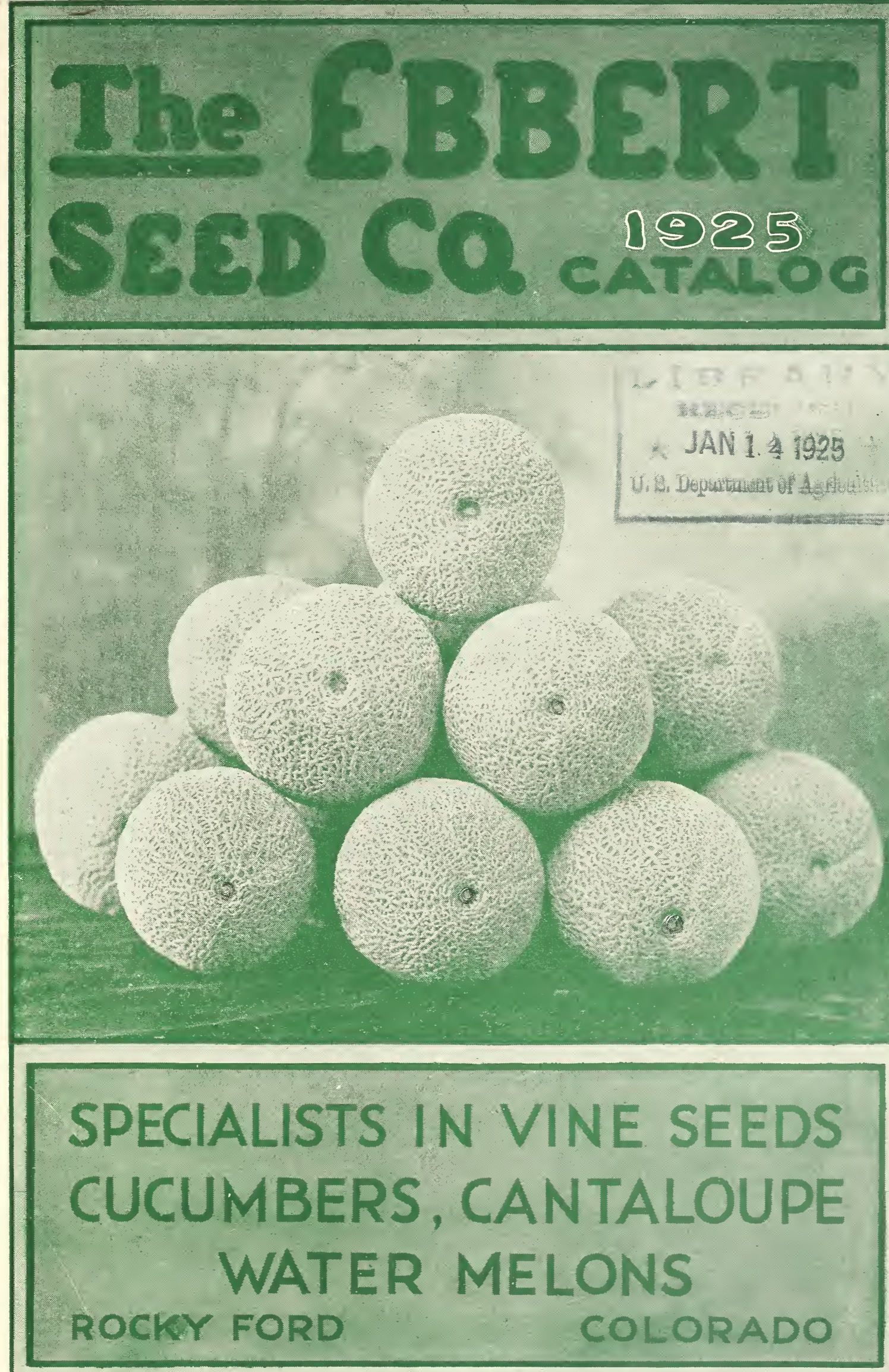


\section{Ebbert's Select Cantaloupe Seed}

We are located in the heart of the greatest Cantaloupe Seed growing district in the world-where the growing of good seed is a science and where soil and climate are ideal. Our Cantaloupe Seed is known everywhere for high quality. Don't take shances, send us your order.

\section{Progress in Producing Vine Seeds}

We are striving each season, by careful seed selection, to improve and perfect the different strains of the Rocky Ford Cantaloupe and the standard varieties of Cucumbers.

The many flattering letters received from all sections of the country lead us to believe that our efforts are being appreciated and bearing fruit. We are sparing neither time nor expense to show our appreciation of the confidence placerl in us by our rapidly increasing list of "satisfied customers."

All seeds are carefully tested before being shipped.

We grow Cantaloupe and Cucumber seed, under contract, for some of the largest associations and individual growers in the principal growing sections of the United States. Those using quantities of vine seeds should write for our Special Contract Growing Prices. We will giow any variety required, either from our own especially selected stock seed or from seed furnished by the purchaser.

Our reputation has been built up by furnishing seeds of the best quality as to purity and germination, and we shall always encieavor to furnish the best seeds that can be produced and make prices as reasonable as possible.

It is very gratifying to us to be able to say that the past year was far ahead of any previous year in the sales of vine seeds. Vine seeds are our specialty. We produce our own vine seeds which develop and mature perfectly under irrigation.

We assure you that any orders or inquiries you may favor us with will receive our prompt and careful attention.

Thanking you most sincerely for your patronage in the past and anticipating with much pleasure your orders for the coming season.

WE ARE

The

HEADQUARTERS FOR SELECT

CANTALOUPE SEED.

WHEN YOU BUY

OUR SEED

YOU BUY THE BEST.

Ebbert

Seed

Company

Rocky Ford, Colo. 


\section{TH'E EBBERT SEED COMPANY}

\section{9-411 North Main Street}

\section{Rocky Ford, Colorado}

Please read "How to Order" (in front of catalog). More order sheets will be sent upon request. Always write letters on a separate sheet from your order.

VERY IMPORTANT-Write your name very plainly, and give your Postoffice, County and State in full every time.

$\left.\begin{array}{l}\text { Dorward by }\left\{\begin{array}{c}\text { State on this line whether wanted } \\ \text { by Mail, Express or Freight }\end{array}\right\} \\ \text { EXPRESS OR FREIGHT OFFICE } \\ \text { If different from postoffice }\end{array}\right\}$

\section{Amount Enclosed} $\$$

Cash

Draft

P. O. Order

Express Order.

Stamps

ORDER NO.

QU.
LbS.




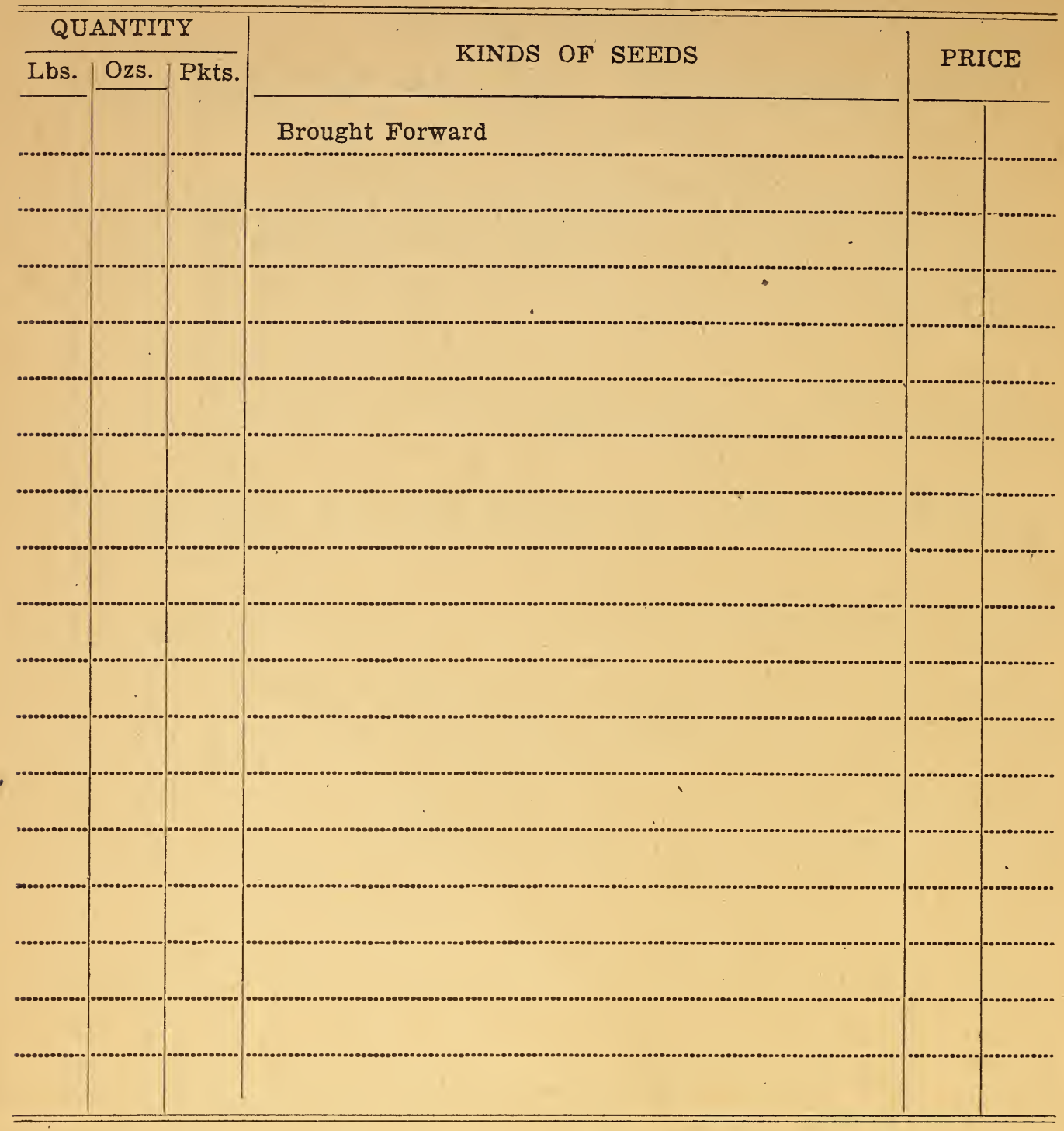

An order this season, no matter how small, secures our catalog for next year as soon as it is issued.

With each order we will send a packet of any of our favorite varieties of Cantaloupe Seed to any one who will send us the names of five market gardeners, or five people who buy seeds. 


\section{Information for Purchasers}

\section{Please Read This Page Carefully}

(For Index of Contents See Page 48)

$W^{c}$

E PAY POSTAGE. Please remember, in comparing our prices with those quoted by other seedsmen, that we pay the POSTAGE on all seeds quoted in this catalog, by the packet, ounce, quarter-pound and pound-except on Onion Sets and field seeds, on which our prices named are NET, and if ordered by mail you must send 8 cents per pound, to cover postage.

If seeds are ordered by freight or express, at your expense, deduct 8 cents per pound from catalog prices (except as above noted).

OUR TERMS are strictly cash with order. Remittance should be made by Postoffice or Express Money Order, Bank Draft or Registered Letter. Amounts of less than $\$ I$ may be sent in postage stamps.

If personal checks are sent they must be certified by your banker.

We do not ship seeds C. O. D. unless one-third of the amount of the purchase price accompanies the order. C. O. D. shipments cannot be made by freight.

HOW TO ORDER. Be sure to write your name PLAINLY; also your Postoffice, County and State. Give the name of your freight and express office if different from postoffice. Always state whether to ship by Mail, Express or Freight.

USE OUR ORDER SHEET, carefully filling out the blank spaces at the top, for shipping directions. Use one line for each kind of seed ordered.

Always carry out the price of each item.

Keep a copy of your order. (This is Very Important.)

We exercise the utmost care in filling orders, striving to be correct in every detail; yet in the press of business errors sometimes occur, in which event we wish to be promptly notified of the fact and will make such corrections as will be satisfactory.

WHEN TO ORDER. We strongly advise our customers to send in their orders immediately upon receipt of this catalog, as they will then have the seeds on hand when they need them, and avoid the unnecessary delay often caused by the rush of the busy season. It is advisable to order while our stock is complete.

The prices we quote on Vegetable and Flower Seeds in this catalog will hold good as long as our stock lasts.

Should you want any articles not listed in this catalog we will be pleased to have your inquiries and will give them prompt attention.

MARKET GARDENERS AND LARGE PLANTERS should write for Special Prices, stating variety and quantity required.

WARRANTIES. Seeds of the best quality will often fail through improper treatment, by sowing the seed too deep or too shallow; in too wet or too dry soil. They differ greatly as to temperature required for germination. Some will germinate rapidly at a certain temperature, while others, if sown under the same conditions are apt to decay. The young plants are liable to various accidents. Cold or dry air may check their growth or destroy them. Insects above and below the ground may attack them and a great many other contingencies may arise to prevent the best seeds from giving satisfaction. Wo use every precaution in procuring fresh, pure and reliable seds, etc., but we, in common with other responsible seed houses, sell our goods subject to the following disclaimer, it beirg that adopted by the American Seed Trade Association, i. e.: We give no warranty, express or implied, as to description, quality, productiveness or any other matter of any seeds, bulbs or plants sent out; and will not be in any way responsible for the crop. If the purchaser does not accept the goods on these terms they are at once to be returned.

\section{The Ebbert Seed Company}

OUR RESPONSIBILITY: As to our financial and business standing, we refer you to the leading commercial agencies, any bank or business house in Rocky Ford or Otero County, Colorado. 


\section{Rocky Ford Cantaloupes}

The Cantaloupe Seed we offer for sale is all grown by ourselves and carefully observed and tested as to profitable merits of each strain and we believe the seed we offer is as good as systematic selection can produce.

\section{Improved Pollock, or Eden Gem}

One of the best known strains of the Improved "Rocky Ford" or solid meat type-rust-resistant.

This variety is a great favorite with southern shippers. Every season shows an increased acreage of this variety, not only in this district but in the principal growing districts of the country.

This melon is the earliest of the solid net type, and the most prolific; runs very uniform in size. In shape it is nearly round, with no ribs, and heavily netted. The color of the flesh varies from green to golden yellow, is soljd, fine grained, and of the finest flavor. A splendid shipper. Makes a fine appearance on the market.

Our seed crop of this varieiy was extra fine the past season.

Select seed (saved from the earliest and best melons), Pkt., 5c; 0z., 15c; 1/4 Ib., 40c; per Ib., 15 0z., \$1.00.

Write for prices on larger quantities.

\section{Pollock No. 25}

This cantaloupe is rapidly growing in favor, having filled all the requirements for a pink meat melon, being an early, prolific, rust-resisting melon of standard uniform size. Well netted; good shipper. Flesh, light pink, running to salmon color.

Select seed, pkt., 5c; 0z., 15c; 1/4 lb., 50c; I lb. of 15 oz., $\$ 1.25$; 10 lbs., $\$ 1.00$ per Ib.

Write for prices on larger quantities.

Please bear in mind that our prices include transportation charges.

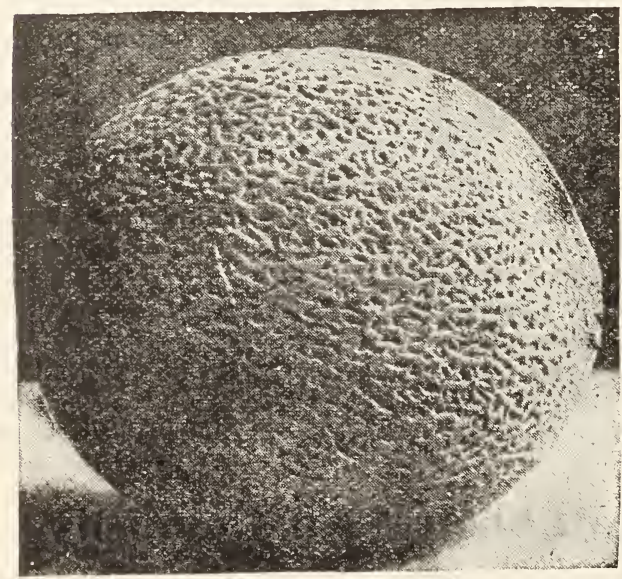

Improved Rust Resistant

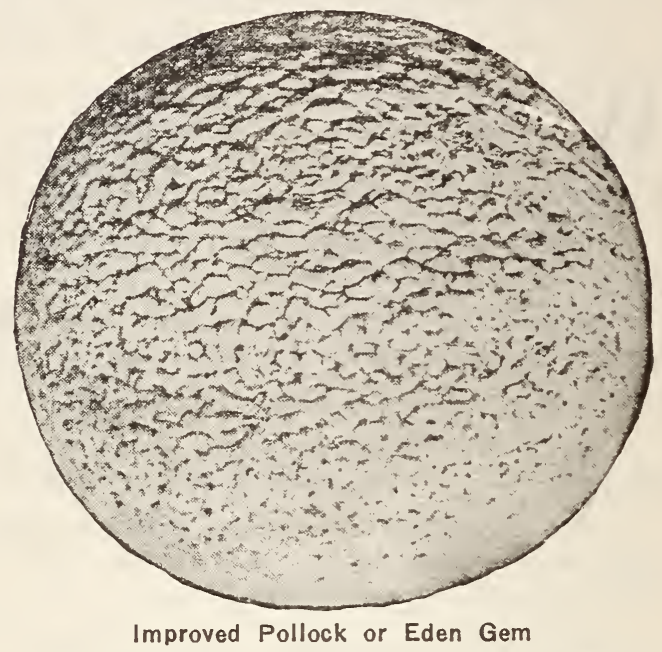

Our Improved Rust Resistant Rocky Ford Cantaloupe

We consider this type the highest development, both as to netting and rust-resistant qualitles, yet attained in the Rocky Ford Cantaloupe.

While the vines of some varieties are entirely killed by rust and blight before the shipping season closes, the vines of this variety are green, continuing to blossom and set on fruit until killed by frost.

The melons run uniform standard size, the ex. ceptionally heavy netting being laced over the entire surface of the melon, making it an ideal shipper.

It is green fleshed, shading to salmon about the seed cavity, which is unusually small. The flesh is solid and fine grained, flavor unexcelled. While a few days later than the Eariy Watters it is more prolific (often yielding from 200 to 300 crates per acre). We highly recommend this variety for all sections of the country, and especially to those sections that have excessive rainfall.

Plant our improved RUST IRESISTANT the coming season. You will get results. It will not disappoint you. The seed we offer were especially grown for seed and of the finest possible selection. Pkt., 5c; 0z., 15c; $1 / 4$ lb., $40 \mathrm{c}$; per Ib. 15 0z., $\$ 1.00$.

Write for prices on larger quantities.

\section{Our Netted Rock King}

Is an improved type of the original green meated Netted Rock Cantaloupe, having small seed capacity, thick salmon-pink flesh, with all other qualities similar to the Van Buskirk Netted Select seed, pkt., 5c; 0z., 15c; 1/4 lb., 40c; 1 Ib., $\$ 1.00$.

We list as specialties the leading strains of the Rocky Ford Cantaloupe. 


\section{Van Buskirk's Netted Rock}

This is the most popular of the Improved Rocky Ford, or Solid Net type. It has taken more premiums than all other varieties combined, and represents the highest possible attainment in cantaloupe dedevelopment. It is undoubtedly the heaviest meated melon of the Rocky Ford type.

The flesh is green, tinged with a delicate salmon colored pink around the seed cavity, which is by far the smallest of any strain of the Rocky Ford. The flesh is sweet, luscious and melting, and of a delicious flavor.

The Netted Rock has by actual test, stood up hard, firm and brittle several days longer than any other melon yet tried at Rocky Ford. This kind of $a$ test is what the grower wants to know about, for it is cantaloupes such as the Netted Rocks which are hard, firm, sweet and juicy when they arrive on the market that makes the grower the money.

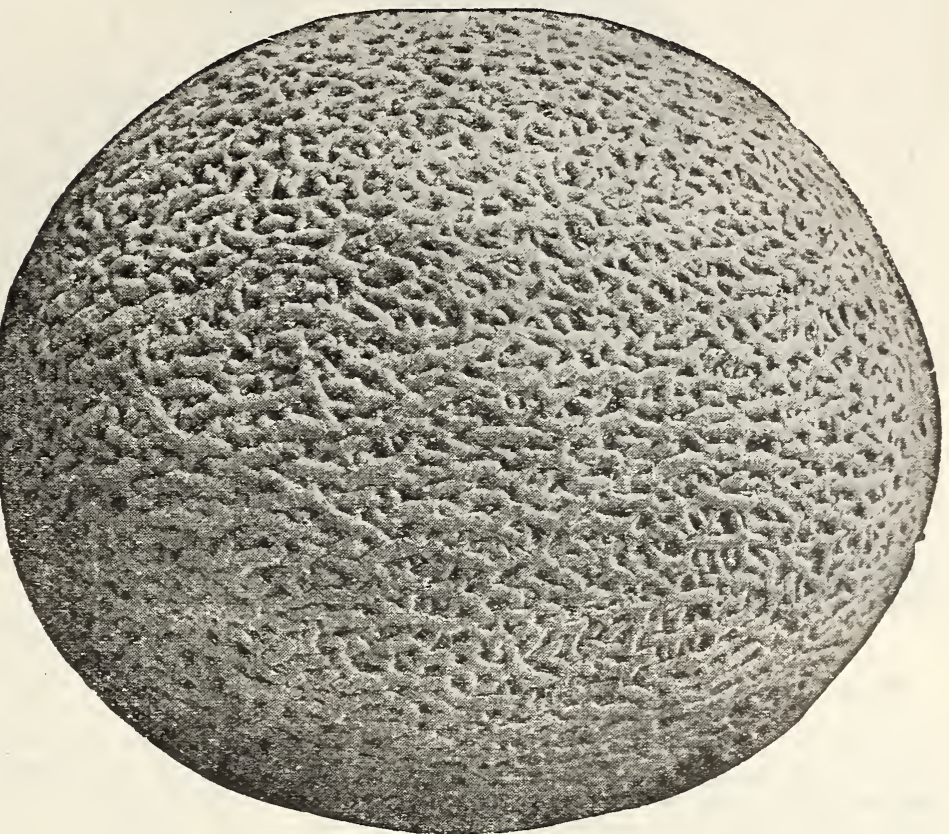

Van Buskirk's Netted Rock

The seed we offer was grown from the finest selection of the first melons to ripen.

Select Seed (saved from finest melons), pkt., 5c; 0z., 15c; 1/4 Ib., 40c; per Ib., 15 0z., $\$ 1.25$; 5 to $10 \mathrm{lb} ., \$ 1.00$ per Ib.

\section{Salmon Fleshed Rocky Ford}

(KNOWN AS BURRELL GEM, OSAGE GEM AND ORDWAY PINK MEAT).

During recent years this variety has become a very popular melon with our Colorado growers; also a very profitable one. When wrapped and packed in one layer crates, holding from 12 to 15 melons, it has sold much better in proportion than the Rocky Fords shipped in standard crates. It is rapidly growing in favor in the markets throughout the country. The melon is larger and longer than the Rocky Ford, averaging about six inches in length and four and a half to five inches in diam. eter with well defined ribs, beavily netted, with a distinct stripe between. The flesh is a rich salmon color and fine grained. The seed cavity is un- usually small, which accounts for its superior ship. ping qualities.

The flavor is entirely different from that of the "Rocky Fords," but is rich, sweet and spicy, and preferred by many to the green fleshed varie ties. This melon should not be picked until it will slip from the vine, and should not be planted extensively where there is a leavy rainfall, as it is inclined to crack with excess moisture. Select pkt., 5c; 0z., 10c; 1/4 lb., 30c; 15 0z., \$1.25; 10 to $25 \mathrm{lb} ., \$ 1.00$ per ib.

Write for prices on larger quantities.

\section{Improved Salmon Tint Cantaloupe}

\section{Pollock No. 10-25}

This valuable selection which in general appearance resembles the well known Pollock No. 25 has proved generally satisfactory and quickly become the most popular variety ever introduced. The flesh is \& deep salmon tint very fine grained and of a delicious flavor, produces a heavier crop of uniform marketable melons than any variety yet introduced, has a very small seed cavity and because of its splendid shipping qualities is now planted more largely in California than all other varieties combined. The seed we offer is carefully selected from fields grown for seed purposes only, from melon true to type, well netted, fully matured and of standard size selected for their seed qualities and is as good seed in every way as can be produced. Pkt., 5c; oz., 15c; 1/4 lb., 30c; lb., \$1.25; 10 to 25 ibs., $\$ 1.00$ per 16 . Write for special prices on larger quantities.

\section{Abbott's Pearl Cantaloupe}

\section{THIS SPLENDID NEW VARIETY HAS BEEN BUT RECENTLY INTRODUCED}

It is one of the very best pink meat varieties and in most respects far superior to any other of this class. The fruit is of standard size, oval in shape, covered with a beautiful heary gray netting. The flesh is firm, finely grained and of a rich deep salmon pink color; the flesh extends to the rind, retaining its color and firmness so that the edible portion can be removed with a spoon, leaving rind no thicker than that of an orange. The vine is vigorous and very productive. This variety because of the hard firm rind and small seed cavity, bears shipment better than any other variety yet introduced. It is altogether the most desirable of the pink meat sorts. We would especially recommend it to our customers. Select seed (saved from standard size melons), pkt., $5 \mathrm{c}$; 0z., 150 : 1/4 Ib., 40c; Ib., \$1.25; 10 Ibs., \$1.15; 100 Ibs., $\$ 1.00$ per Ib. 


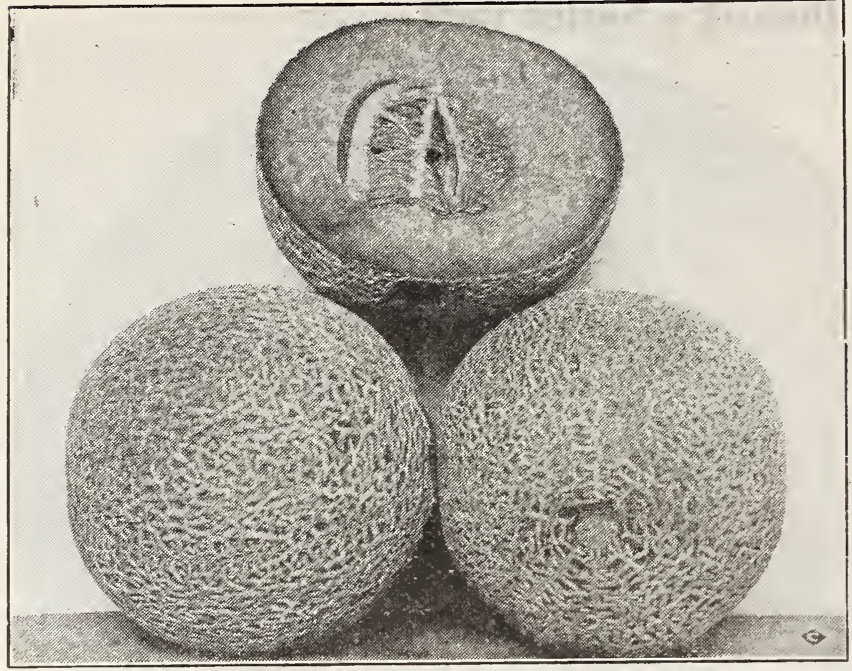

Edwards Perfecto

\section{Try the Famous Honey Dew Melon}

The long distance shipper and money maker has broken all records for heavy yields and net returns, carlot shipments being made from this section up to November 1 st.

Much more prolific than cantaloupe, will give heavy yields in any section where cantaloupe will produce, planted at the same time, matures two weeks later than cantaloupes. Average size, six inches in diameter, eight inches in length; weight five to six pounds; skin at maturity, smooth, creamy yellow; flesh, light green, fine grained; very thick juicy meat to extreme rind; of a rich, fruity flavor: unsurpassed. Pkt.. 10c; oz., 20c; $1 / 4 \mathrm{lb}$., $50 \mathrm{c} ; 1 \mathrm{lb}$. of 15 oz., $\$ 1.00$.

Write for prices on larger quantities.

\section{Ebbert Seed Co.'s Improved Hoodoo Melon}

Hearts of Gold - A splendid type of the almon fleshed cantaloupe. It is early and prolific. Similar in shape to the Rocky Ford but slightly flattened from stem to blossom end. The ribs are completely covered with a heavy, close netting, with a very narrow siripe between. Flesh salmon colored, thick, fine grained and of delicious flavor. It is an ideal shipping melon and sure to become a favorite with all who prefer a salmon fleshed melon. Don't fail to give it a trial. The seed we offer is of our own growing from the originator's stock. Pkt., 5c; 0z., 15c; 1/4 lb., 40c; Ib., $\$ 1.00$.

\section{Edwards Perfecto}

We consider the table qualities of this large pink meated melon equal to any other variety on the market: deliciously sweet, deep flesh with very small seed cavity, round in shape covered with a deep silvery netting; good shipper and attractive appearance when displayed on the market. Our seed of the best se. lection. Pkt., 5c; 0z., 15c; 1/4 Ib., $40 c$; $1 / 2$ lb., 65c; 1 lb., \$1.00. Spe. cial prices on larger quantities.

\section{Ebbert Seed Co.'s Early Watters}

(Also known as Imperial Gem and Hybrid No. 2)

(The Earliest of the Rocky Ford Cantaloupes)

It is very prolific and usually the first setting of the fruit is very heavy, often 12 to 15 marketable melons to the hill, mostly ripening about the same time, the bulk of the crop being marketed in about two weeks. In shape and earliness it somewhat re sembles the "Original Rocky Ford," but is much inclined to run to the solid net. The melons are well netted and of uniform size. The flesh is light green and of the best quality. The seed cavity is somewhat larger than in the improved solid net types, therefore is not as good a long distance ship. per; but for home use and nearby markets it is one of the best. We cannot recommend it for sections of the country where rainfall is excessive, as the vines are inclined to rust or blight, but where early melons are an object, and in the Southwest where melons are grown entirely by irrigation with practically no rainfall, it is the most valuable of the Rocky Ford strains. Select stock, pkt., 5c; oz., $15 \mathrm{c} ; \mathrm{I} / 4 \mathrm{Ib} ., 40 \mathrm{c} ; \mathrm{Ib} ., \$ 1.25 ; 10 \mathrm{Ibs}$. and up, $\$ 1.00$ per $\mathrm{Ib}$.

\section{PRIZE COLLECTION OF SEEDS-30 REGULAR 5c PACKETS, VALUE \$1.50-SENT POSTPAID FOR $\$ 1.00$}

Pkt. Beet, Long Blood.

Pkt. Cabbage, All Head Early.

Pkt. Cabbage, Giant Surehead.

Pkt. Carrot, Oxheart or Guerande.

Pkt. Celery, Giant Pascal.

Pkt. Cucumber, Everbearing.

Pkt. Corn, Sweet.

Pkt. Lettuce.

Pkt. Muskmelon, Perfection.

Pkt. Watermelon.

Pkt. Onion, Red Wethersfield.

Pkt. Parsnip, Hollow Crown.
Pkt. Peas, Surprise.

Pkt. Pumpkin, Japanese Pie.

Pkt. Radish, Long Scarlet.

Pkt. Spinach, Thick Leaved.

Pkt. Squash.

Pkt. Tomato, New Tree.

Pkt. Turnip, Early White Flat Dutch.

Pkt. Garden Lemon.

The entire lot of 20 packages will be sent by mail, postpaid, for $75 \mathrm{c}$.
Pkt. Aster, Favorite Collection.

Pkt. Calliopsis, Mixed.

Pkt. Celosia, Mixed.

Pkt. Cosmos.

Pkt. Hardy Garden Pinks.

Pkt. Hollyhock, Mixture.

Pkt. Nasturtiums, Mixed.

Pkt. Mignonette, Mixed.

Pkt. Poppy, Mixed Colors.

Pkt. Sweet Peas, All Colors.

This lot sent by mail postpaid, for only $50 \mathrm{c}$ 


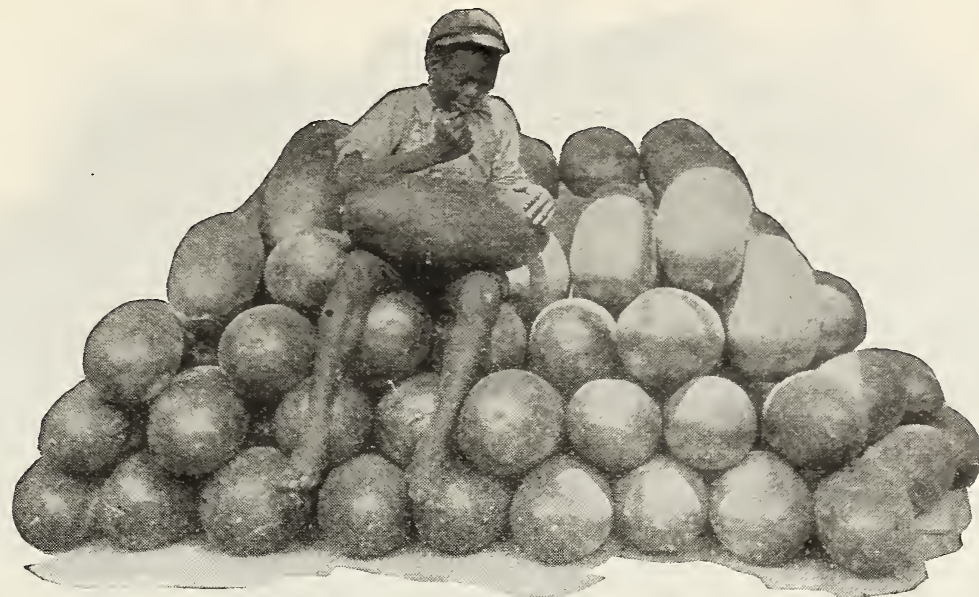

A Fine Shipment of Our Tom Watsons

\section{Watermelons}

Choice Watermelon seed is one of our specialties. We handle nothing but the best. All our stock is strictly fresh. The varieties that we do not produce are grown for us under contract by one of the best known seed "specialists" in the South. We list as specialties two of the best watermelons over produced. For General List of Watermelons see pages 23 and 24 . Remember that our prices include delivery charges.

\section{The Watson, or Tom Watson Watermelon}

A now watermelon, combining the eating qualIties of the "Kleckley" and the shipping qualities of the "Alabama Sweet."

The Watson originated in feorgia, the "home of the watermelon." Wherever introduced, and particularly in the melon growing districts of Texas and Indiana, it takes the lead over all other varieties. The fruit is very large, many melons weighing 50 to 60 pounds and measuring 18 to 24 inches in length. The skin is a dark mottled green; the flesh is an intense bright red, solid and tender; the heart is very large, with a very small seed area. The rind is very thin, but excedingly tough, which accounts for its excellent shipping qualities. The flavor is second to none. This grand melon is sure to become a leader whereever introduced. Our stock of seed was grown especially for us, and is of the finest selection. This season we have a good supply, but yet do not expect to be able to supply the rapidly increasing demand. Place your order early. Pkt., 5c; 0z., 10c; 1/4 lb., $30 c$; lb., $\$ 1.00$; 5 to 10 lbs., 90c per lb.: 10 lbs. or more, $85 \mathrm{c}$ per lb.

\section{Ebbert Seed Co.'s Improved Kleckley Sweets}

The "sweetest of all" watermelons, the best home and nearby market melon yet Introduced.

This splendid variety is the finest flavored melon introduced in recent years. As a melon for the home garden and local market it is unexcelled. As originally introduced, the rind was too thin and tender to admit shipping, out by careful selection this defect has been largely overcome, and at the present time is the favorite shipping melon with our Colorado growers, and rapidly growing in favor in other sections of the country.

In this new strain, now offered, there is developed a melon with a shell hard enough to carry to market, having been carefully selected for a series of years for this result. The rind is not thick, but the skin is so hard and tough that it resists the jolts and jars of travel to a remarkable degree.

The melon is large, averaging about 25 pounds in weight, oblong in form, with very dark green skin, flesh deep scarlet red, with solid heart, stringless, with few seeds set near the rind. The flavor is unexcelled. Don't fail to plant this splendid melon for home use or nearby markets. Place your order early. Pkt., 5c; 0z., 10c; I/4 Ib., 30c; Ib., \$1.00; 5 to 10 lbs., 90 c per lb.; 10 lbs. or more, 85 c per ib.

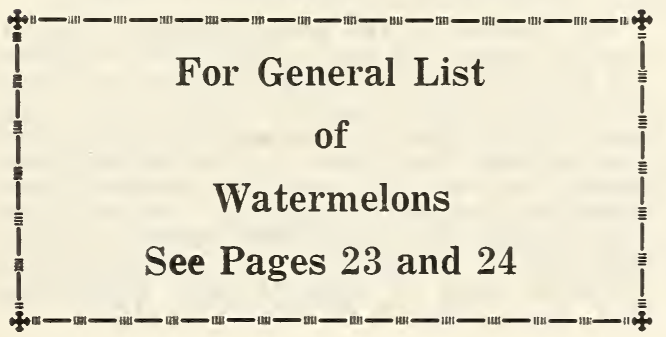

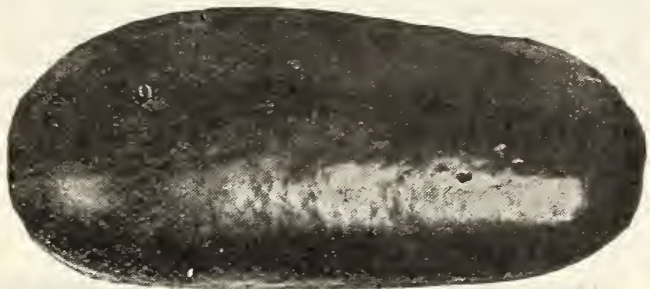

One of Our Improved Kleckley Sweots 


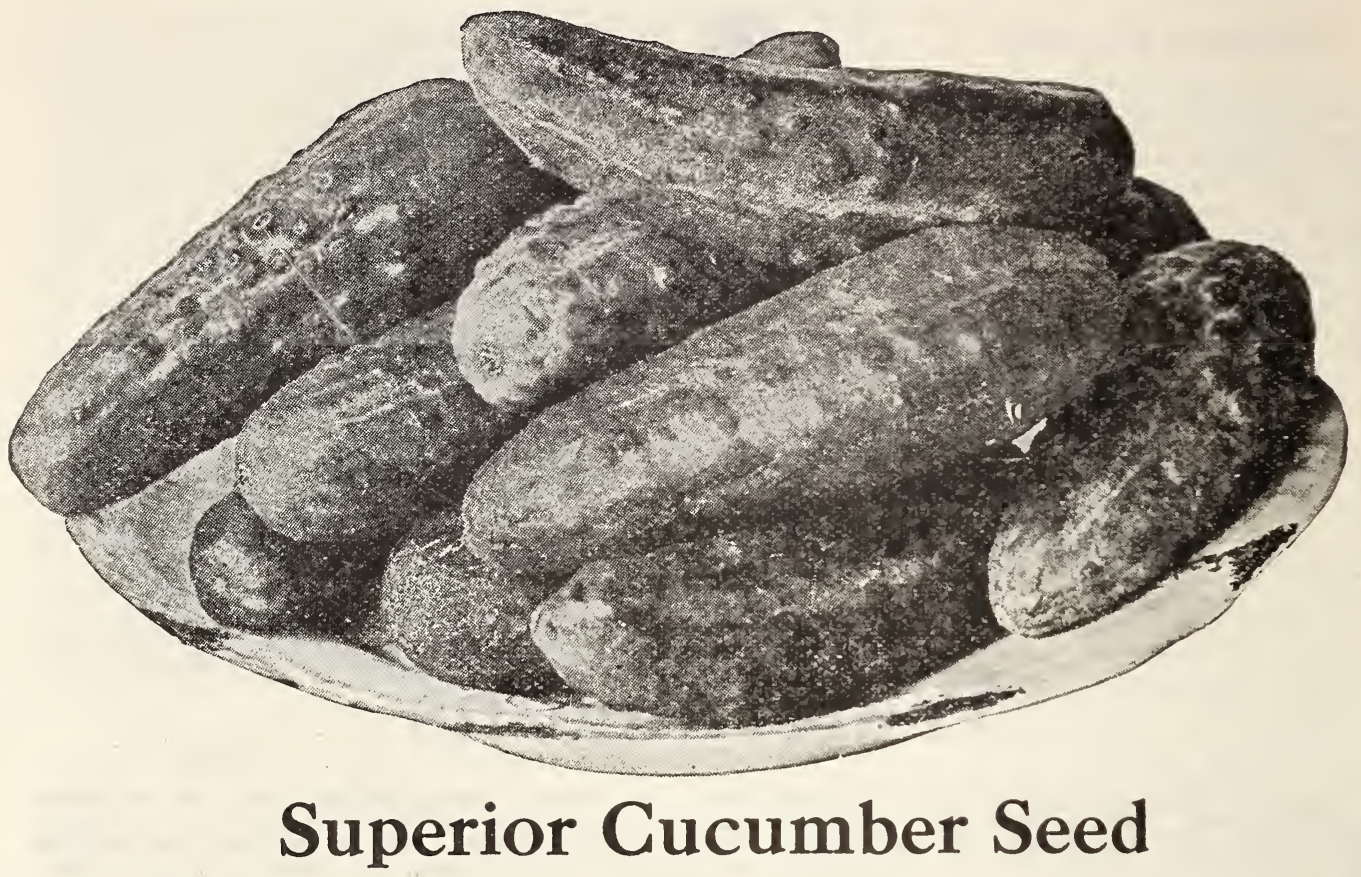

The Rocky Ford District is as well known for the production of high grade cucumber seed as it is for the production of a superior grade of cantaloupe seed. With irrigation, abundant sunshine, and ideal weather for harvesting the seed crops, we produce seed of a superior quality, and of the highest germination. The leading seedsmen of the country now depend on this district for their supply. We supply seedsmen from California to Rhode Island.

We list herewith a few varieties of special merit. (For general list, see pages 17 and 18).

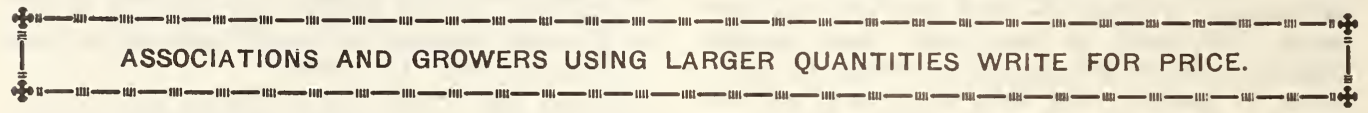

\section{Davis' Perfect Cucumber}

Seed Supply Very Short

This valuable cucumber is fast becoming a gen. eral favorite In the large growing districts.

This ideal cucumber is equally good for growing under glass or outdoor culture. When grown out of doors it resembles the hot house product so closely that dealers will pay the same high prices for it as for the hot house grown.

The color is a dark glossy green; shape lender and symmetrical, average length 10 to 12 inches. Contains but few seeds and is ideal for slicing. The vines are extremely vigorous and productive and resist blight lietter than other long sorts. A great favorite in Florida and other sections of the South for shipping to Northern markets. For market gardeners it is the most profitable variety known today. We offer extra select seed of our own growing. Pkt., 10c; 0z., 15c; 1/4 lb., $40 c ; 1 b ., \$ 1.25$.

\section{Ebbert Klondike}

\section{(A ROCKY FORD PRODUCTION).}

This splendid shipping cucumber is our improved -train of the White Spine type. Early and prolific. continuing to bear throughout the season. Uniform in size, average length 7 to 8 inches; color very dark green, with pale green stripes extending from the blossom $\in$ nd. The fruit firm and hard; keeps in prime condition and retains its dark green color for a long time after picking.

One of the best shipping varieties and a leader in many sections of the country. Our orders on this variety the past season increased more than 100 per cent. Seed is of our own growing and of the finest possible selection. Pkt., 10c; 0z., 15c; I/4 Ib., 40c; Ib., \$1.00.

\section{Ebbert's "Earliest of All"}

The earliest of the slicing varieties. Fruit is straight, smooth and firm; excels all other varieties for pickling or slicing; vines vigorous and most productive, yielding more fruit per acre than any other variety grown for market; fruit good, even size, and dark green color. All our customers that planted our seed last year, are increasing their orders for next season's plauting. Discarding the older varieties and using Ebbert's Earliest of All 28 the best on the market. We recommend this Cucumber above all others for Early Market Use. Pkt., 5c; 0z., 15c; 1/4 lb., 40c; 1 lb., \$1.25. 


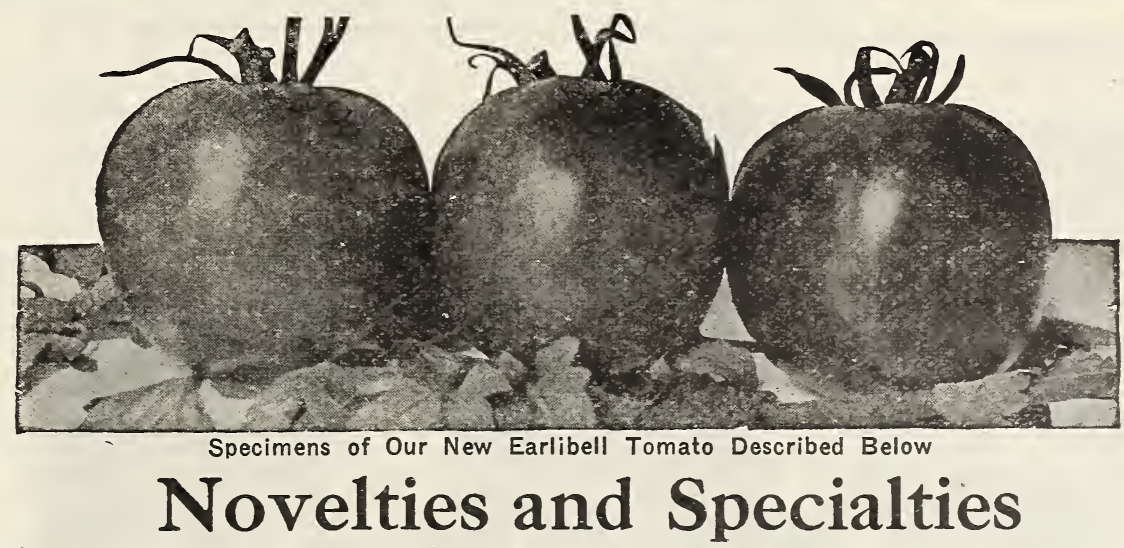

You will find under this heading new varieties worthy of trial, and others of such value as to warrant our giving them special mention. There are varieties which, while not new in the strictest sense of the word are of recent introduction and demand special notice as being superior to ordinary types, and these we hope our customers will try along with some of the novelties. They are moneymaker. for those who grow for the market, besides being the most valuable for the home gardens.

\section{Ebbert Seed Co.'s New Earlibell Tomato}

The Earlibell is earlier than any other sort without exception. In a comparative test with Earliana, seeds sown at same time and plants set out at the same time, the Earlibell gave ripe fruit five days sooner. Earlibell is suprisingly productive.

The vines are vigorous and very hardy, with medium heavy foliage, setting fruits close to the main stem and bearing continuously until frost.

Its color is a beautiful deep glossy scarlet, which makes the fruit very attractive when exposed for sale. Its flavor is all that can be desired, making it a splendid sort for slicing or for eating. The fruits ripen uniformly all over, the stem end coloring up perfectly. It cannot fail to give entire satisfaction and more profit than any other. Pkt., 10c; $1 / 2$ 0z., 20c; 0z., 35c; $1 / 4$ lb., $\$ 1.00$.

\section{Frost Proof Bean}

So called because of its ability to withstand killing frosts in the early spring. It may be planted soon 28 the ground is free enough of frost to be tilled and is not affected by frosts which may occur later; they are principally used for green beans, the pods are entirely stringless and must be cooked while quite young. They are very prolific and continue to bear throughout the spring and summer and are especially adapted to Northern planting. Pkt., 15c; lb., 40c; 2 lbs., 75c, postpaid.

\section{Winter Watermelon King and Queen}

Sometimes called Winter Queen or Black Seeded Ice Cream.

This new melon is rapidly coming into favor because of its many good qualities. It is of citronlike appearance, very light in color with a slightly darker stripe, size about ten inches in diameter, averages about 20 lbs.; seed small, shiny black, flesh pink, solid and stringless. The flavor, sweet and surprisingly delicious; is entirely distinct from a watermelon. Like the Casaba, it should not be eaten right off the vine but should be allowed time to become mellow; can be kept in perfect condition until holidar time. Pkt., 5c; oz., 10c; 1/4 lb., 35c; 1 ib., $\$ 1.00$.

\section{Pink Meat Honey Dew}

The fruits of this fine new variety are of mo dium size round os slightly oval, the skin is smooth with an occasional net, when ripe creamy yellow in color, flesh thick, beautiful salmon color of a very sweet sugary flavor. Its merits have been fully demonstrated; stands shipping perfectly and stays in cood condition for weeks after being removed from the vine. Pkt, 10c;0z., 15c; $1 / 4 \mathrm{lb}$., $45 \mathrm{c}$; /b., $\$ 1.50$, prepaid.

\section{Cabbage, "Glory of Enkhuizen"}

A comparatively new Cabbage from Holland, it has met with exceptional popularity on account of its earliness, sure headedness and fine keeping quality. It is very early and large, always extremely solid and fine ribbed-more so than any other kind. It is exceedingly tender, fine grained and as a cropper no early Cabbage will approach it. Is good flavored and keeps in fine condition a long time. It is very dwarf and compact, allowing of close planting. Heads fine, ball-shaped, and with few outside leaves. Size ideal for marketing. Once known, it will hold its own with the market gardeners and home growers alike. Pkt., 5c; 0z. $25 \mathrm{c}$; $1 / 4$ lb., 80c; $1 / 2$ lb., \$1.50; lb., \$2.50.

\section{Sweet Salad Pepper (Pimento) ALSO KNOWN AS PERFECTION}

Especially desirable for canners. Also fine for garden, green and ripe. Smooth and uniform in shape, skins can be easily slipped off after burning over a hot fire, or boiling a few minutes. Pared like an apple by using a sharp knife. The green peppers can be pared best in this way.

Quality very sweet and delicious and entirely free from pungency. Color when ripe a beautiful scarlet red. Very productive, yielding heavy crops until cut off by frosts. Laigely grown by canners for pimentos, pickles and pulp. Pkt., 10c; 0z. $40 \mathrm{c} ; 1 / 4$ lb., $\$ 1.40$; lb., $\$ 5.00$.

\section{Giant Gibraltar}

A Splendid Onion of the Prize-Taker Type

Grown alongside of Prizetaker, this excellent type is especially noticeable on account of its bluish green, glossy foliage which resists insect attacks to a remarkable extent. Ripened bulbs greatly resemble Prizetakers in size and shape, but the skin is, perhaps, a little more of a straw yellow. Worthy of a careful trial. Pkt., 15c; 1/2 0z., 20c; 0z., 35c; $1 / 4$ lb., $\$ 1.00$.

\section{Sibley or Pikes Peak Squash}

We consider this one of the very best winter va. rieties. It has the reputation of being the only variety surpassing the Hubbard in quality. Shell hard, dark olive green color, flesh light orange of the very best quality. Vines of strong growth and very productive. Postpaid, pkt., $5 \mathrm{c}$; 0z., $15 \mathrm{c} ; 2$ oz., $25 \mathrm{c}$; $1 / 4$ Ib., 40c; Ib., \$1.25.

\section{Excel Watermelon}

A large, long dark green melon with faint stripes. A good shipping melon, tough rind and very prolific. Flesh red, crisp and solid, medium early. Pkt., 10c; 0z., 20c; 1/4 lb., 65c; lb., \$1.50, postpaid. 


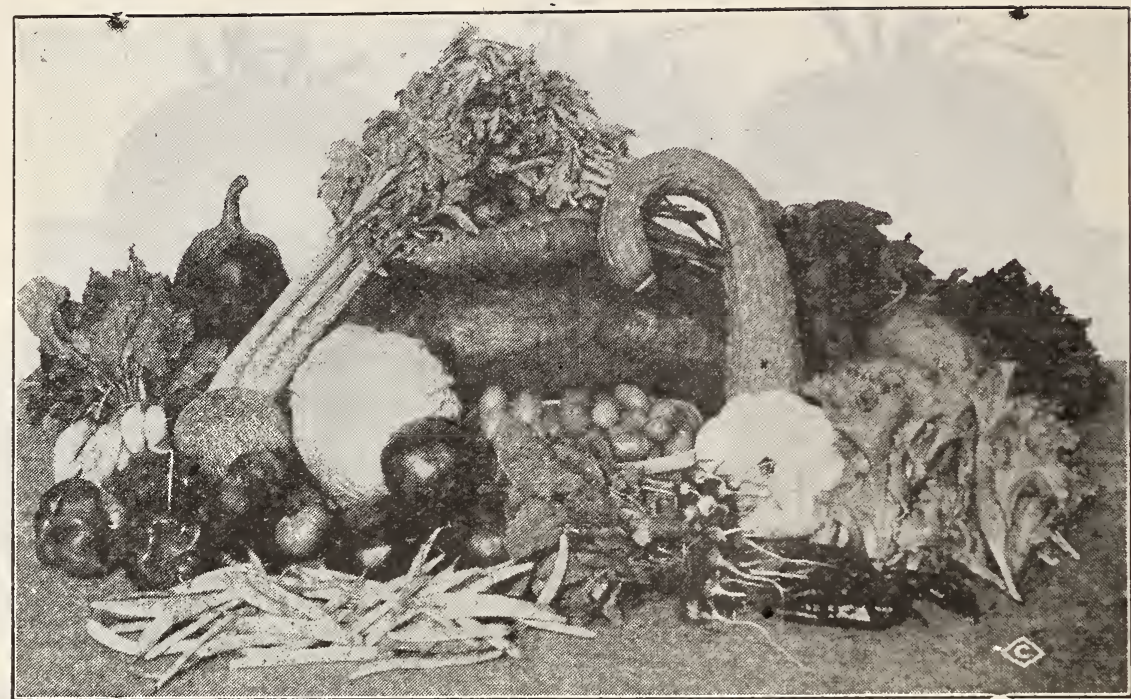

\section{Ebbert's Vegetable Seeds}

With general directions for cultivation. We prepay postage on Beans, Peas, Corn and Onion Sets in pound lots. On other vegetables or flower seeds we pay postage, except where otherwise noted.

\section{Asparagus}

A bed of Asparagus furnishes the first green delicacy of the early spring and calls for little care to make it a success.

Culturo-As early in the syring as the weather permits, spade the ground deeply, working in plenty of well rotted manure or fertilizer. Place the rows three feet apart, and get the roots 1 foot apart in the row, which should be 4 to 6 inches deep. Cover the crowns of the plants with rich soil, and as they grow, give frequent cultivation. $\Delta$ sparagus seed may be sown directly in permanent beds and the plants thinned out as they grow. Sow thinly, about 2 inches deep. Thin out the seedlings to 6 inches apart and take out every other one the following year, so as to get them a foot apart. Fair crops may be expected the third year from seed, but for the home garden we advise that well-grown, two-year-old roots be planted.

One ounce will sow 50 feet of drill and produce about 300 plants.

Palmetto-The most popular variety for the home garden or market. 'The best known green variety. Equally adapted for North or South. Early, large, productive and of excellent quality. Shoots are light green. Pkt., 5c; 0z., 10c; 1/4 lb., 30c; lb., $80 \mathrm{c}$.

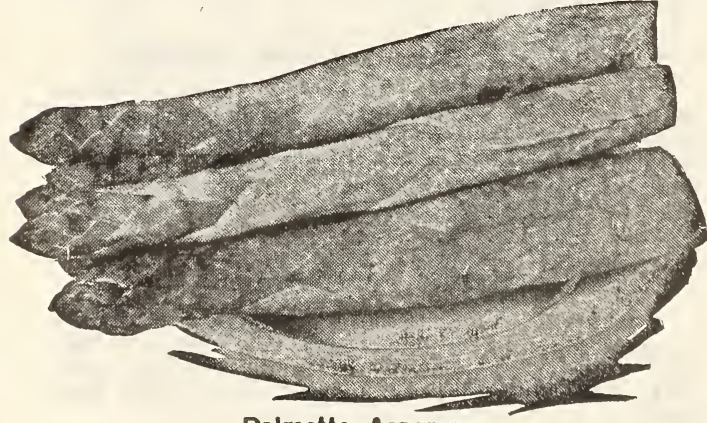

Palmotto Asparague
Barr's Mammoth-Stalks arc very large, frequent. ly an inch in diameter, and liave close round heads. Quick growing, tender and succulent, entirely free rrom woody fibre. Pkt., 10c; 0z., 15c; 1/4 lb., 30c; Ib., 80c.

Columbla Mammoth Whlto-A new variety with white shoots, stays white without earthing up or blanching. Pkt., 10c; 0z., 15c; 1/4 lb., 30c; lb., 80c.

Conover's Colossal-A mammoth variety of vig. orous growth, sending up from 15 to 20 sprouts each year from one to two inches in diameter. Color, deep green and crown very close. Pkt., 5c; oz., 10c; $1 / 4$ Ib., 20c; Ib., 60c.

\section{Asparagus Roots}

Roots of above varieties 25c per doz.; $\$ 1.25$ per 100 , by express, not prepaid.

Prices for larger quantities on application.

\section{Artichoke}

The Globe Artichoke is cultivated for its flower heads, which are used in an undeveloped state, cooked like Asparagus.

Culture-Sow in April in rich soil, and transplant the following spring to permanent beds (in rows or hills) three feet apart and two feet between the plants. Green Artichoke gives a partial crop the first season if plants are started in hot beds in February and March, but the beds will remain in bearing for years. Protect in winter by covering of leaves or coarse manure.

Large Green Globe-Produces large globular heads; scales green shading to purple; best for general use. Pkt., 5c; 0z., 35c; 1/4 lb., \$1.00.

Jerusalem Artichoke-Sometimes used as a table vegetable when pickled, but their greatest value is for feeding stock. Yields 500 bushels per acre. Plant three bushels per arre in rows three feet apart. Cultivate same as Irish potatoes. Greatest hog feed ever known. Tubers, Ib., 25c; 3 lbs., 65c, rosipald. 


\section{Beans-Dwarf or Bush}

Weight of Beans, 60 lbs., per Bushel. Write for prices on larger quantities. We pay postage on one pound lots or better.

Culture-Beans do best on light, warm soil. They do not require heavy manuring. For earliest crop they should be planted after all danger of freezing is past. For succession they shculd be planted every two weeks. Plant two or three inches apart in. rows or two and one-half feet apart. Cover with two inches of soil. Do not cultivate when wet from dew or rain.

Up to the time of blossoming they should have frequent shallow cultivation, but any mutilation of the roots by cultivation after the plants come into bloom is likely to cause the blossoms to blast and so cut off the crop. Beans are very sensitive to cold and wet before they. have sprouted.

\section{Beans-Green Podded Varieties}

Burpee's Stringless Green Pod Bush (Colorado grown) - The earliest green podded Bean. Has absolutely stringiess pods. Of the most superior quality, surpassing all other early Bush Beans, both wax and green podded, in this respect. We advise gardener's to try this Bean. It will be found profitable. Everyone who wants a fine flavored, tender snap Bean for home use should plant this variety. Pkt., 10c; lb., 35c; 2 Ibs., 60c, postpaid.

Extra Early Round Pod Red Valentine-For snaps there is nothing superior to this variety among the green pod sorts and many prefer it to the wax varieties. Vine erect, with dark green leaves; pods medium length, curved, cylindrical, with crease in back, very fleshy, crisp and tender. This variety is very popular in the South. Pkt., 10c; lb., 15 oz., 35c; 2 lbs., postpaid, 60c.

Extra Early Refugee-It is dwarf and compact in growth, the pods are round, solid, tender and of the most excellent quality when cooked for table use or for canning or pickling. Pkt., 10c; lb., 15 0z., 30c; 2 lbs., postpaid, 55c.

Refugee, or 1,000 to 1 -The standard late pickling variety, matures two weeks later than the extra early kinds; very valuable for pickling. Pkt. $10 \mathrm{c}$; lb., 15 oz., 35c; 2 lbs., postpaid, $60 \mathrm{c}$.

Early Long Yellow Six Weeks-A long-podded green variety. Plants strong and vigorous and leaves large; of fair quality. Pkt., 10c; Ib., 15 oz., $30 \mathrm{c} ; 2$ Ibs., postpaid, 60c.

Giant Stringless - Resembles the Improved Valentine in many ways, but the pods are very much larger, and, as a rule, are entirely free from strings and about a neek earlier than the from strings and about a $\pi$ eek earlier than the 2 Ibs., postpaid, 60c.

Black Valentine-Pods perfectly round and straight, although "not quite so early. It has the additional advantage of being suitable both for early and late planting, being extremely hardy. It will withstand early and late frosts which kill other varieties. A most desirable sort for the market gardeners. Pkt., 10c; lb., 15c; 0z., 35c; 2 lbs., postpaid, 60c.

\section{Dwarf or Bush-Wax-Podded Varieties}

Wardwoll's Kidney Wax-This is one of the best known Wax Beans, and is a favorite everywhere, especially with market gardeners. It is one of the -arliest and most productive of beans. The pods are long, very tender, stringless and of most excellent quality. It matures ibout the same time as the Golden Wax. The dry beans are large, kidney shaped, white with dark markings about the eye. A splendid variety for Southeru planting for Northern markets. Pkt., 10c; Ib., 15 oz., 40c; 2 lbs., postpald, 750 .

Pencll Pod Wax-This is the best Black Wax Bean in cultivation. The pods are long, thick and

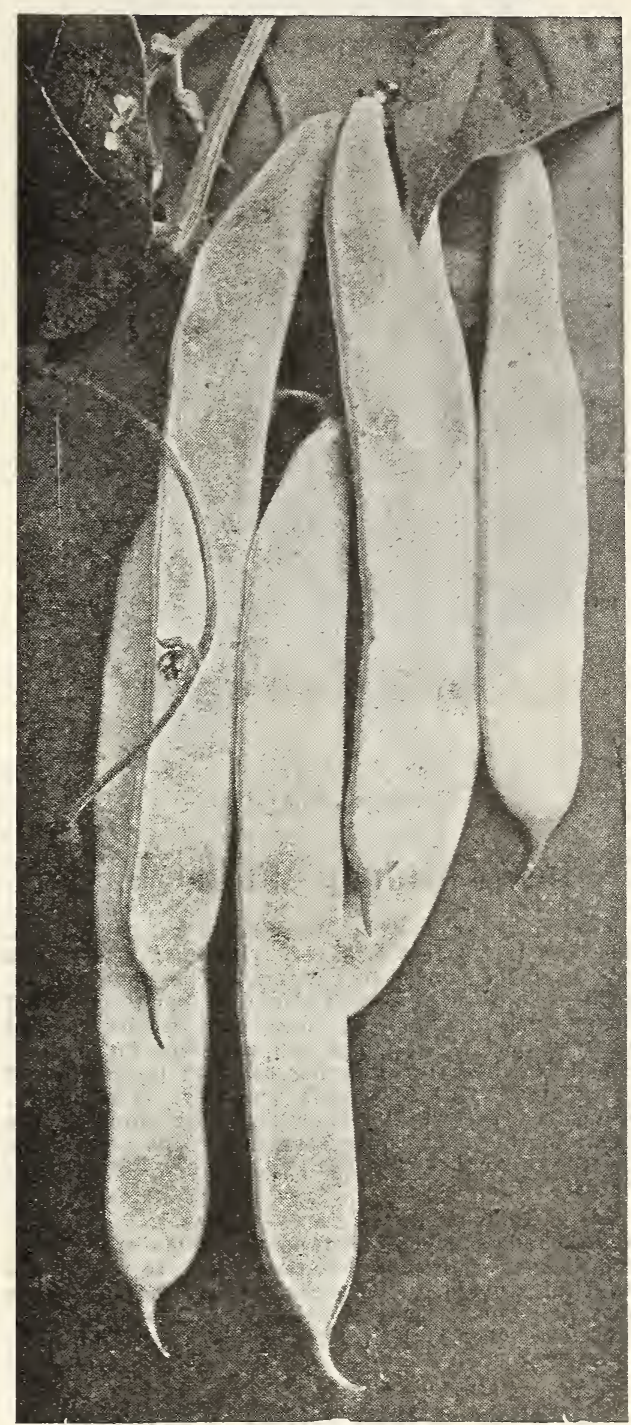

Improved Golden Wax

meaty, and deeply saddle-backed, and entirely stringless. The plant is strictly a bush, growing about fifteen inches high. Seed black. Pkt., 10c; Ib., 15 0z., 40c; 2 lbs., postpaid, $75 \mathrm{c}$.

Improved Golden Wax-The pods are large, long, brittle and entirely stringless, and of a beautiful rich golden wax color. As a Snap Bean it excels every other variety in tenderness and rich, buttery flavor, while as a Shell Beail for winter use it has few or no superiors. It is very prolific of dwarf compact growth. Pkt., 10c; 'b., 15 oz., 40c; 2 Ibs., postpaid, $75 \mathrm{c}$.

Currie's Rust-Proof-An extremely early Black Wax Bean. The very best ITax Bean for market and shipping. Pods straight, rather flat, five inches in length and of a light golden yellow. Very productive. Pkt., 10c; Ib., 15 0z., 40c; 2 Ibs., postpaid, 75c.

Imp. Black Wax-Very early and of fine flavor. Pods about five inches in length, usually curved, quite round, meaty, brittle and stringless. Much better than the old Black Wax or Butter Bean. Pkt., 10c; Ib., 15c; oz., 35c; 2 Ibs., postpaid, 65c. 


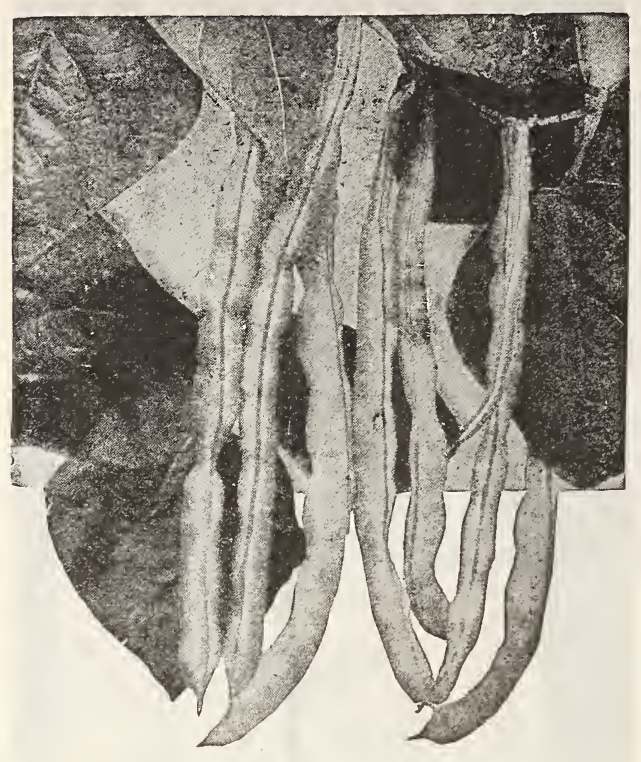

Burger's Pole Bean

\section{Davis Kidney White Wax}

The most productive Wax Bean in cultivation. The vine is rustless and very vigorous, bearing its pods near the center in clusters. The pods are invariably long, white, straight and handsome, and when young are brittle, orisp and tender. Seed kidney-shaped, clear white and excellent for baking. One of the best for shipping as snap beans and of the greatest value as a market variety. The length, uniformity, perfect in shape and fine color of the pods and the clear white seed make this one of the best for canners. Pkt., 10c; Ib., 15 oz., $40 \mathrm{c} ; 2$ lbs., postpaid, $75 \mathrm{c}$.

Early Golden Cluster Wax-Begins to bear early in July and continues until frost. Pods are 6 to 8 inches long, borne in clusters of 3 to 6 , and 8 beautiful golden yellow color, and the flavor is most delicious. Used shelled or as a string bean. Pkt., 10c; Ib., 15 oz., 40c; 2 lbs., postpald, $75 \mathrm{c}$.

\section{Beans-Bush Lima Varieties}

NOTE-Do not plant Lima Beans when the soil is cold and wet, or the seed will rot. The soil must be warm and not too wet. Bear this in mind and there will be no failure with this crop.

Henderson's Bush Lima-The earliest Lima Bean. Is not so large as the Burpee, but much earlier They are very productive and grow in compact form without poles or stakes, and produce large crops of delicious Beans which are easily gathered. What they lack in size they make up in earliness, hardiness and continuous productiveness. They are 10 days ahead of any other Iima Bean. Pkt., 100; lb., 40c; 2 lbs., 700, postpald.

\section{Burpee's Improved Bush Lima}

Earllest, largest and the best of all large LImas. The sturdy bushes are loaded with pods that are truly enormous in size. The lusclous, green beans are larger than any Limas ever known before. It is fully eight to ten days earlier than any other large Limas; will outyield Burpee's Bush Lima by fully one-third as the pods are very much larger, while the beans either green or dry are nearly twice as thick. Postpaid: Pkt., 50; 1/4 Ib., 150: I/2 Ib., 25o; Ib., 40e; 10 Ibs., $\$ 3.50$.

\section{Beans-Dwarf or Bush Miscellaneous}

\section{The White Egg Bean}

This wonderful bean of recent introduction bas proven a most excellent string and shell variety for both green and dry use. The bush or vine makes an enormous growth well filled during the season with large fine beans of a very rich and delicious flavor. Beans are pure white oval shaped and four to five times the size of the common navy beans and yields about three times the amount of dry beans produced by the navies. This bean fills a distinct place in every garden, being quite different from any of the standard varieties. Pkt., 150; lb., 40c; 2 Ibs., 75c, postpaid.

Mexican, Pinto or Chile Con Carne Bean-The popular variety in the West and Southwest; is used exclusively by the Mexicans in the making of chile con carne. Beans speckled, and of medium size. The most profitable Field Bean grown in Colorado. Very prolific. Lb., 15 oz., 25c; 2 lbs., postpaid, 45c.

\section{Beans-Lima}

King of the Garden Lima-One of the most popular Pole Beans ever known. They are vigorous growers, setting the beans early at the bottom of the pole, producing continuously to the end of the season. They are more prolific than the ordinary Lima, bearing profusely in clusters of 4 to 6 with 5 or 6 beans in pod. Pkt., 150; Ib., 45c; 2 lbs. $80 \mathrm{c}$.

\section{Beans-Pole or Running Varieties}

Cut Short or Corn Hill-This is an old and very popular variety for planting among the corn. In some sections it is used almost exclusively. The pods are short, round and very tender. Beans nearly oblong. Pkt., 10c; lb., 35c; 2 Ibs., postpaid, 550.

\section{New Pole Bean-Burger's Stringless or}

White Seoded Kentucky Wonder is decidedly earlier than Kentucky Wonder. Pods very uniform in size, very long, moderately curved, crease backed, dark green in color, extremcly brittle, of excellent quality and free from disease, entirely stringless at all stages of growth. Dry beans excellent for baking in the winter. Pkt., 10c; Ib., 35c; 2 lbs., postpaid, $55 \mathrm{c}$.

White Creaseback-Large, long pods, growing in clusters of from 6 to 12 , if a silvery green of the best quality as snaps. A good corn hill bean. Pkt., 10c; Ib., 30c; 2 lbs., postpald, 550.

Kentucky Wonder or Old Homestead-We can recommend this, one of the earliest and most eatis. factory of all Green Podded Pole Beans, and un surpassed for using in the green state. It is enorm. ously productive; pods hanging in great clusters from top to bottom of the pole. While young the pods somewhat resemble the popular old Refugee. This is the best and most profitable Bean for the market gardener. Pkt., 100; ib., 40c; 2 lbs., postpald, $65 \mathrm{c}$.

Lazy Wifo-One of the best snaps of the later Green Podded Pole Beans. The numerous pods, borne in large clusters, are five to seven inches long, broad, thick, fleshy and entirely stringless. When young they have a rich, buttery flavor which is retained until they are nearly ripe. The dry Beans are excellent for winter use. Seed white. Pkt., 10c; lb., 30c; 2 Ibs., postpald, 55c.

Dutch Caseknifo-Vines moderately vigorous, climbing well but twining more loosely than some and so may be used for a corn hill bean. Pods very long, flat, irregular, green, but becoming creamy white; and of excellent quality, green or dry. Pkt., 100; Ib., 350; 2 Ibs., postpald, 600. 


\section{Beets-Table Varieties}

Culturo-Beets do best in rich, sandy loam, but may be grown in any good soil. The seed should be sown in the spring as soon as danger of frost is passed, in rows from 12 to 30 inches apart. As soon as the plants are well up they should be thinned to 4 or 5 inches in the row. The seed should be covered to the depth of about an inch. It takes about two ounces of seed for 100 feet of row and about 6 to 8 pounds to the acre.

For a succession of young beets during the summer plant every four weeks during spring months. Beets for winter storage should be sown in late summer.

\section{Crimson Globe}

It is just the Beet you want for the table. Beautiful Form. Rich Red Flesh. Exceedingly Tender.

The very dark leaves are small and borne on slender stems which occupy but a small portion of the root; but it is the exquisite tenderness of the flesh and the complete absence of any stringy or woody character that so thoroughly distinguish this Beet. The interior color is very deep crimson throughout, but is ringed or zoned in a most beautiful manner, making it very attractive in appearance. Pkt., 10c; 0z., 15c; 2 oz., 25c; 1/4 Ib., 40c; lb., \$1.25.

Early Blood Turnip-This is a carefully selected strain of this Blood Turnip Beet. It is very early deep blood red and almost round. It is smooth and an excellent forcing variety. Good for main, spring or summer crop, and is a fine keeper. It cooks sweet and crisp and is an excellent beet in every respect. Pkt., 10c; 0z., 15c; 2 0z., 20c; 1/4 lb., $25 \mathrm{c} ; \mathrm{Ib} ., 80 \mathrm{c}$.

Edmond's Blood Turnlp-Handsome round shape, skin very deep, blood red color, flesh very dark and exceedingly sweet and tender. Very regular and of good size. Make excellent bunch beets. Pkt., 100; 0z. 15c; 2 oz., 20c; 1/4 Ib., 250 ; tb., 800 .

Crosby's Early Egyptian-One of the earliest and best on the market. It is nore globular than the Early Egyptian. Especially good for market gardeners. Pkt., 100; 0z., 150; 2 0z., 200; 1/4 lb., 300; Ib., 90c.

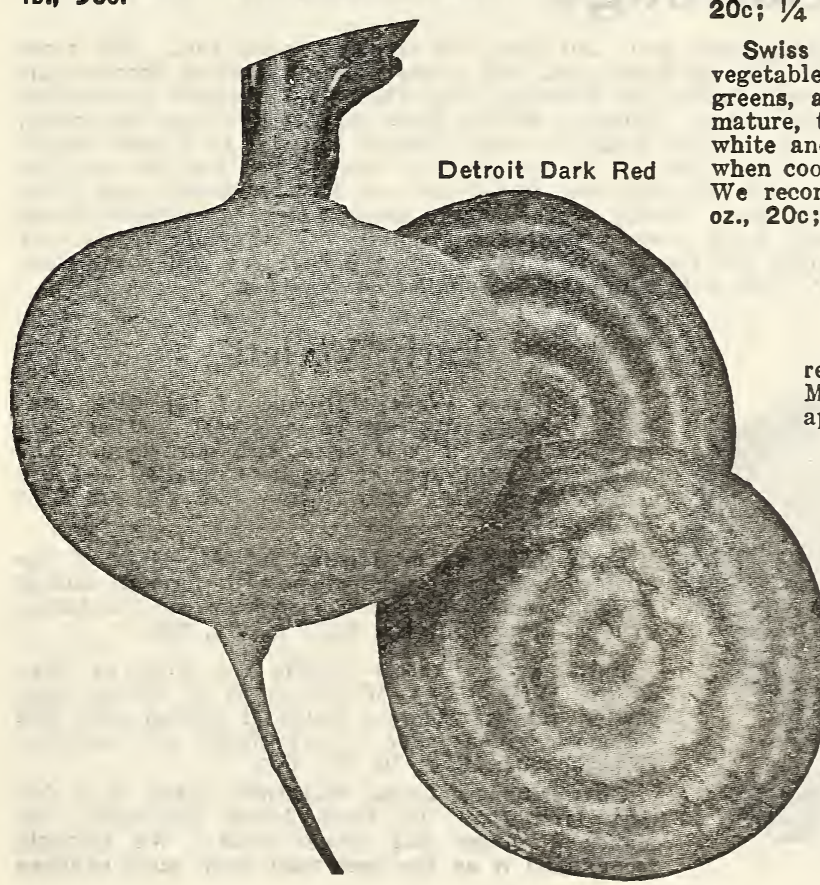

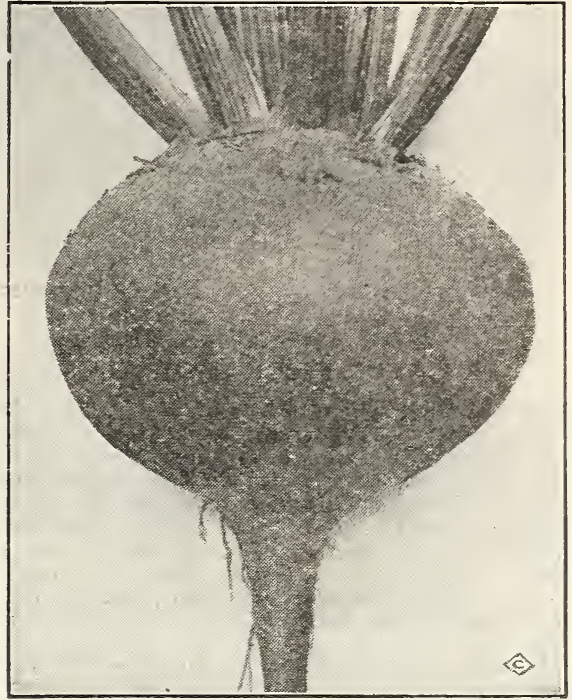

Crimson Globe

Extra Early Egyptlan-An extra early turnipshaped variety; has small t,ups and grows quickly. The flesh is in alternate rings of white and red. Pkt., 100; 0z., 15c; 2 0z., 200; 1/4 lb., 250; lb., 800. Dotroit Dark Rod-A choice strain of dark red turnip beet of globular to oval shape with smooth roots and small tops. Skin is blood red, zoned with light shsies, tender and sweet. Fine for market and canning. Pkt., 50; 0z., 100; $1 / 4$ lb., 35c; Ib., $\$ 1.00$.

Ecllpso-This is as early as the Egyptian, but is more desirable owing to its clobe shape, mooth. ness and regularity. It has a small firm top, is very sweet, fine and of dark red color. Pkt., 100; 0z. $15 \mathrm{c} ; 2$ oz., 20c; $1 / 4$ lb., 25c; lb. 800 .

Long Blood Red-The old standard variety for table and cattle. It is the best drouth resister of all; color deep red, flesh very sweet. Grows entirely under the ground. Pkt., 10c; 0z., 150; 2 0z., c; $1 / 4$ Ib., 25c; Ib., 80c.

Swiss Chard, or Foliage Beet-This is a distinct getable from the common veet, much superior for and is ready for use much earlier. When the plants form bro:ld, flat and beautifully wax-like stems, which are very delicious we recommend this beet. Pkt., 10c; 0z., 15c; 2 We recommend this beet. Pkt.
z., 20c; $1 / 4$ lb., 30c; lb., 90c.

\section{Sugar Beets and Mangel Wurzels}

Culture-Both Mangels and Sugar Beets require deep, well enriched soil. Sow in May or June in rows 18 inches to 2 feet apart and 3 to 8 inches in the rows. Young plants may be transplanted to fill up vacancies. As soon as frost occurs dig the crop. Five to six pounds are required for an acre.

\section{SUGAR BEETS}

Kloin Wanzleben-This is the variety so extensively planted for sugar factories. Rich in sugar, crisp and a heavy yielder. Grows from 10 to 15 inches in length and from 4 to 6 inches in diameter at base of leaves, tapering gradually under the surface of the ground. This beet does not grow above the surface. Yields all the way from 10 to 30 tons per acre and is very profitable for feeders of cattle, hogs or sheep. Pkt., 10c oz., 15c; 2 oz., 20c; $1 / 4$ ib., 25c; Ib., 750. 


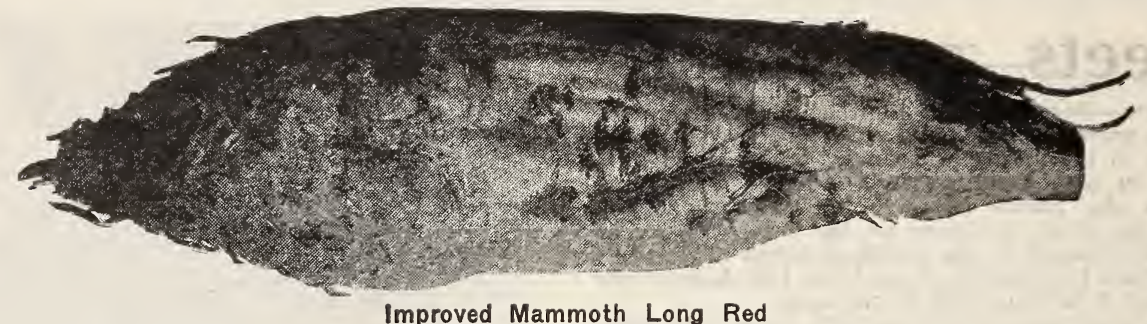

\section{Half Sugar Mangel FOR STOCK FEEDING}

Giant Feeding Sugar Beet or Half Sugar Mangel - Especially desirable for stock feeding, affording not only a very large crop much easier to harvest than other sorts but also having higher nutritive value, being especially rich in sugar. On account of growing partly out of the ground and the long ovid shape the crop can be harvested and stored easily and at less expense than any other root crop. Prepaid parcel post: Pkt., 5c; 1/2 Ib., 25c; Ib., $45 \mathrm{c}$; 10 lbs., $\$ 4.00$.

Lane's Improved Imperial Sugar-Will yield almost as much as the mangels, and contains from 12 per cent to 15 per cent sugar. Roots long and smooth and very regular in size tapering very evenly, and, as a rule are free from fibrous roots. Pkt., 10c; 0z., 15c; 2 0z., 20c; 1/4 lb., 25c; Ib., 75c.

Improved Mammoth Long Red-Our stock is a great improvement on the old variety. Roots very large, uniformly straight and well formed; color deep red; roots solid; tops small. Will yield 50 tons per acre with ordinary cultivation. If you want a large crop of Mangels of good quality don't fail to try this sort. Should be grown in deep, loose soil. By parcel post, prepaid: Pkt., 5c; $1 / 2$ Ib., 25c; Ib., 45c; 10 lbs., $\$ 4.00$.

Golden Tankard-The most satisfactory variety to plant for stock. Early, hardy and a heavy cropper. Flesh yellow; tops and neck very small; easily pulled; especially relisned by sheep and cows. Prepaid: Pkt., 5c; $1 / 2$ lb., 25c; lb., 45c; 10 lbs., $\$ 4.00$.
Yellow Globe Mangel-Very similar to the Red Globe except in color. Pkt., 10c; 0z., 20c; $1 / 4 \mathrm{lb}$. 60c; Ib., \$1.25.

Giant Eckendorf-The roots are smooth long and cylindrical in shape, very much like the tankard mangels. They are very heavy, weighing up to 15 and 20 pounds each. The flesh is firm, crisp, and solid white in color and of high feeding value. This variety is easily harvested a large proportion growing above ground. By parcel post, prepaid: Pkt., 5c; 1/2 lb., 25c; lb., 45c; 10 lbs., $\$ 4.00$.

Danish Mangel "Sludstrup".-Sludstrup is a long, reddish yellow root, but not so long as the Mammoth Long Red. It grows more above the ground and is very easily harvested; the size, like all other varieties, depends entirely upon circumstances. They frequently grow to a size weighing from 15 to 20 lbs. each. By parcel post, prepaid: Pkt., 5c; 1/2 lb., $25 \mathrm{c}$; lb., $45 \mathrm{c}$; 10 lbs., $\$ 4.00$.

\section{Broccoli}

Should be treated the same as Cauliflower, which it resembles. In fact, it is practically a coarse Cauli. flower; more divided in the liead, grows larger and taller and is hardier and easier to grow. Plant and cultivate the same as Winter Cabbage or Kale.

Early Large White-The best variety. Heads white and large. Pkt., 5c; oz., 40c; 1/4 lb., \$1.25; Ib., $\$ 4.00$.

Purple Cape-Good, large heads, which are tinged with purple. Pkt., 5c; 0z., 35c; 1/4 lb., \$1.00; lb., $\$ 3.50$.

\section{PURE SELECTED Cabbage HIGH GERMINATION}

Culture.-Cabbage requires a rich, moist heavy soil, and deep and frequent cultivation. For extra early use the seed may be sown in the fall during September, and young plants protected through the winter in cold frames, or sow the seed during January or February, very thinly and shallow in hot-beds When the young plants have reached sufficient size, gradually harden them off by admitting air freely. Transplant to the open ground as soon as the ground works up well; prepare the soil to a good depth, making it loose and fine. Plant one by two feet and cultivate every two weeks. For late use sow the seed in the fine soil during May or June. Sow the seed very thinly and not over one-fourth inch deep. The plants become weak and slender when sown thickly. When large enough set out fifteen inckes apart in rows three feet apart and cultivate every week. Another easy method is to plant five or six seeds in a hill where they are to remain; after the plants have made three or four leaves pull out all but the strongest plant. When insects appear, dust with slug shot or similar preparation.

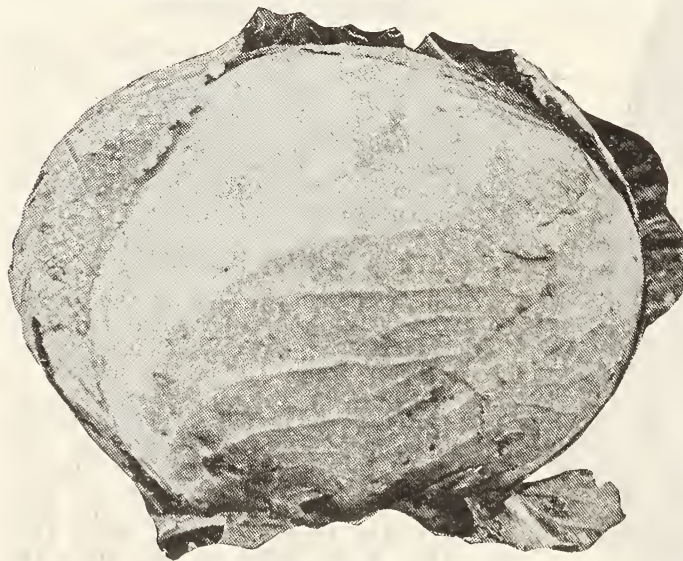

All Head Early

\section{Early Varieties}

Early Jersey Wakefield-One of the best extra early varieties. As sure as it is early. These two qualities make it a favorite with gardeners. The heads are solid and of excellent quality and are capable of resisting early frosts. Pkt., $5 \mathrm{c}$; 0z., 25c; $1 / 4$ Ib., 80c.

Early Etampes or Earliest of All-One of the earliest cabbages, producing well formed conical heads of remarkable size for such an early maturing variety. Pkt., 5c;0z., 25c; 1/4 Jb., 80c.

Extra Early Express-While not quite so large as the Early Jersey Wakefield, it is several days earlier. It has compact hearls of conical form and yellowish green color. Very dwarf and uniform. Pkt., 5c; 0z., 25c; 1/4 lb., 80c.

Charleston or Large Wakefield-This is a few days later than the Early Jersey Wakefield, but makes a larger and firmer head. We strongly recommend it as the best man crop early cabbage 


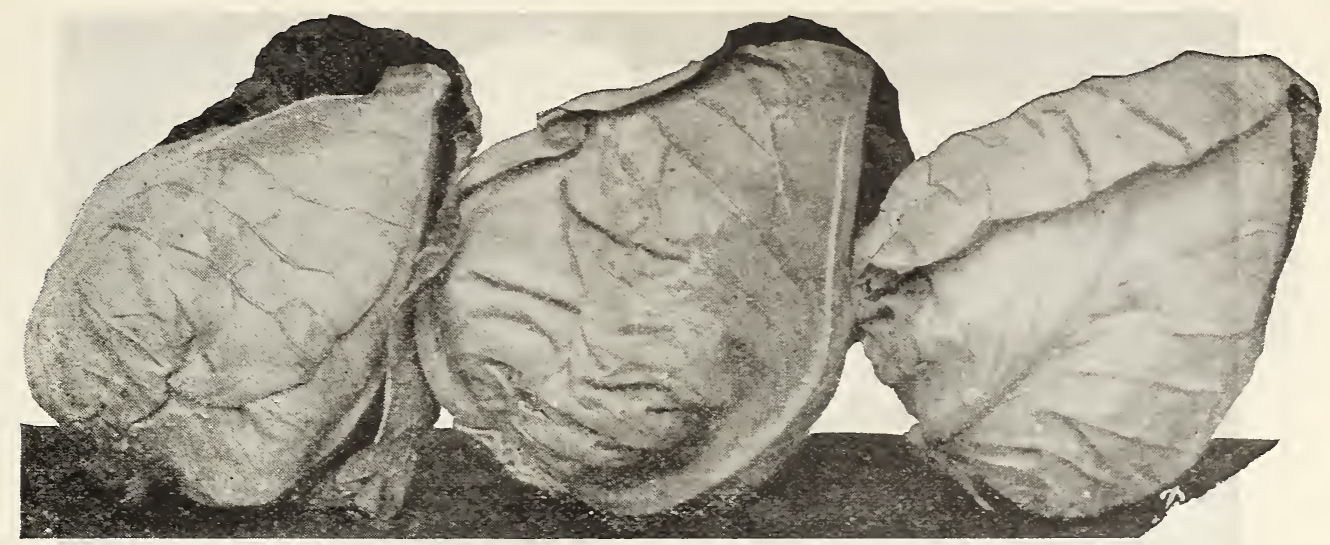

Early Winningstadt

grown, for the home garden and market. Our seed of this is grown from a special selected stock. Pkt., 5c; 0z., 25c; $1 / 4$ lb., 80c.

Early Winningstadt-A distinct second early sort and one of the best for general cultivation. Being very hardy, it is therefore less subject to wet or drouth, insects or disease. A sure-heading variety, giving entirely satisfactory crops. The heads are uniform in size, conical in shape and very solid. It is valuable for early use, and on account of its solidity and short, thick leaves, it makes also a good winter cabbage. Pkt., 5c; 0z., 25c; 1/4 Ib., $80 \mathrm{c}$.

Early Spring-This is unquestionably the earliest of the flat head cabbages. A type which is preferred by many over the pointed heads. This is nearly as early as the Wakefield. The heads having few outside leaves enables me to plant them very close together. It is round in shape, slightly flat. tened, and solid even before the cabbage is matured. Pkt., 5c; 0z., 25c; 1/4 lb., 80 c.

\section{Copenhagen Market Cabbage}

The best large round-head early cabbage in cultivation. The heads are very solid, with small core and of the finest quality, all maturing at the same time.

The plants are short stemmed. The leaves are light green, saucer-shaped and tightly folded, which permits closer planting than is usual with varieties of similar size. This is the most valuable early cabbage for market gardeners yet introduced. Do not fail to include it with your order. Our seed is imported direct from the orignators. Pkt., 5c; 0z., 35c; 1/4 lb., \$1.25.

Allhead Early-Deep flat heads. Very uniform in size and color. The earliest of all extra large cab. bages. The leaves are combact, so will stand close planting. A good keeper, desirable for both early fall and winter. Pkt., 5c; 0z., 35c; 1/4 lb., $\$ 1.25$.

\section{Glory of Enkhuizen}

A Very Valuable Early Sort-For full description and price, see Specialties, page 7.

SECOND EARLY OR SUMMER VARIETIES

All Season-Ileads very large, round, solid, and of fine quality, keeping as weil as the winter sorts. Plants very vigorous, but sure heading. Remarkals: for its ability to stand the hot sun and the dry weather. Pkt., 5c; 0z., 25c; 1/4 lb., 80c.

Early Dwarf Flat Dutch-A standard variety for planting in the South and a great favorite with Texas market gardeners. One of the best heat resisting kinds, reaching a perfect state of develop. ment in the hottest weather. The plant is short stemmed, upright, having coinparatively few short leaves the rows can be set close together. Heads large, solid, crisp and tender, maturing with the early Summer. Pkt., 5c; 0z., 25c: 1/4 lb., 80c.

\section{Late and Winter Varieties}

Surehead-(Selected Stock)-The heads are large, round, very solid, tender and rich, with very few outer leaves, being nearly all solid, compact head; but the most wonderful feature of the Surehead Cabbage is its ability to withstand the drought. Flavor sweet, keeps well and is a good snipper. Pkt., 5; 0z., 25c; 1/4 lb., 80c.

Large Late Flat Dutch-An extra large late winter variety, which has no superior. Market gardeners plant largely of this variety and realize a good profit. On account of its extra large size it never fails to bring high prices in the market. It is of sureheading stock, has short stem, and is a compact grower. Pkt., 5c; 0z., 25c; 1/4 Ib., 80c.

Danish Ball-Head-Short stemmed. A strain selected from the famous Danish Ball-Head Cabbage that has become one of the best and most popular sorts both for home and market growing. The heads are very large, round, and solid as bullets. The inside leaves are white, crisp and tender. On account of their solidity, cabbages of this variety will outweigh those of other varieties of the same size. It is short stemmed, strong and vigorous. Will keep and ship well. Pkt., 5c; oz., 35c; $1 / 4 \mathrm{lb}$.

\section{$\$ 1.25$.}

Danish Ball Head, or Hollander Cabbago-This variety, known as Ball Head, has been selected and brought to perfection for more than fifty years by Danish gardeners, who grow it almost exclusively for winter use. Bears shipping well and keeps far into the spring. Heads round as a ball, extremely solid and fine-grained: Excellent cooking qualities. Takes full season to make matured heads. Order the genuine Hollander of us. Pkt., 5c; oz., 350; $1 / 4$ Ib., \$1.25.

Promium Late Flat Dutch-Heads large, bluishgreen, round, solid, broad and fiat on top, and often tinted with reddish brown after being touched with frost; they open white and crisp, are tender and well flavored. One of the very best keepers. Pkt., 5c; 0z., 25c; 1/4 lb.. 80c.

Large Late Drumhead-This popular Cabbage never fails to make a remarkably fine, solid, large head, with few outer leaves. it is strong, vigorous grower, ripening late. It is a first-class main crop variety very uniform in sizf and color. Pkt., 5c; 0z., 25c; 1/4 it $80 \mathrm{c}$

We never suiostitute unless requested to do so; if wo are out of what ynu order we refund you: money.

We can Supcly Cabbage Plants in Season

Marblehead Mammoth Drumhead-The largest Ciablage known. Under good cultivation acres have been grown where the hearis would average 30 pounds each. Is late in maturing and the seed should be planted earlier than that of most sorts. Pkt., 5c; 0z., 25c; 1/4 lb., 80c.

Mammoth Rock Red-This is without question the finest surest heading rad Cabbage ever offered to the people. Large size. F'kt., 5c; 0z., 25c; 1/4 Ib., 80 c. 


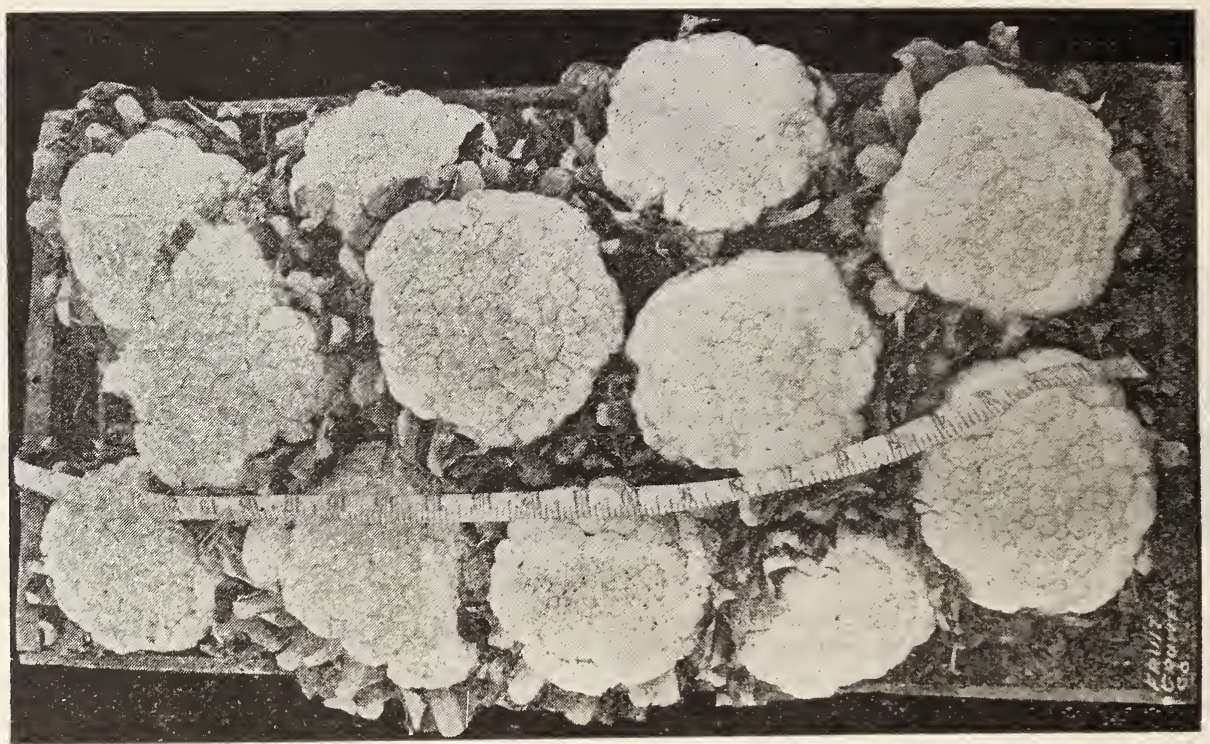

Improved Early Snowball

\section{Cauliflower}

\section{Fine Danish Grown Stock}

Culture.-The culture of cauliflower is much the same as that of cabbage. It does not make a good summer crop, however, as it will not head up well in hot weather. It is especially popular as a fall and winter crop, and with market gardeners proves a profitable crop, owing to the scarcity of good market vegetables when cauliflower is at its best. It delights in a rich soil and abundance of water. By sowing the early varieties in a hotbed in February, March, or later, in a cold frame, fine heads can be obtained quite early. For a later supply sow seed in a prepared bed in May, choosing a cool, moist place. When large enough, transplant, making the rows about two and a half feet apart and eighteen inches betwen plants. Transplanting should be done in moist weather. In dry seasons the crop must be watered.

Ebbert Seed Co.'s Improved Early SnowballUnquestionably the earliest maturing strain of the true short leaved Snowball type of Cauliflower. Successful gardeners, after trials extending over many years, have pronounced this by far the best Cauliflower ever introduced. The outer leaves are short. Its compact habit of growth renders it a very profitable variety to force under glass, and it does well for late planting, as well as for early crops. It is a sure header. Our stock cannot be excelled in quality. Pkt., 10c; 1/8 0z., 30c; 1 oz., $\$ 2.00$.

Extra Early Dwarf Erfurt-This variety will stand the test with any other extra early sort. It is very dwarf in habit, producing pure white heads of great solidity and finest quality; quite desirable for forcing or for planting in open ground. For a general all-around market garden variety we can highly recommend the Erfurt strain. Pkt., 25c; $1 / 4$ oz., 75c; 0z., $\$ 2.50$; 2 oz., $\$ 4.50 ; 1 / 4$ lb., $\$ 8.00$.

Extra Early Paris-This is a well known standard French variety, producing very early, good-sized pure white heads, which are tender and delicious. Pkt., 5c; 1/2 0z., 25c; oz., 50c; 1/4 lb., \$1.50; lb., $\$ 6.00$.

Dry Weather-(Also known as Danish Giant)Especially adapted to resist arought. Reaches perfection when ordinary sorts fail. This new strain originated in Denmark, but has been fully tested in America, producing large, soiid, pure white head, maturing a little later than Eariy snowball. It is in all respects a first-class Cauliflower, and is especially adapted to dry situations and to resisting droughts. Like all other Cauniflowers it requires manure and culture; but it will succeed with less rainfall than any other variety. Pkt., 10c; 1/8 0z., 30 c; 1 0z., $\$ 2.00$.

\section{Brussels Sprouts}

\section{(Cultivate same as Cabbage).}

The plants are very hardy and grow from two to three feet high, bearing a large mass of leaves at the top. The sides of the main stem are covered with three or four dozen small cabbage heads, which are broken off and cooked the same as cabbage.

Improved Half Dwarf-The standard variety grows two or three feet high and the stem is well covered with small, firm, round sprouts. Pkt., 5c; 0z., $15 \mathrm{c} ; 1 / 4$ Ib., $45 \mathrm{c} ; \mathrm{Ib} ., \$ 1.50$.

We never substitute unless requested to do so: if we are out of what you order we refund your money.

We can Supply Cabbage Plants in Season. 


\section{Celery}

Culturo-Celery seed is slow to germinate-sow thinly and cover lightly, and keep constantly moist. Sow the seeds early in a hotbed or cold frame. As soon as the plants are three inches high, transplant in a prepared border, setting them four inches apart. When grown six inches, and fine, stocky plants. et in richly manured, deep soil, in rows three and a half feet apart and about nine inches from plant to plant. Water, if dry weather follow: transplanting. During the next two months all the attention that is required is to keep down the weeds. Afterwards, earth up a little, and continue doing so at intervals until only the tops of the leaves are visible late in the autumn. Never hoe up the earth when plans are wet.

Golden Self Blanching-This is the standard celery for early use. Critical gardeners generally depend upon our stock to produce their finest early celery. It is excellent for the home garden. The plants are of medium size, compact and stocky, with yellowish green foliage. As they mature the inner stems and leaves turn beautiful golden yellow so that blanching is effected at a minimum expenditure of time and labor. Its handsome color, crispness, tenderness, freedom from stringiness, and fine nutty flavor have established it as a superior first early sort. Pkt., $5 c$; $1 / 2$ oz., $40 \mathrm{c}$; oz., 65c; 2 oz., $\$ 1.15$; $1 / 4$ lb., $\$ 2.00$; Ib., \$7.50.

White Plumo-Has been much in demand as a market sort on account of its very attractive appearance and requiring a very short time for blanching. It is suitable also for the home garden. Pkt., 5c; 0z., 35c; 2 oz., 60c; 1/4 lb., \$1.00; lb., $\$ 3.50$.

Giant Pascal-This is a green leaved variety developed from the Golden Yellow Self Blanching and is an excellent sort for fall and winter use. It blanches to a beautiful yellowish-white color, is very solid and crisp, and of a fine nutty flavor. Especially recommended for the South, where it is prized more than any other kind. Pkt., 5c; oz. $30 c ; 2$ 0z., 55c; 1/4 Ib., 90c; lb., $\$ 3.00$.

Celeriac, or Turnlp-Rooted Celery-Produces large turnip-like roots, which keep well for winter use; it is highly esteemed either cooked for flavoring soup or sliced and used as a salad.

Large Smooth Prague-This is unquestionably the largest and best Celeriac in existence. Pkt., 5c; oz., 25c; 1/4 Ib., 80c.

\section{Carrots}

Culture-Carrots grow best in rich, deep, sandy loam, well pulverized and deeply cultivated. For early crop sow as soon as the ground can be worked, and for later crops, from the beginning to the end of May, in rows 15 inches apart and half an inch deep. Thin out the young plants to five inches and keep the surface open by frequent use of the hoe.

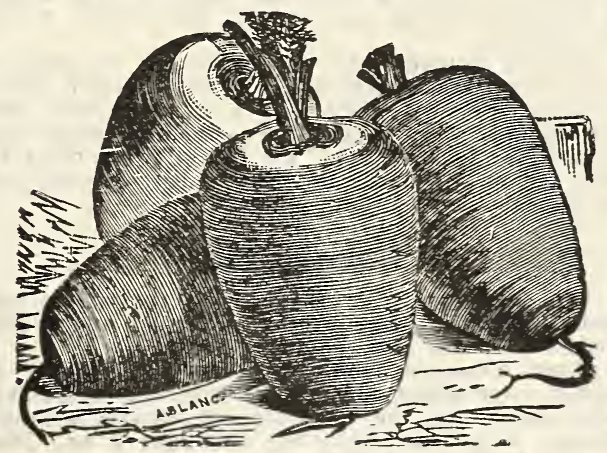

Ox Heart Carrots

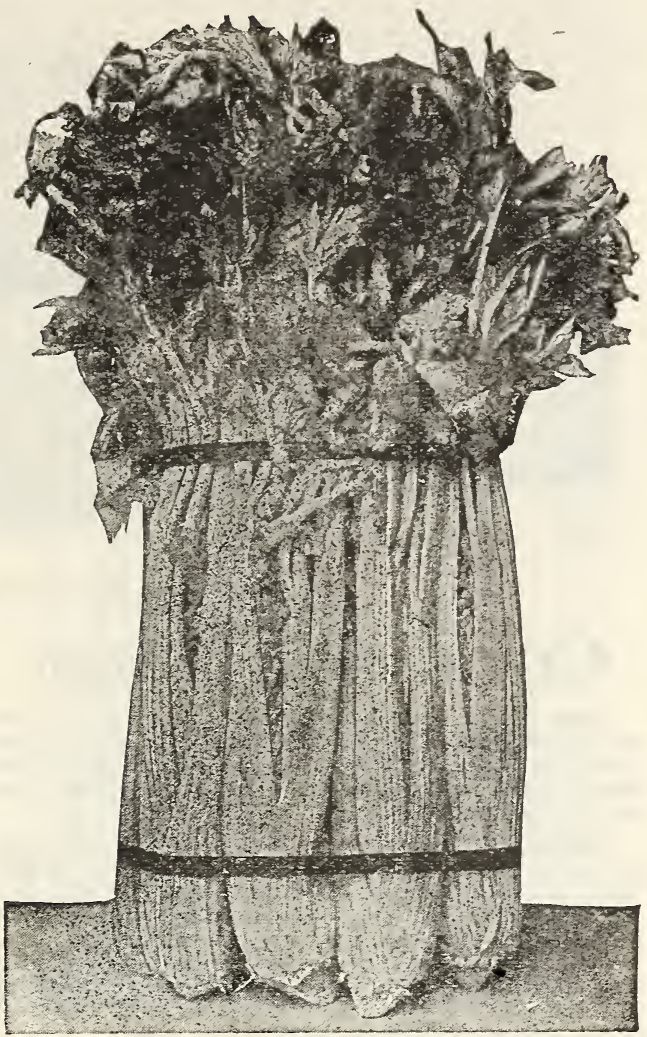

Golden Self-Blanching

Chantenay or Model-One of the best early Carrots in cultivation. In shape it is midway between the Half-Long Nantes Stump-Rooted and the Guerande or Oxhart varieties, nearly equaling the former in length and having the broad shoulder and tapering root of the latter. Its color is orangered; the flesh crisp and tender. Very early and a heavy cropper. A carrot which market gardeners should plant for their main early crop. Pkt., 100; oz., 15c; 2 oz., 20c; 1/4 lb., 30c; Ib., 90c.

Danvers Half-Long-The best variety for general purposes and the most largely used, not only for stock raising, but for table use as well. The perfect type is about eight inches long and about two and $a$ half inches wide at the shoulder, tapering to a sort of half point at the bottom. Color is a bright orange-scarlet. It is a very heavy cropper. Pkt., 5c; 0z., 10c; 1/4 Ib., 30c; Ib., \$1.00.

Early Scarlet Horn-The roots grow three to four inches long and are decidedly stump-rooted. They are fine-grained and of good flavor. Pkt., 5c; oz., 10c; 1/4 Ib., 30c; lb., \$1.00.

Nantes Half-Long, Early-The sweetest of all

Carrots, is of good shape and size. The leaves are fine, the roots are almost cylindrical, very smooth and grow about six inches long; the flesh is entirely red, very sweet and almost entirely without a core. Pkt., 5c; 0z., 10c; 1/4 lb., 30c; lb., \$1.00.

Oxheart, or Guerande-Beautiful shape and color. The roots generally attain four or five inches in diameter. Quality first rate, very tender, with almost an entire absence of core. This is the market gardener's favorite. Pkt., 5c; oz., 10c; 1/4 Ib.. 30c; Ib., \$1.00. 


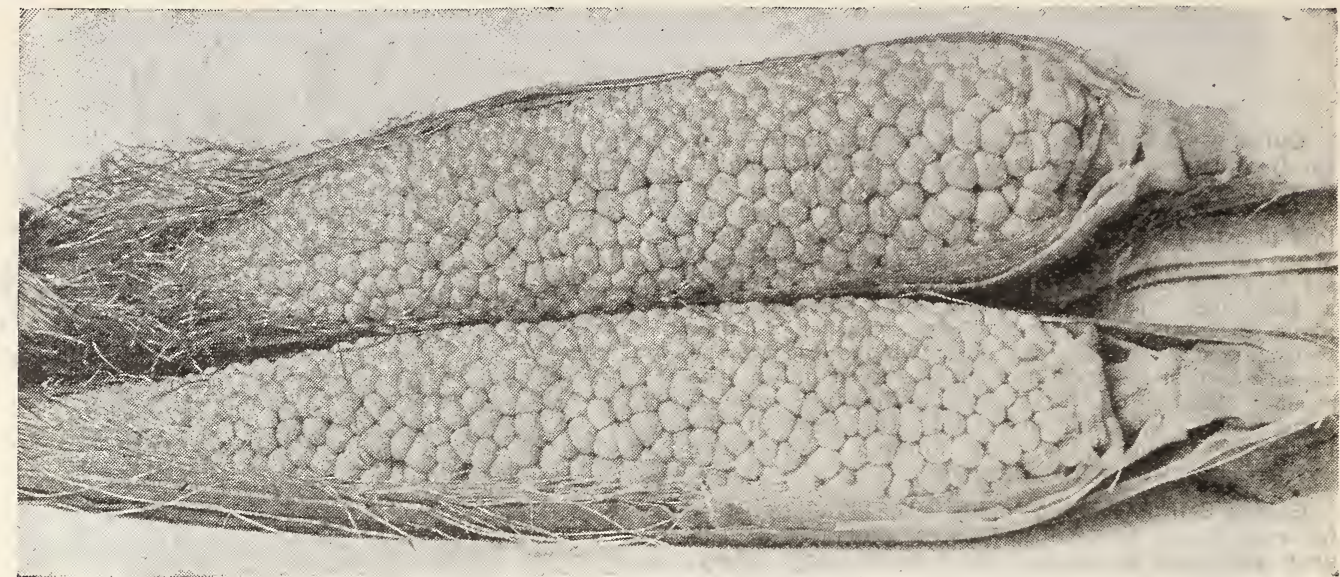

Country Gentleman Corn

\section{Corn-Sweet or Sugar}

Even a small garden has room for a row or two of Sweet Corn. If you have room for only a few rows be sure that you try Golden Bantam for early and Country Gentleman for late. These two are wonderfully delicious.

Culturo-The Sweet or Sugar Corn varieties being liable to rot in cold or wet ground, should not be planted until May, or when the soil has become warm and dry. For a full supply for the table during the entire season plant every ten days or two weeks until the last week in July, in hills $2 \times 3$ feet apart for the early kinds, $3 \times 3$ feet for the large late sorts. Some piant in rows $3 \frac{1 / 2}{2}$ feet apart and eight inches apart in the rows.

\section{New Golden Bantam}

\section{THE EARLIEST OF ALL SWEET CORNS}

This new Sweet Corn is described as the tenderest, sweetest and best ever-green Sweet Corn in existence. It produces strong, sturdy stalks, growing about four feet high. Each stalk produces from four to five ears 5 to 6 inches long, having eight rows of sweet kernels. On account of its firm texture it can be planted earlier than any other variety of Sweet Corn and is less apt to be bothered by worms. Don't fail to have some of this splendid corn in your garden next year. Pkt., 10c; Ib., 35c; 2 lbs., 60c, postpaid.

Extra Early Adams-This is not a true Sweet Corn, but produces ears well filled with tender white grains. It is very early and on account of its hardiness and hard, rours grain, it can be planted much earlier than Sweet Corn. Pkt., 10c; lb., 25 c; 2 lbs., 40 c; postpaid.

Peep O'Day - A new variety of extraordinary earliness and superior sweetness: equalling the larger and later varieties. Wonderfully productive owing to the fact that the stalks bear from 2 to 3 ears each. The originator clains for this variety that it sometimes yields almost double as much as other sorts. Postpaid: Pkt., 5c; 1/2 lb., 15c; Ib., 25c; 10 Ibs., 2.25.

Early Evergreen-An improvement over the Stowell's Evergreen in that it comes ten days earlier and produces almost as large ears. The grains are pure white, very deep, tender and luscious. For second early or main crop we highly recommend it. Pkt., 10c; lb., 35c; 2 Ibs., 60c, postpaid.

Howling Mob - The stalks are usually about 5 feet in height and produce early in the season two splendid ears to $a$ stalk. The ears are 7 to 9 inches in length and are well covered with a heavy husk, affording protection from the green worms which so often are destructive to early varieties. There are 12 to 24 rows of good sized white kernels. Pkt., 10c; Ib., 35c; 2 Ibs., 60c, postpaid.

Country Gentleman, or Shoe Peg-The plump pearly white kernels are of great depth, most delicious, and the flavor will delight an epicure. The cob is small, the ears ar: of good size and are generally produced two or three to the stalk. The grains are set on the cob in a zig-zag manner which makes it very difficult for worms to damage it to any extent. This corn is undoubtedly the very best of the medium late varieties and grown more extensively in Colorado and other parts of the country than any variety of Sweet Corn. We can furnish both Colorado grown and Eastern grown stock. Pkt., 10c; lb., 30c; 2 lbs., 50c, postpaid.

Stowell's Evergreen-This standard main crop variety excels all other late sorts in sweetness and productiveness. It is the popular Sweet Corn for canning, for marketing and home use. It has the advantage of remaining green and tender for a long time. The ears are very large; we have seen them 10 to 11 inches long. This will outsell the common varieties two to one. Besides it has the finest foliage for a fodder crop. We are sure our extra select Stowell's Evergreen will bring you good results. Postpaid: Pkt., 5c; 1/2 lb., 15c; Ib., 25 c; 10 Ibs., $\$ 2.25$.

White Australian-A white deep meated table Corn; very hard, will mature in 85 days, bears two or three fair sized ears to the stalk; tender and a good standby through the summer months and up to the time of the ripening of the Sweet Corns. Pkt., 10c; Ib., 30c; 2 Ibs., 50c, postpaid.

\section{Pop Corn}

Whito Rico-A popular and productive varlety. The kernels are fine, white and pointed, and the ears from 4 to 5 inches in length, and from 1 to $11 / 4$ in diameter. Lb., 15c; 2 lbs., 25c; 10 lbs., $\$ 1.00$. If ordered sent by parcel post, add $5 \mathrm{c}$ per pound for postage.

Queen's Golden-This is one of the handsomest popcorns. It surpasses all in yield, size and color. It pops prefectly white and a single kernel will expand nearly an inch. Often produces from four to six ears to the stalk. Lb., 15c; 2 lbs., 25c; 10 lbs., $\$ 1.00$. If ordered sent by parcel post, add $5 \mathrm{c}$ per pound for postage.

\section{Corn Salad}

This small salad is used during the winter and spring months as a substitute for lettuce and is also cooked and used like spinach.

Green Etampes, Small Seeded-Sow thickly in drills, cover slightly first of autumn, and sprinkle with straw on the approach of severe weather. Height, 4 inches. Pkt., 5c; oz., 20c; 2 oz., 350: $1 / 4$ Ib., 55c: Ib., \$1.75. 


\section{Colorado Grown Cucumber Seed}

OUR SEED IS GROWN BY OURSELVES FROM OUR OWN THOROUGHBRED STOCKS.

The cucumber is one of the most popular of vegetables and with a little care can be grown to perfection in any part of the United States. Every family so situated should be supplied from its own garden, as the fruit is much better when gathered fresh from the vines than obtained from the market, which is usually in a more or less wilted condition. One of our leading specialties is the growing of cucumber seed. We plant several hundred acres of the leading standard varieties for seed purposes every season.

Culture-Cucumbers thrive best in a warm, moist, rich, sandy loam, manured, and should not be planted in open ground until the weather is settled and warm, as otherwise they will not thrive. Plant in hills three to four feet apart each way, thinning to three or four of the strongest plants after danger from insects is past. For a very early crop, the seed may be planted in small berry boxes in the hotbed or the window in the house during the early spring and transplanted to the open ground when all danger of frost is past. When setting them out, the boxes can be easily cut away without disturbing the roots.

The young plants are liavle to attack from the striped cucumber beetles which are numerous in some parts of the country. These insects may be kept off by frequent dusting with air-slacked iime soot or sifted ashes mixed with dust; care should be taken not to use too much of the above materials, for if used too freely they will injure the vines. The cucumbers should be gathered as soon as they reach a marketable size.

Boston Pickling (or Green Prolific)-A distinct variety. A favorite with pickle growers and commercial gardeners, and good for table use. Quite productive; fruit small, uniform in size. Pkt., $5 \mathrm{c}$; oz., 10c; 2 oz., 15c; 1/4 lb., 25c; lb., 90c.

Chicago, or Westerfield Pickling-Grown extensively for the large packing establishments. Fruit medium length, pointed at each end with large and prominent spines; color a decp green. Pkt., 5c; 0z., $10 c ; 2$ oz., 20 c; $1 / 4$ lb., 30 c; lb., \$1.00.

Early Cluster-Fruits small and prickly, borne in clusters. Early and productive. Pkt., 5c; 0z., 10c; 2 oz., 15c; 1/4 Ib., 25c; !b., 90c.

Early Frame, or Short Green-An excellent sort both for table and pickling. Fruit straight, hand some, smaller at each end, bright green, flesh tender and crisp and makes fine piciles. Our stock is very superior. Pkt., 5c; 0z., 10c; 2 oz., 15c; 1/4 lb., 25c; lb., 90c.

Everbearing-Claimed to even excel the Early Russian in its everbearing character, producing fruit in immense quantities, whether fruit is allowed to ripen on the vine or not. Fine for table or for pickles. Cucumbers short and thick. Pkt., $5 \mathrm{c} ; 0 z$., $15 c ; 2$ oz., 25 c; $1 / 4$ lb., 40 c; ib., \$1.50.

Snow's Pickling-An early maturing, very small, dark green cucumber; symmetrical square ended and very popular with growers wanting an ideal pickle. Ready for use in 50 days. Postpaid: Pkt., 5c; oz., 15c; 1/4 lb., 25c! 1/2 lb., 60c; Ib., \$1.00.

\section{Improved Long Green}

Best and most popular variety for general use. Is vigorous and productive and forms fruit fit for use almost as early as the shorter varieties. Grows from +12 to 16 inches or more in length, skin deep ereen, flesh solid, crisp and of fine quality. Excellent for pickles; also the mature fruits are sometimes used for making sweet pickles. Our strain of this valuable sort is unsurpassed, being carefully selected from the best fruits. Pkt., 10c; 0z., 15c; 2 oz., 25 ; $1 / 4$ lb., 40 c; lb., $\$ 1.50$.

Gherkin-Burr, or West India Round Prickly Cucumber; used for pickles only. Seeds require soaking before planting as they sprout slowly. Pkt., 5c: 0z., 15c; 1/4 lb., 40c: ih., $\$ 1.50$.

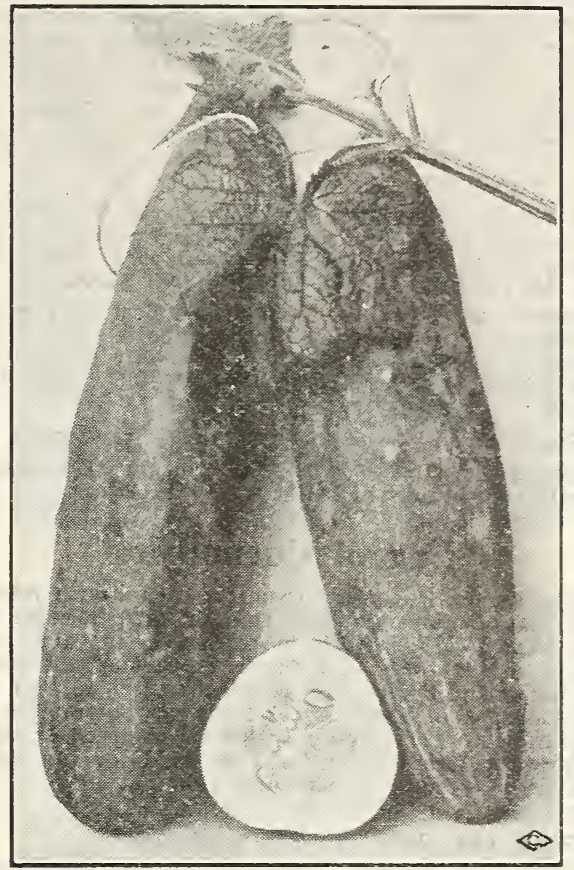

Davis Perfect

\section{Cucumbers-Slicing Varieties Arlington White Spine}

Vaughn's Improved-Medium size, very tender and early. Color a glossy gy een throughout their entire length, the shape very straight and symmetrical. As a home garden cucumber and for the Southern trucker, this is the jdeal variety. Pkt., 5c; 0z., 10c; 2 oz., 20c; 1/4 lb., 30c; lb., \$1.00.

Early White Spine Improved-Special strain of the popular White Spine Cusumber, most desirable for its extreme earliness. Fruits are smooth, reg. ular form, well colored, and of excellent flavor. Very popular in all sections of the country. Pkt., 5c; 0z., 10c; 2 oz., 20c; 1/4 lb., 30c; lb., \$1.00.

\section{Extra Long White Spine or Evergreen}

Selected Stock-The standard and most popular of the long White Spine varieties. One of the best for the greenhouse, the hotbed or for outdoor use. Early, vigorous and prolific; more blight-proof than the ordinary long sorts. "Fruits dark, shiny green. In shape straight and smooth. Flesh crisp, tender and of superb flavor; for geupral market and home use without a superior. Pkt., 5c; 0z., 10c; 2 0z., $20 \mathrm{c} ; 1 / 4 \mathrm{Ib}$., $30 \mathrm{c} ; \mathrm{lb} ., \$ 1.00$.

Davis' Perfect-The famous new Cucumber which produces Cucumbers out of doors that are equal to hothouse products, and so brings extra prices. Pkt.. 10c; 0z., 15c; 1/4 Ib., 50c; Ib., \$1.00.

See page 6 for special Cucumber offerings. 


\section{CUCUMBERS-Con't.}

\section{Ebbert's Famous}

The best Long Green Cucumber-of true White Spine type. Vines of vigorous growth, and produce enormous crops, fruits always straight and well formed, from 12 to 18 inches in length and extra solid. Color, very dark green (does not turn yellow). Flesh white, firm and crisp, and of delicious flavor. One of the very best market varieties. We strongly advise giving it a trial. Seed of our own growing. Pkt., 5c; 0z., 10c; $1 / 4$ lb., 30c; Ib., \$1.00.

Japanese Climblng-A useful variety for growing on a trellis or wire. Long, of dark green color, white flesh, crisp and of good flavor. Pkt., $5 \mathrm{c}$ : 0z., 10c; 2 oz., 20c; 1/4 lb., 30c; lb., $\$ 1.00$.

New Early Fortune-Earliest and best dark green Cucumber of the White Spine type. Color dark green, a model in shape and wonderfully productive. Pkt., 5c; 0z., 15c; 2 oz., 25c; 1/4 lb., 40c; lb., $\$ 1.25$.

Rocky Ford Klondike-See Specialties, page 6.

Serpent or Snake-A peculiar long Cucumber, usually much twisted. Pkt., $5 \mathrm{c}$; oz., $20 \mathrm{c}$.

\section{Lemon Cucumber}

The Lemon Cucumber is nearly round, with yellow and green markings and smooth skin similar to the Lemon. The flesh is tender, crisp, and possesses a sweetness and flavor surpassing all other Cucumbers. Fruits are from two and a half to three inches in diameter, and are very attractive in appearance. For pickling either when green or ripe, they are unexcelled. Should be used for the table just as the fruits are turning yellow.

Pickled as a gherkin it is delicious.

Prlce, pkt., 10c; oz., 25c, postpaid.

Write for Special Prices on Larger Quantities.

\section{Egg Plant}

Culture-Germinates slowly, and should be started under glass with moderately high temperature, about March 1 . When about an inch high

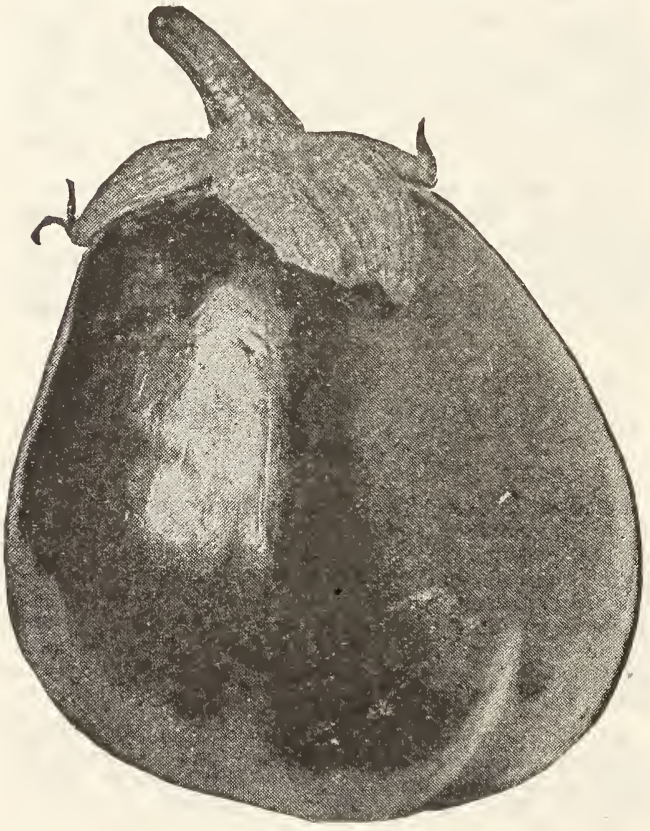

New York Improved Spineless transplant carefully to the garden or field, but not until all danger of frost is over, into warm, rich soil two or three feet apart each way, according to the richness of the ground. When about a foot high, draw the earth up to the stems. Care should be used in cutting the fruit, so as not to disturb the roots of the plant.

Now York Improved Spineless Large PurploThe leading variety known by market men everywhere; the plants are of low, stocky, branching habit and absolutely free from spines. A very early and continuous producer of handsome purple fruits of largest size and finest quality; the plants usually bear 8 to 10 immense fruits. The stock we offer is fine New Jersey grown. Pkt., 5c; oz., 60c; 2 oz., $\$ 1.00 ; 1 / 4$ lb., $\$ 1.75 ;$ lb., $\$ 6.00$.

Early Long Purplo-An early variety and also a very profitable one. The fruit is long and of a rich dark purple. Pkt., 10c; 0z. 60c; 2 oz., \$1.00; $1 / 4$ lb., \$1.75; ib., \$6.00.

Black Beauty -A distinct new Egg Plant of most remarkable merit. The fruit is quite as large as Improved N. Y. Purple, and from ten days to two weeks earlier than that variety. Very attractive in appearance, excellent flavor. Pkt., 5c; oz., 75c; 2 oz., $\$ 1.25$; $1 / 4$ lb., $\$ 2.00$ lb., $\$ 7.00$

Black Pekin-Fruit round, almost black. Flesh white, solid, fine grained and delicious. Quite early and of good marketable size. Pkt., 5c; 0z., 50c; 2 oz., 85c; $1 / 4$ Ib., $\$ 1.40$; Ib., $\$ 5.00$.

\section{Cress}

Culturo-There are two species of cress, as noted below. The first named should be sown in drills about 16 inches apart in rich ground, early in the spring. Several sowings should be made at intervals to secure a succession. Watercress should be sowed along the banks of running water where there is good soil, and after the seed is up it needs no further cultivation, since the plants spread over the water and make a mass of fine edible leaves.

Fine Curled (Pepper Grass)-Leaves finely cut or curled like parsley. The leaves are pungent, and are used to mix with lettuce. Pkt., 5c; oz.. 15c; 2 0z., 25c; $1 / 4$ lb., $40 c$; lb., $\$ 1.25$.

True Water-Forms a plant, the leaves of which are used for salad or for garnishing. Thrives only where the roots and stems are submerged in water. Pkt., 5c; oz., 30c; 1/4 lb., $\$ 1.00$.

\section{Gourds}

We are always mindful of the fact that unless our seeds give you satisfaction we will lose you as a customer. We want to retain you and will do $s 0$ if honorable methods and careful attention will accomplish it.

Japanese Nest Egg-These exactly resemble the egg of hens, making a capital nest egg; superior to glass, as they do not break. The plant is a rapid growing climber. Pkt., 5c; 0z., 10c; 1/4 lb., $35 \mathrm{c}$.

Sugar Trough-Very useiul for baskets, dishes, buckets, etc. Have hard, thick shells, lasting for years, and capable of holding from two to ten gallons each. Pkt., 5c; 0z., $10 \mathrm{c} ; 1 / 4 \mathrm{lb} ., 35 \mathrm{c}$.

Dipper-Named for its resemblance to a dipper. The capacity varies from a pint to a quart, with handles 6 to 12 inches long. They are convenient for dipping hot liquids, etc. Pkt., 5c; oz., 10c: $1 / 4$ lb. 35c.

Dishcloth or Lufin-A natural dishcloth and a most admirable one is furnished by the peculiar lining of this fruit, which is sponge-like, porous, elastic and durable. Pkt., 5c; 0z., 10c; 1/4 lb., 35c.

Mixed Gourds-All kinds, including Nest Egg, Dishcloth, Dipper, Japanese, etc. Pkt., 50: oz., 10c: $1 / 4$ ib., 350 . 


\section{Endive}

An excellent autumn and winter salad. Sow seed late in the spring or even as late as July, in shallow drills, 15 inches apart, and when plants are strong, thin out to about a foot apart. To blanch gather up the outer leaves over center of the plant, and tie them together at their tips.

Broad Leaved Batavian-Forms large heads of broad thick leaves which can be blanched as a salad or make excellent cooked greens, as well as being useful to flavor soup, stews, ets. Pkt., 5c; 0z. $20 \mathrm{c} ; 2$ oz., 35c; 1/4 ib., 55c; lb., \$1.75.

Green Curled-Leaves finely cut or lacinated, giving the plant a rich, mossy appearance which is greatly enhanced when the centers are nicely blanched. Pkt., 5c; 0z., 15c; 2 0z., 25c; 1/4 Ib., 40c; Ib., \$1.50.

White Curled-A light yellowish-green variety. Does not need blanching. Finely cut and curled leaves, almost white. Pkt., 5c; 0z., 20c; 2 oz. $35 \mathrm{c} ; 1 / 4$ lb., $55 \mathrm{c} ; \mathrm{lb} ., \$ 1.75$.

\section{Herbs}

Aromatic, Medicinal and Pot Herbs.

Anise-Used for garnishing, seasoning and for cordials. Pkt., 5c.

Balm-Used for making Balm wine and tea. Pkt., 5c.

Basil, Sweet-The leaves are used for flavoring soups, stews and highly seasoned dishes. Pkt., 5c.

Bene-The leaves immersed in a tumbler of water make a drink very beneficial in cases of dysentery. Pkt., 50.

Bohenkraut-(See Summer Savory).

Borago-Flowers excellent for bees. Leaves used in salads. The flower spikes can be used in cooling drinks. Pkt., 50.

Caraway-Seeds are used for flavoring bread, pastry, meats, etc. Pkt., 5c.

Catnip or Catmint-Grown for bee pasture. The leaves and young shoots are used for seasoning. Pkt., 10c.

Corriander-The seeds are used for flavoring. Pkt., $5 c$

Dill-Leaves are used in pickles and for flavoring soups and sauces. Pkt., 5c; 0z., 10c.

Fennel-Leaves boiled are used in fish sauce and are beautiful for garnishing. Seeds are used for flavoring. Pkt., $5 \mathrm{c}$.

Henbane-Growirg plants are supposed to absorb malaria. Pkt., 5c.

Hop Seed-PKt., 20c.

Horehound-Leaves are used for flavoring and also in the manufacture of cough remedies. Pkt., $5 c$.

Hyssop-Tops and flowers are used for Hyssop tea. Pkt., 5c.

Lavender-Leaves are sometimes used for seasoning, but the plant is chiefly grown for its flowers, which are used in the making of perfumes. Pkt., $5 c$.

Marjoram (Sweet)-Leaves and the end of the shoots are used for flavoring in summer they are also dried for winter use. Pkt., 5c.

5c.

Rosemary-Leaves are used for seasoning. Pkt.,

Ruo-For medical purposes, good for fowls for the roup. Pkt., 5c.

Saffron-Used for coloring certain dishes; also flavoring. Pkt., 5c.

Sage-Leaves and tops are used for seasoning and stuffing. Pkt., $5 \mathrm{c}$.

Summer Savory-Leaves and young shoots are used for flavoring, especially for boiled string beans. Pkt., 50.

Tarragon-Leaves of this plant are used to make Tarragon vinegar. Pkt, 10c.

Thymo-Used for seasoning; a tea is also made for nervous headache. Pkt., $5 \mathrm{c}$.

Wormwood-Beneficial for poultry; should be planted in poultry yards. Pkt., 5c.

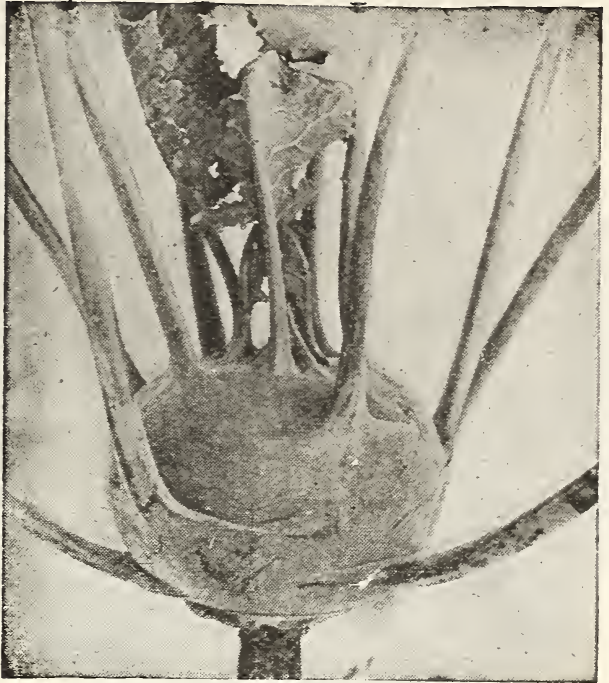

Early White Vienna

\section{Kale or Borecole}

A species of Cabbage, forming a mass of leaves, some varieties being very beautiful and curly. Leaves are cooked as greens. Seed should be planted in September, and plants will be ready to use in winter. Hardy and will stand frost and snow.

Culture-Same as Cabbage.

Dwarf German, or German Greens-(Dwarf Curled Scotch) - Leaves curly, bright green, very tender, and delicate in flavor. Pkt., $5 \mathrm{c} ; 0 z ., 30 \mathrm{c} ; 2$ oz., $55 c$; $1 / 4$ lb., 90c; lb., $\$ 3.00$.

Dwarf Siberian-0f dwarf growth, with large broad grayish-green leaves which are only slight curled at the edges. Extremely hardy. Pkt., 5c; $0 z ., 20 c ; 2$ 0z., 35c; $1 / 4$ lb., 60c; lb., $\$ 2.00$.

Tall Green Curled Scotcti-Makes a beautiful plant about $2 \frac{1 / 2}{2}$ feet high. Pkt., $5 \mathrm{c}$; 0z., 30c; 2 0z.. 50c; $1 / 4$ Ib., 90c; Ib., $\$ 2.75$.

\section{Kohl Rabi}

Sown for general crop in the spring, like turnip, in drills; or may be transplanted like cabbage. For winter use, sow middle of June. Gather when small and tender, as later it becomes tough and stringy. The stem, just above the surface of the ground, swells into a bulb something like a turnip.

Earliest White Vienna-Greenish- white outside, with clear-white flesh within. Smooth, short leaf; good for forcing; fine quality. Pkt., $5 \mathrm{c}$; 0z., 20c; $1 / 4$ lb., 60c; lb., $\$ 2.00$.

Earliest Purple Vienna-Same in every respect 28 the Earliest White Vienna, except in the outside color. Pkt., 5c; 0z., 20c; 1/4 Ib., 600; Ib., \$2.00.

\section{Leek}

Sow in drills one foot apart and half-inch deep, in light, rich soil, liberally manured; thin the plant. to 10 inches.

Large American Flag-Has become very popular with market gardeners on account of its being larger than the London Flag. Pkt., $5 c ; 02 ., 15 c ; 1 / 4$ lb., 40c.

Large Musselburg-Enormous size, leaves large and broad, mild, pleasant flavor. Pkt., 5c; 0z., $15 c$; $1 / a$ lb., $40 c$. 


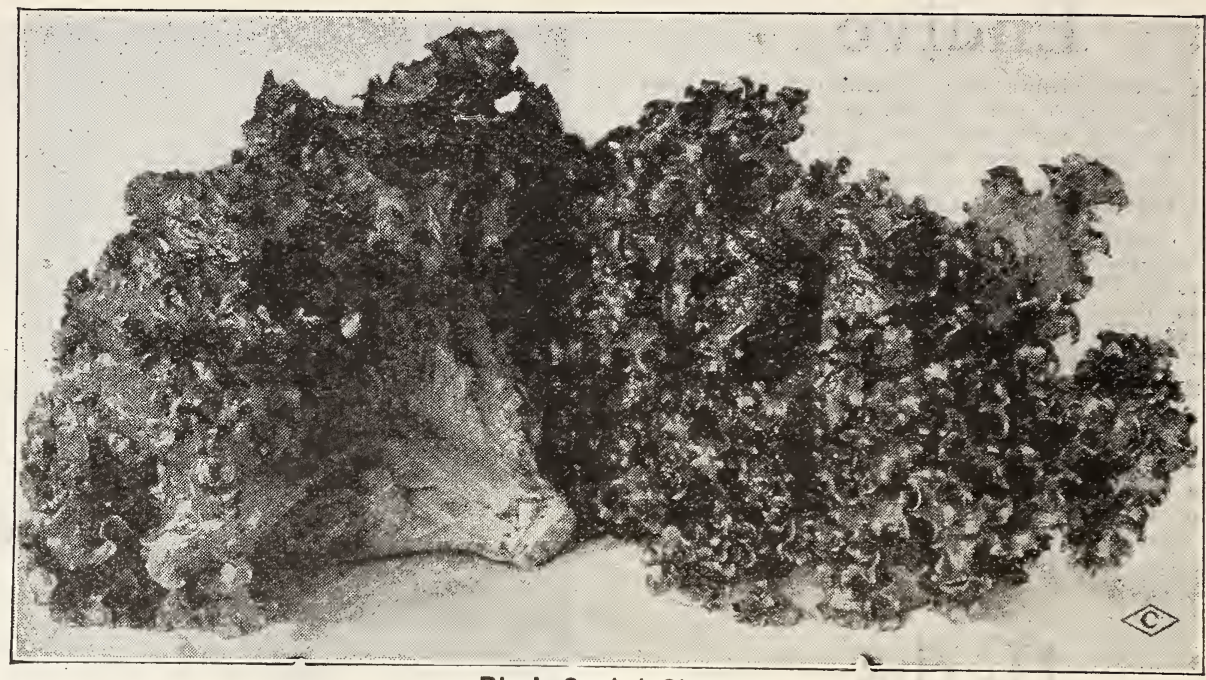

Black Seeded Simpson

\section{Lettuce}

in Demand-the Whole Year Round. A MoneyMaking Crop for Market Gardeners.

Culture-There are two disfinct classes of Lettuce. One forms heads like cabbage; the other merely produces loose leaves.

Probably no vegetable is more universally used than lettuce, and to be full appreciated it must be brought to the table fresh and unwilted. As it requires but little room and is of the easiest culture, there are but few families who cannot have it direct from the bed. The quality of lettuce depends on the rapid and vigorous growth. Sow in hotbed in March and in open ground as early as can be worked, sow thinly in drills one foot apart. For a succession sow every three weeks during the season. The soil should be rich and mellow. Thin out plants as they grow so that the plants left to head will stand 10 to 12 inches apart in the rows.

Our Lettuce seed is grown for us under contract by one of California's largest growers.

\section{Curled or Loose Leaf Varieties}

Black-Seeded Simpson-The most popular sort of all the non-heading varieties. One of the best for use under glass, as well as for early outdoor planting. The leaves form large, loose heads; outer leaves a light, yellowish green, with inner leaves blanched almost white. Resists the heat and remains long in a good edible condition. Pkt., 5c; 0z., 10c; $1 / 4$ Ib., 35c; Ib., \$1.25.

Early Curled Simpson (Silesia) - A leading early sort; does not bead, but forms a compact mass of curly leaves of yellowish green. Matures early; generally grown in cold frames and as an early crop. Very tender and most crisp. Pkt., 5c; 0z., $10 c$; $1 / 4$ Ib., 35c; Ib., \$1.25.

Grand Rapids Forcing-The well-known forcing variety for the Middle West. It grows very rapidly, forming large, loose, curled bunches. The color is a yellowish greeen. The leaves are crisp, tender and fine flavored. As an outdoor lettuce for cutting when a few inches high, we know of no better sort than the Grand Rapids. Pkt., 5c; 0z., 10c; 1/4 Ib. 35c Ib., \$1.00.

Early Prize Head-This popular variety produces large, loose heads of finely crimpled and fringed leaves, the outer portions of which are shaded with brown. Exceedingly crisp, sweet and tender. One of the best for the home garden. Pkt., 5c; 0z., $10 \mathrm{c}$; $1 / 4$ lb., $35 \mathrm{c}$; lb., $\$ 1.00$.

Paris White Cos.- The Cos Lettuce differs entirely in shape from the other varieties, the head being elongated and of conical form, 8 or 9 inches in height and 5 or 6 inches in diameter. The outer coloring of this variety is yellowish green. To be had in perfection it requires to be tied up to insure blanching. Pkt., 5c; 02., 20c; 1/4 Ib., 35c; Ib., $\$ 1.00$.

\section{Cabbage or Heading Varieties}

Big Boston-The most popular variety for the Southern gardener who ships North. Also very val uable as first early in the North. Plants are large, vigorous; leaves are bright light green, very tender. Our strain is unsurpassed. 'This variety is identical in color, shape and general appearance with the famous Boston Market Lettuce, but is double the size. Pkt., 5c; 0z., 10c; I/4 Ib., 35c; Ib., \$1.25.

Boston Market (White Seeded Tennls Ball) The well known and popular hothouse vareity of New England. Light green Cabbage variety, slightly tinged with brown on the head. Forms a compact buttery head. Pkt., 5c; 0z., 10c; 1/4 Ib., 35c; Ib., \$1.25.

Black Seeded Tennls Ball-An old, well-known variety. Very desirable for hot-bed culture in winter and for withstanding leat in summer. $A$ light-green Cabbage sort, forming hard heads. Pkt. 5c; 0Z., 10c; 1/4 Ib., 35c; Ib., \$1.25.

California Cream Butter, or Royal Summer Cab. bago-Also a popular variety with Southern shippers. A grand good Butter Lettuce. Heads very large, round and solid; outside green; within the leaves are a rich creamy yellow color; most delicious and buttery in taste. Pkt., 5c; oz., 10c; 1/4 Ib., 35c; Ib., \$1.25.

Denver Market-An early variety of head Lettuce, either for forcing or open ground; forms large, solid heads; light green color and is slow to go to seed; leaves are beautifully marked and blistered; crisp, tender and of excellent flavor. Pkt., 5c;0z., 15c; 1/4 lb., 35c; Ib., \$1.10.

Improved Hanson-This standard variety is the most planted of all head Lettuce. It is a well known and well tried sort, and its merits have been proven on all markets.' Deliciously sweet, crisp and tender and almost absolutely free from any rank or bitter taste. Resists the summer heat extremely well. It cannot be too highly praised. Pkt., $5 c$; 0z., 10c; $1 / 4$ Ib., 35c; lb., \$1.25.

lcoberg-A very hard heading and beautiful sort, excellent for summer use. Inner leaves finely blanched, crisp and brittle; of sweet and refreshing flavor. Pkt., 10c; 0z., 20c; 1/4 lb., 60c; lb., \$2.00

May King-A very early new variety, forming fine hard heads within a few weeks after planting. It is medium sized, light green, with buttery but crisp heads. There is just \& faint tint of brown on the head. Pkt., 5c; oz., 10c; $1 / 4 \mathrm{Ib} ., 35 \mathrm{c}$; Ib., $\$ 1.50$. 


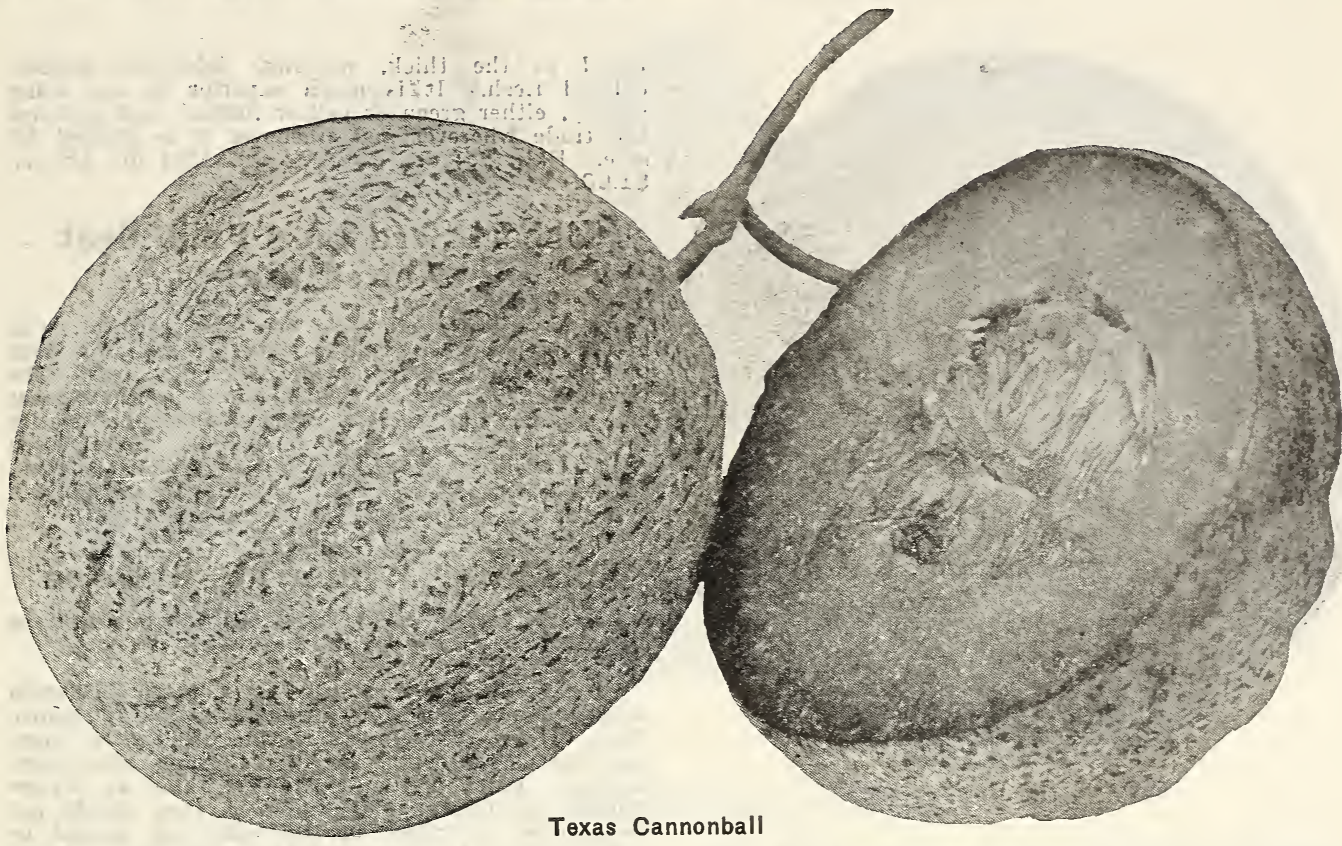

\section{Cantaloupe or Muskmelon}

\section{Extra Selected, Saved Only From Melons Grown Specially for Seed.}

We strive to supply Melon sceds of highest quality. We have them grown where they reach the highest point of perfection by the most reliable growers, and are in a position to offer strains far superior to the commercial grades, commonly sold by seedsmen.

Culturo-Musk Melons and Cantaloupes thrive best in a rich, warm, well-drained sandy loam soil thoroughly prepared. Plant in hills about 6 feet apart each way 10 to 12 seeds in a hill, about one inch in depth. When the plants are well up, after all danger from frost and insects is past, thin to one to two plants in a hill. Hoe often and give frequent shallow cultivation. If molested by the cucumber beetle, dust lightly with wood ashes or air. slacked lime.

\section{Green Fleshed Varieties}

(For Rocky Ford Varieties, see special pages).

Baltimore or Acme-A very productive melon; the favorite market variety. Oblong shape, twice as large as Rocky Ford, well netted and ribbed; flesh quite thick, light green in color, sweet and of fine quality. Pkt., 5c; 0z., 10c; 1/4 Ib., 30c; Ib., \$1.00.

Champion Market-Splendid variety of Netted Gem type, producing fruits nearly three times as large as the "Rocky Ford." T ery regular in form, nearly round, averaging eight inches in diameter, heavy, well netted ribs, thick, light-green flesh, very thin rind, true Netted Fem flavor. Pkt., 5c; $0 z ., 10 c$; $1 / 4$ Ib., 35c; lb., 15 oz., \$1.00.

Extra Early Hackensack-'This is a selection of the popular Hackensack, ripening fully. ten days earlier. Melons of good size, heavily ribbed and netted; thick, light-green flesis of fine flavor. Pkt., 5c; 0z., 10c; 1/4 lb., 30c; lb., 15 0z., \$1.00.

Large Hackensack, or Turk's Cap-Popular with market gardeners near large cities. It is very hardy and productive, the fruits are of good size, round, beavily ribbed and netted. The meat is green, thick, firm and of excellent flavor. Pkt., 50; 0z., 100; $1 / 4$ Ib., 30c; Ib., \$1.10.
Texas Cannon-Ball-This favorite melon originated in Texas; it is perfectly round, heavily netted, green flesh of excedingly fine flavor, very small seed cavity. Its value for both licme use and shipping has never been fully appreciated. Do not fair to give this variety a trial. Pkt., 5c; 0z., 10c; 1/4 lb., $30 \mathrm{c} ; \mathrm{Ib} ., \$ 1.00$.

Extra-Early Jenny Lind-One of the earliest melons in cultivation. Smull, round fruits, flattened on both ends, deeply lobed and finely netted. The meat is green and luscious. Introduced many years ago and has always been a great favorite for family use. Is one of the most prolific Cantalounes grown. Pkt., 5c; 0z., 10c; 1/4 lb., 30c; Ib., $\$ 1.00$.

Montreal Market-Fruit of the largest size, often attaining a weight of fifteen to twenty pounds. Shape nearly round, flattened at the ends, deeply ribbed; flesh remarkably thick, green, melting and of the finest flavor. Pkt., 5c; oz., 15c; 2 oz., 25c I/4 lb., 40c; 15 oz., \$1.00.

Netted Nutmeg-A very early melon of small size, varying in shape from almost oval to a flattened globe. Skin green until over ripe, when it becomes yellow; flesh light green, very thick and sweet. Pkt., 5c; 0z., 10c; 1/4 lb., 25c; Ib., 80c.

\section{Salmon Fleshed Varieties}

Burrell Gem (Salmon Fleshed Rocky Ford)Locally known as Burrell Gem, Osage Gem and Ordway Pink Meat. For description, see specialties, page 3.

Burpee's Fordhook-It is about the same size as Improved Jenny Lind, very thick flesh, of the orange-yellow, very small seed cavity, comparative ly few seeds, flesh very solid and of very high flavor, flesh staying solid and firm after melon has become quite yellow, making it an excellent long distance shipper. Pkt., 5c; 0z., 15c; 1/4 Ib., 40c; Ib., \$1.50.

Emerald Gem-Undoubtedly the finest in flavor and the earliest to ripen, and while too soft to stand shipping any great distance, is unequalled for home use or nearby markets. Vines of strong and vigorous growth; very prolific. Is rather small and flattened st both ends. Enerald green, smooth and free trom netting, heavily ribbed, with narrow bands of lighter green between ribs. Flesb vert thick, and rich salmon color. Pkt., 50; 02., 15c; $1 / 4$ lb., 40c; Ib., 15c; 0z., \$1.00. 


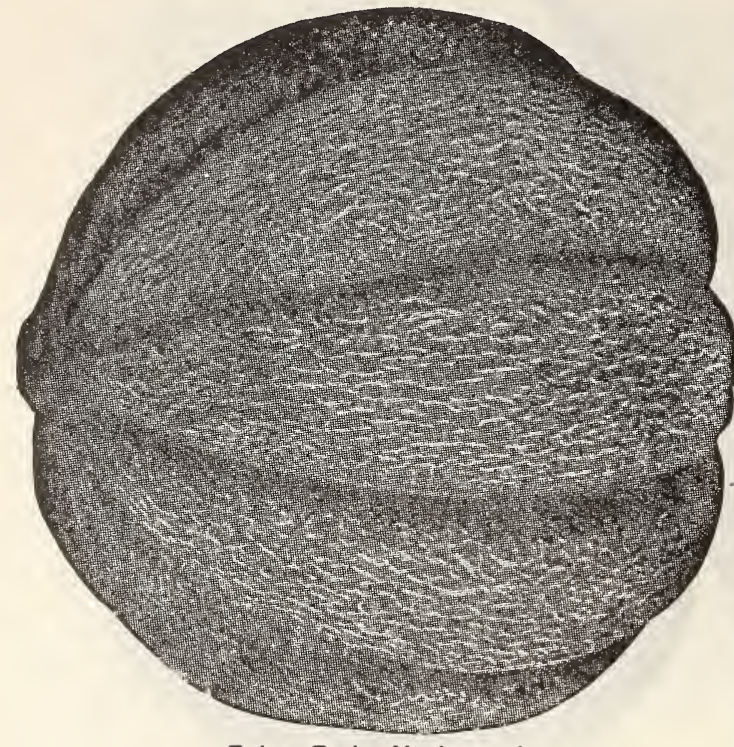

Extra Early Hackensack

Hoodoo-(See specialties, page 4)-A new orange fleshed variety, ideal as a shipping melon and of the very finest quality.

Banana-A very remarkable variety, growing from 18 to 30 inches long, the skin is smooth and a light yellow. Flesh a salmon red. Sells well on account of its odd and peculiar shape. Very desirable for tamily use. Pkt., 5c; 0z., 15c; 1/4 lb., 40c; lb., 15 oz., \$1.00.

Osage, or Miller's Cream-A favorite salmonfleshed variety. Large, oval, slightly ribbed and netted; skin very dark green, very thick and sweet flavored, most delicious to the rind. A favorite for market purposes and the home garden. Pkt., 5c; 0z., 10c; I/4 Ib., 30c; Ib., \$1.00.

Paul Rose or Petosky-A yellow fleshed sort, uitable size for a basket melon and of the finest quality. Fruit oval, about five inches in diameter and in general appearance much like the Netted Gem, but a little larger. Flesh orange-colored and high-flavored, very thick, firm and sweet. Pkt., Sc; 02., 10c; 1/4 Ib., 30c; Ib., \$1.00.

Peach or Garden Lemon-For sweet pickles, preserving, etc. it is one of the finest articles to be obtained. Pkt., 5c; 0z., IOc; 1/4 lb., 40c; Ib., $\$ 1.25$.

Tip Top-This very productive melon is of large aize, nearly round, slightly ribbed and fairly well covered with shallow netting. The flesh is deep yellow in color and of excellent quality. An excellent market variety, and sells on sight. Pkt., $5 \mathrm{c}$; 0z., 10c; $1 / 4$ lb., 25o; Ib., 850.

Yollow Meated Japan-The vines are hardy, very prolific and produce very large fruits, nearly as early as the smaller varieties. The melons are nearly round, not deeply ribbed and covered with patches of netting. The skin is yellowish white when ripe. The crowning feature of this melon is found in the thick, melting, delicious, salmoncolored flesh. It is much superior to any other variety, either green or yellow fleshed, and captures the trade wherever and wherever it is offered for sale. Pkt., 5c; 0z., 10c; 1/4 Ib., 35c; Ib., 15 oz., $\$ 1.00$.

\section{Ebbert Seed Co.'s Pink Meat Netted Rock}

An extra early standard size rust-resistant, well netted melon with small caviety. Flesh of a dark pink or salmon color. Is of delicious flavor. The very essential point to this melon is its thick meat and small cavity, thereby insuring the main quality to be desired in a shipping melon. Select soed (saved from the earliest and best melons). Pkt., 5c; 0z., 15c; l/4 lb., 40c; per lb., 15 0z., \$1.00.

Write for prices in larger quantities.

\section{Casaba or Winter Musk Melon}

(A late variety of Musk Melons which should be classed in a family. by themselves).

The Casaba was introduced ia southern California several years ago, and although favorably known there, is but little known in the country at large, and has but recently become a commercial com. modity. Plant and cultivate the same as Watermelons and Cantaloupes; however, they should not be allowed to ripen on the vine, but should be picked about the time of the appearance of the first frost and carefully stored away or packed in straw in a barn, cellar or some cool place until they become slightly soft, when they are ready to eat. This is usually from four to eight weeks after they have been picked, but for shipping should be packed in crates with straw and shipped as soon 28 picked with instructions: "Not to be eaten until they become slightly soft."

We offer three of the best varieties of this late melon.

Improved Hybrld-This is the finest flavored and best of the Casaba family. The favorite home garden and local market variety. On account of its delicate makeup, it is not a good shipper. Color dark green, heavily ribbed and wrinkled. The flesh is from two to three inches in thickness, color creamy white and is melting and delicious. Every carden should contain a few hills of this excellent winter melon. Pkt., 10c; oz, 20c; $1 / 4$ lb., 60c; lb., 15 0z., \$2.00.

Golden Beauty-Similar in all respects to the winter pineapple, except its golden color, which gives it a refdy sale. One of the finest flarored Casabas, an excellent keeper and a favorite shipper. Try it. Pkt., 10c; 02., 20c; $1 / 4$ lb., 60c; lb., 15 $0 z$., \$2.00.

Winter Pineapplo-This is the green melon used extensively for shipping East for the holiday and winter trade. Melons do not mature on the vines and the flavor is greatly improved by being stored in a cool place. Pkt., $10 \mathrm{c} ; 02 ., 20 \mathrm{c} ; 1 / 4 \mathrm{lb} ., 60 \mathrm{c}$; Ib., \$1.50.

At prices quoted in this Catalog, we prepay the Postage or Express charges, unless otherwise noted. Write for special prices on large quantities.

NOTTCF: Owing to the great shortage in many varieties of vegetable seeds, the prices quoted in this catalog will hold only so long as our present stock lasts. (This applies only to the varieties on which there is a great shortage.) Should our present stock on the short varieties be sold out on receipt of your order, the prevailing market price will then apply, or we reserve the right to return the money on items that we can not supply at catalog prices. 


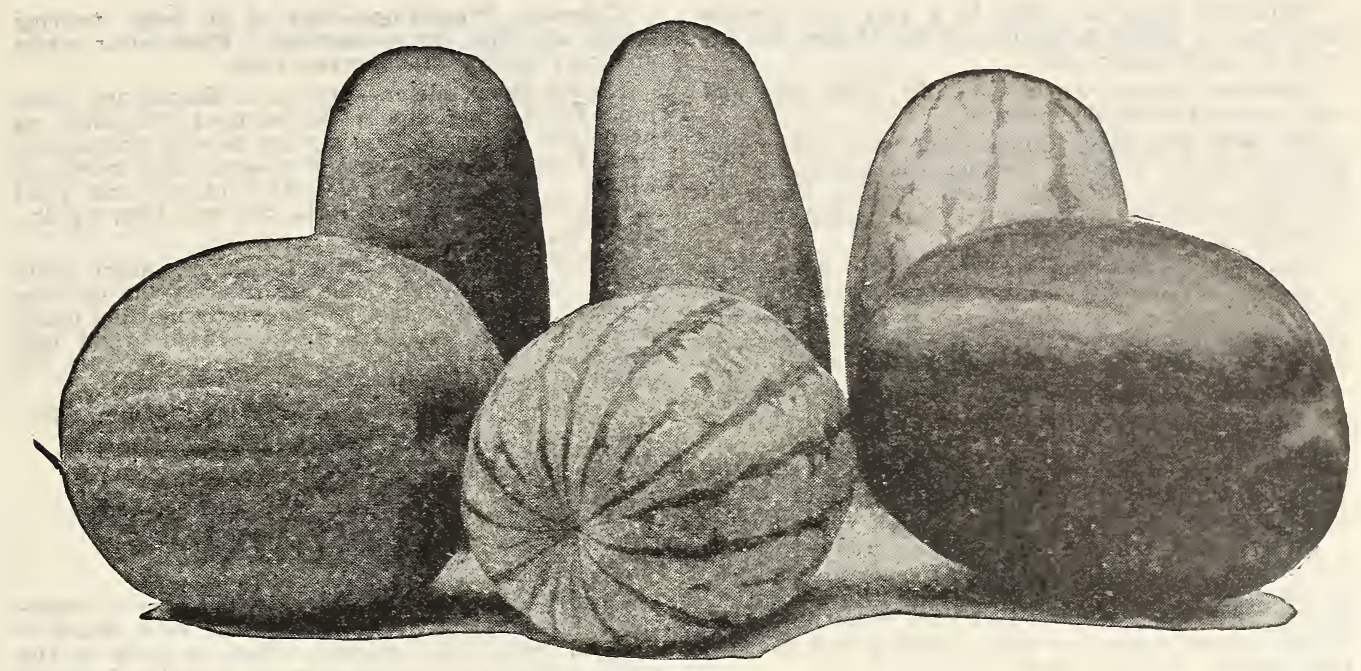

\section{Watermelons}

The Best New and Standard Varieties.

Choice Watermelon seed is one of our specialties. We handle nothing but the best. All our stock is strictly fresh. The varieties that we do not produce are grown for us under contract by one of the best known growers in Florida

Prices on all Watermelon seed (except where otherwise noted),Pkt., 5c; 0z.; 10c; 1/4 Ib., 30c; Ib., $\$ 1.00$.

Alabama Sweet- This is undoubtedly the finest flavored shipping melon ever introduced and the favorite with the Texas and cther Southern shippers. It is a large, oblong melon, with rather dark green rind, marked with a darker green stripe. The skin is thin and very tough and is not injured in handling nor in shipping. The nesh is bright red, fine grained, firm and entirely stringless. Average weight over 20 pounds. We offer two grades of this seed of our own growing. Pkt., 5c; 0z., 10c; 2 oz., 15c; 1/4 lb., 25c; Ib., 75c.

Bradford-A favorite above all others in sections where it has been grown; very productive. The melons grow to a large size, elongated in shape; rind dark green, with darker stripe; flesh red and remarkably tender and sweet.

Black Diamond-A cross letween Kolb's Gem and Hoosier King; one of the most prolific watermelons ever planted; color rich, dark green, almost black; symmetrical in shape, 18 an excellent shipper and possesses all of the good eating qualities. Melons weighing from 40 to 6.0 pounds are not uncommon among this variety.

Black Spanish-Very sweet and delicious variety. Fruit round, of large size, skin blackish green and scarlet flesh.

New Chilian Watermelon-This fine melon has been very popular in southern Calfiornia for several years and deserves to be better known through the entire country. It is nearly round, skin dark green; slightly mottled and striped with a darker green; rind very thin, but hard. Flesh is bright red, heart large and stringless, flavor unsurpassed. It is a good shipper. We offer both Colorado grown seed and California grown. White seed: Pkt., 5c; 0z., 10c; 1/4 lb., 30c; lb., \$1.00.

Red Seeded Chilian, 10 days earlier than white, same price.

Black Seeded-Earliest variety. Pkt., 5c; 0z., $10 \mathrm{c} ; 1 / 4 \mathrm{lb} ., 30 \mathrm{c}$; Ib., $\$ 1.00$.

Cole's Early-An extra early melon, ripening sev. eral days in advance of any other truits, are oval and striped with light and dark green. We do not recommend this melon for shipping; it is too small to be marketable, but for home use or for raising in locations where the season is short, it is very satisfactory.

Cuban Queen-This is a large variety, often weighing 80 pounds and upwards; striped light and dark green; an enormous cropper.

Improved Dixio-Fruit beautifully striped; sur. passed by few for shipping or table; long keeper; flesh very red, sweet and juicy; quality excellent.

Duke Jones (Jones' Jumbo)-Color of the skin is a solid dark green; flesh of very bright red par. ticularly sweet, juicy and melting. It grows to a large size.

Fordhook Early-The largest and best early melon of good size. Next to Cole's Early in time of ripen. ing, but much larger. Fruit round; outer color medium green; flesh bright $r \in d$ of fine quality. $\Delta$ good shipper.

Florlda Favorlto - A splendid oblong melon; ten days earlier than Kolb's Gem. Skin dark-green, slightly mottled with still deeper shade; flesh darkred and of finest flavor and quality. We have a splendid stock.

Gypsy, or Georgia Rattlesnako-Standard Southern variety, which possesses remarkable shipping qualities, long, smooth, distinetly striped with light mottled and wavy, dark green, regular stripes. Flesh bright scarlet and very sugary.

Iceberg (Blue Gem)-Uniformly large, of thick oval form; dark green, with faint stripings. The rind is exceptionally strong, making it an excellent shipper. The flesh is entirely free from stringiness and of sweet, sugary flavor.

Halbert Honey - This new melon equaling in flavor and as handsome in color as Kleckley's Sweets but more regular in form. They average 18 to 20 inches in length. The flesh is a beautiful crimson, of luscious quality, melting and sweet as honey, of dark and light green. Rind exceedingly hard and firm, making it a good sort for shipping. Flesh bright red, solid, a little coarse, but sweet and tender.

Kentucky Wonder-This is a superior melon in every way. Oblong in shape, skin very dark green, marbled with a lighter green; the flesh is a beautiful deep scarlet, crisp, tender, rich and very sweet; an excellent keeper and fine for market as well as for home use. The average weight is 50 pounds. 
Mammoth Ironclad-This is a very well known large melon, which is similar to the Gypsy, but attains a much larger size.

Mountain Sweet-An old standby, large size and well adapted to garden culture.

Mclver's Wonderful Sugar-The sweetest melon grown; attains a great weight; has handsome appearance; never cracks or loses its fine flavor in the wettest season. The color is light green, shaded with darker stripes.

Phinney's Early-Few, if any, of the early sorts of recent introduction surpass this old favorite. It is first to ripen, of good size and productive; shape oblong; rind a distinct mottied color; the flesh is a deep red; first class early market melon.

Pride of Georgia-A dark green, oval variety; a very fine, large, second-early sort; a good shipper and keeper.

Seminole-An exceedingly productive variety of large size. Fruit oblong in shape; flesh solid, ripening clear up to the rind.

Sweet Heart-One of the very best early varieties for the home garden, of the largest size, nearly globular in shape; skin a bright, beautiful, mottled green; rind thin; flesh bright red, firm and solid to the center, heavy but crisp, melting and exceedingly sweet. A good keeper.

Ice Cream, or Peerless-The old but extremely popular home market melon. Medium in size, almost round; the skin a pale grean; flesh bright scarlet, fine-grained, solid to the center, sweet, crisp and melting.

Kleckley Sweets-This is one of the finest flavored Melons grown-(See specialties, page 5).

Improved Kolb's Gem-Excellent shipper and largely grown for Northern markets. Fruit of the largest size, round or slightly oval, marked with irregular inottled stripes.

\section{Sugar Boy Watermelon}

The introducer describes it as follows:

The best of the entire lot. It is the most delicious thing in the shape of a watermelon that we have ever known. The fruits are oblong, a little inclined to be barrel shape; rind is very dark, almost a black green and is tough, thick and smooth. The flesh is bright red and ripens up well to the rind. It is absolutely free from any stringiness; sweet as honey and of the most melting and delicious flavor. Pkt., $5 \mathrm{c}$; 0z., 10c; $1 / 4$ lb., 30c; Ib., $\$ 1.00$.

Triumph-Fancy selected Southern grown seedGrows to larger size than any other melon in cultivation. It is a cross between Duke Jones and Kolb's Gem. It has the handsome appearance of the former and the shipping qualities of Gem; very early, prolific, deliciously sweet.

Tom Watson-A novelty in Watermelons and of sterling merit. (See specialties, page 5 ).

Round Light lcing, or lce Rind-1 hls is equally as fine flavored at the Dark Icing from which it differs only in having clear light-colored skin.

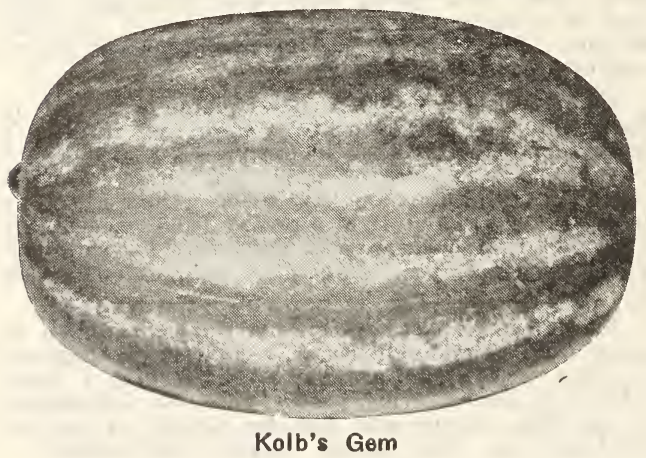

Colorado Preservlng-This is a large fruiting strain of citron for preserving. Flesh clear white and very solid. Olive green seed.

Kansas Stock Melon-Grown in Kansas and Colorado for feeding stock; to be used the same as beets and turnips. This variety is very productive: flesh firm and solid, with few seeds, and keeps all winter. They grow on any kind of soil and yield largely in dry seasons. Pkt., 5c; 0z., 10c; $1 / 4 \mathrm{lb}$., 30c; Ib., 80c.

Harris' Earliest-A splendid large, extra early melon of exceptionally fine quality. Fruit uniform in shape, slightly oval with irregularly mottled broad stripes of light and dark green. Flesh bright red, sweet and tender. One of the most desirable for planting in the North.

King and Queen-The ideal Winter Watermelon. SEE SPECIALTIES-PAGE 7 for description.

\section{Mustard}

Culture-Mustard is not only used as a condiment, but the green leaves are used as a salad or cut and boiled like spinach. Sow as early in the spring as the ground will permit, in drills about 18 inches apart, covering one-half inch deep. For succession, sow every few weeks till autumn. The plants are used early in the spring as a salad and for greens.

Chinese Curled-Highly esteemed for salads in the South. The leaves are twice the size of the ordinary white mustard. Flavor sweet and pungent. Pkt., 10c; 0z., 15c; 2 0z., 20c; 1/4 lb., 25c; Ib., 80c.

Ostrich Plume-The leaves are long, ruffled and frilled. The edges are curled like double curled parsley, making the leaves equally as desirable for garnishing. It stands well even during the hot summer months, while the leaves can be cut quite as early as those of other sorts and are unsurpassed for "greens," being available before any other vegetable. Pkt., 5c; 0z., 15c; 1/4 Ib., 25c; Ib., 80c.

Southern Giant Curled-Very highly esteemed in the South, where the seed is sown in the fall and plants used very early in the spring as a salad. Seeds brown in color. Plants two feet high. Forms enormous bunches. Pkt., 10c; 0z., 15c; 2 0z., 20c; 1/4 Ib., 25c; Ib., 75c.

White English-Leaves are light green, mild and tender when young; seed light yellow in color. Pkt., $5 c$; 0z., 10c; 1/4 lb., 20c; lb., 60c.

Brown or Black Mustard-More pungent in flavor than the White. Seed black. Pkt., 5c; 0z., 10c; $1 / 4$ Ib., 20c; Ib., 60c.

\section{Okra or Gumbo}

Culture-The young, tender seed-pods of this plant are used for flavoring soups, stews, etc. They are regarded as a household necessity in the South, but are neither so well known nor so extensively grown in the North. Seeds should be sown when the weather has firmly become settled, in drills, three feet apart. Thin out the plants that they stand one to two feet apart in the row. Gather the pods while they are young as they become tough and woody as they get larger.

Dwarf Green-Bears pods ready for use ten days to two weeks earlier than the tall sorts. The plants are of dwarf, stocky growth and very prolific. Pkt., 5c; 0z., 10c; 1/4 lb., 25c; lb., 60c.

Perkins' Mammoth Long Pod-The plant is dwarf growing, even in size and prolluctive, maturing pods earlier than most sorts. The pods are long, slender, deep green and remain tender much longer than most sorts. Pkt., 5c; 0z., 10c; I/4 Ib., 25c; lb. 60c.

White Velvet-The pods are perfectly round, smooth and of an attractive white velvet appear ance; of superior flavor and tenderness. Pkt., 50; 0z., 10c; 1/4 Ib., 25c; Ib., 60c. 


\section{Ebbert Seed Co.'s Onion Seeds}

\section{HIGH GRADE ONION SEEDS OUR SPECIALTY}

Our seeds are grown especlally for us by the best onion seed growers In the country.

Culture. - Thrives best in a rather deep, rich loamy soil and, unlike most vegetables, succeeds well when cultivated on the same ground for successive years. The ground should be deeply trenched and manured the previous autumn, and laid up in ridges during the winter to soften. As early in the spring as the ground is in working order commence operations by leveling the ground with a rake and tread it firmly; sow thinly in rows, four pounds to the acre, and a quarter of an inch deep and one foot apart; cover with fine soil and press down with the back of a spade or light roller. When the young plants are strong enough, thin gradually, so that they stand three to four inches apart. Keep the surface of the ground open and free from weeds by frequent hoeing, taking care not to stir the soil too deeply or collect it about the growing bulb. As soon as the tops die and fall, the bulbs should be gathered into windrows. If the weather is fine they will need no attention while curing, but it it is not they will need to be stirred by simply moving them slightly along the row. Cut off the tops when perfectly dry, about half an inch from the bulb and then after a few days of bright weather the onions will be fit to store for winter.

\section{Yellow Varieties}

Prizetaker-This is the large, beautiful Spanish variety so often seen in the fruit stores and markets of all large cities. Grows to an immense size and for fall marketing is unexcelled. Although of such great size, it 18 very hardy and a fair winter keeper, as it ripens-up bard and firm; very fine grained, and of mild, delicate flavor. The outside skin is rich yellow whlie the flesh is white. Our stock is True American-grown seed, being far superior to the imported seed which is offered at a considerably iess price. Can furnish both Colorado and California grown seed. Pkt., 5c; oz., 15c; 2 oz., 25c; 1/4 lb., 40c; lb., \$1.50.

Yellow Globe Danvers-A favorite variety in the East where it is grown almost to the exclusion of all other sorts; bright yellow in color; a perfect keeper and a heavy yielder. Pkt., 10c; 0z., 15c; 2 oz., 25c; 1/4 lb., 40c; Ib., \$1.50.

Flat Yellow Danvers-Like the Globe Yellow Danvers, but rather more flattened. One of the best keeping Onions grown; flesh white, fine grained, firm and mild; perfect in shape and a large cropper. Pkt., 5c; oz., 15c; 2 oz., 25c; $1 / 4$ lb., $40 \mathrm{c}$; Ib., $\$ 1.40$.

Southport Yellow Globe-1 large perfectly shaped Globe Onion and an excellent Onion for keeping throughout the winter. A very heavy cropper, handsome in appearance and good dark yellow color. Pkt., 10c; 0z., 15c; 2 oz., 25c; 1/4 lb., 40c; lb., $\$ 1.50$.

\section{Red Varieties}

Extra Early Red Flat-The first red Onion to ripen. A medium-sized, flat variety; an abundant producer and very uniform in shape and size; comes into use nearly two weeks earlier than the Large Red Wethersfield. Very desirable for early market use. Pkt., 10c; 0z., 15c; 2 oz., 25c; 1/4 Ib., 40c; lb., \$1.50.

Large Red Wethersfield-The most widely cultivated red variety, the standard winter Onion in many Northern states. The kulbs are well flattened, thick through and grow to a good size. The skin is of a rich, glossy deep red color, while the flesh is white, tinged with red. A most excellent keeper. Pkt., 10c; 0z., 15c; 2 oz., 25c; I/4 Ib., 40c; Ib., $\$ 1.50$.

Southport Red Globe-This handsome and most richly colored of all red sorts is becoming more popular every season. It is of a rich, glossy, dark red color, and of a very showy appeurance in the market. Remarkably uniform in size and good keeper. Pkt., $10 \mathrm{c}$; 0z., 15c; 2 oz., 25c; 1/4 lb., 40c; Ib., \$1.50.

Australian Brown-Since its introduction a few years ago it has become one of the most popular and most sought after Onions in many markets. Its remarkable keeping qualities and handsome appearance have brought it rapidly to the front. This Onion has a clear amber-brown skin that attracts buyers. It matures early, ripens uniformly, and will keep in good condition longer than any other Onion. Pkt., 5c: 0z., 20c: 1/4 Ib., 70c; lb., \$2.00.

\section{White Varieties}

White Portugal, or Silver Skin-A beautiful standard white Onion. The flesh is mild while the skin is a beautiful clear silvery white. A favorite when young as a bunching or salad Onion, but is also a good keeper and fine for fall use. An excellent variety when one or two varieties are to be planted. Pkt., 10c; 0z., 25c; 2 oz., 40c; $1 / 4$ lb., 75c; ib., \$2.25.

\section{Bermuda Onions}

Culture-The seed is sown in beds as early in the fall as the same can be obtained, and transplanted to the field when about four inches in height and cultivated the same as other onions. The genuine seed is all imported from Teneriffe, Canary Islands, off the west coast of Africa, and gives far better results than the seed grown in California.

White Bermuda-The favorite market variety. While known as "White Bermuda" it is really light straw color, or pale veilow. Pkt., 5c; 0z., 35c; 2 oz., 60c; 1/4 lb., $\$ 1.00$; lb., $\$ 3.50$.

Red Bermuda-Identical in size, shape and mild ness with the "White Bermuda;" color pale waxy red. A favorite in some sections. Pkt., 5c; 0z., $30 c ; 2$ oz., 55c; 1/4 lb., 90c; lb., $\$ 3.00$.

\section{Onion Sets}

Sets 32 lbs. to bushel-By parcel post. Yellow Bottom Sets-Qt., $30 \mathrm{c} ; 1 / 4$ bu., $\$ 1.40$; $1 / 2$ bu., $\$ 2.75$.

Red Bottom Sets-Qt., 30c; $1 / 4$ bu., $\$ 1.40 ; 1 / 2$ bu., $\$ 2.75$.

White Bottom Sets-Qt., 35c; $1 / 4$ bu., $\$ 1.50$; $1 / 2$ bu., $\$ 3.00$.

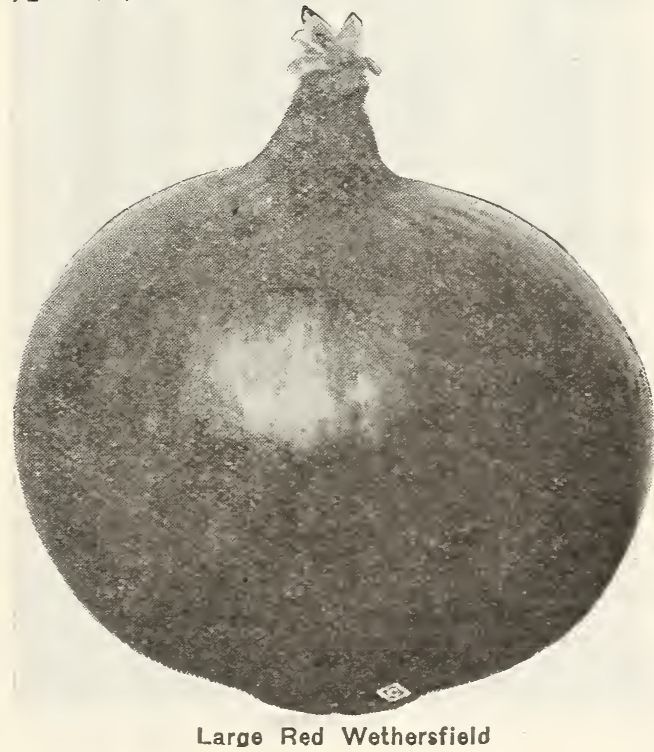

Large Red Wethersfield 


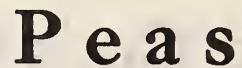

(We pay postage on all packets). Write for prices on larger amounts.

Weight of Peas: Wrinkled varieties, 56 pounds per bushel; smooth varieties, 60 pounds per bushel.

Culture.-The pea is hardy and endures cold well, either in or above ground. The small seeded early sorts, such as Alaska and First and Elest, can be sown while frost is yet in the ground, while large and sweeter peas sown at the same time, would rot in the ground. Sow some of the early, second early, and late varieties at intervals of about two weeks apart, and your table will be supplied with delicious peas for a long time.

Dwarf growing peas need no support; tall growing 'sorts should be trained to wire trellises or supported by brush. Wrinkled peas are the sweetest, and are recommended for the home garden.

A light warm soil is best adapted for very early peas, and heavier soils for late sorts.

The dwarf varieties can be planted in rows 12 to 18 inches apart, and the tall ones three feet. Larger pods and more of them will be produced if the seed be planted in trenches three to six inches deep and covered with only one or two inches of soil; when the plants are five or six inches high fill the trench level with the surface; this will secure deep rooting, prevent mildew and prolong the bearing season. If the peas be covered to the full depth at first or if water be allowed to stand in the trenches they will not germinate or grow well.

\section{Early Varieties}

Alaska or Earliest of All-Earliest and best of all early smooth varieties. A smooth, blue Pea, which in evenness of growth of vine and early maturity of the pods is unequaled by any other extra early Pea. Vines two to three feet high, bearing four to seven long pods, which are filled with medium-sized, bright green Peas of excellent flavor. Postpaid: Pkt., 5c; 1/4 lb., 10c; $1 / 2$ lb. 15c; ib., 25c; 2 lbs., 45c;

American Wonder-One of the most popular and best of the early wrinkled sorts. A great favorite for family use. Has stout, branching vines, covered

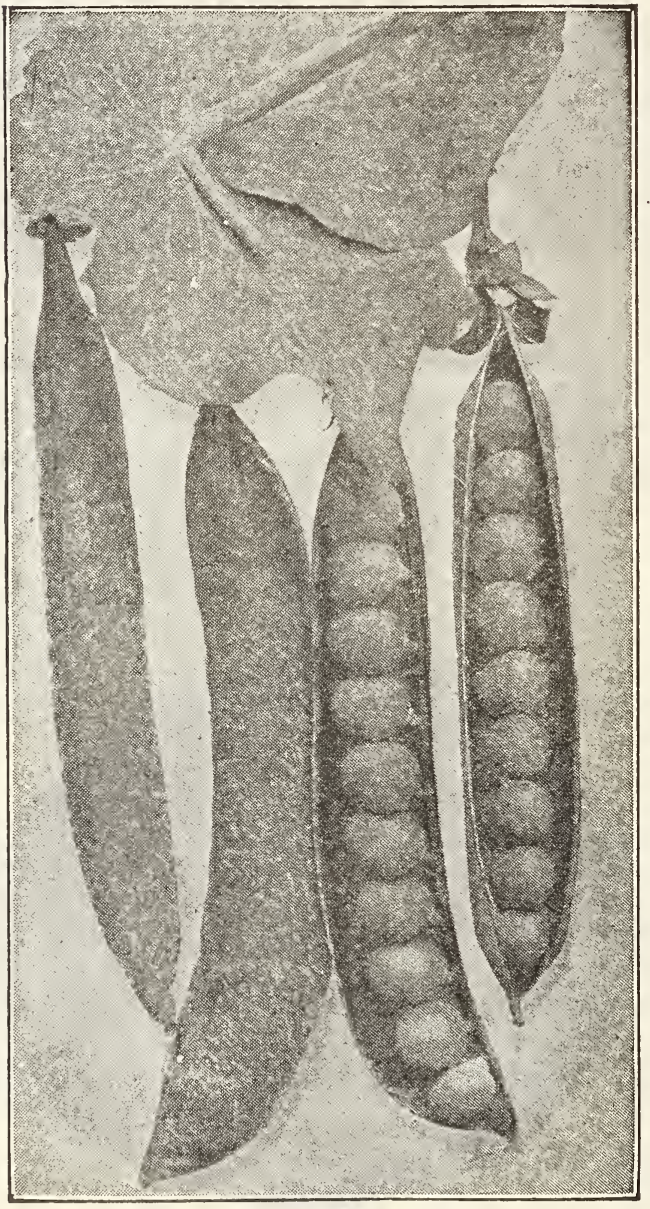

Alaska with well filled pods containing seven or eight large, exceedingly sweet, tender and well flavored Peas; height 10 to 12 inches. Pkt., 10c; lb., 35c; 2 lbs., postpaid, 65c.

Nott's Excelsior-An extra early dwarf, green, wrinkled sort. The Peas are superior in sweetness and quality; an ideal family and market Pea. It is fully as sweet and delicious as the American Wonder, and grows one-half tailer. Pods are larger and it is far more productive than the Premium Gem, and it is within a day or two as early as the first early smooth Pea. Pkt., 10c; 1/2 lbs., 25c; Ib., 40 c.

Premium Gem-Height one foot; early and prolific; a type of and an improvement on the McLean Little Gem; pods long and of dark green color. The most popular sort for family use. Pkt., 10c; lb., 30c; 2 lbs., postpaid, $55 \mathrm{c}$.

Ebbert Seed Co.'s Peacemaker-The most popular high quality extra early, wrinkled Pea. This remarkable Pea is not only large and of best quality, but is within two or three days as early as the small, round, extra early sorts. Peacemaker is a wrinkled Pea, growing about 30 inches high; the pods are of a bright green color measuring four inches or more in length, as large as Telephone, well filled with luscious Peas, 8 to 10 or more in a pod. Pkt., 10c; lb., 30c; 2 lbs., postpaid, $55 \mathrm{c}$.

\section{Second Early and Main Crop Varieties}

Seeds grown under Irrigation produce strong plants.

Dwarf Champlon-Dwarf or bush of the old favorite Champion of England. The best of all late peas. Grows about 15 inches high, stiff stalked and close jointed. Literally headed down with big, fat pods. Peas large and most delicious flavor. If you want a really sweet, heavy yielding, late Pea that will not need stakes, this is the one. Pkt., 10c; Ib., 30c; 2 lbs., postpaid, 55c.

Dwarf Telephone, Carter's Dalsy-A very tine second early dwarf Pea with immense pods and Peas. A magnificent sort. The self-supporting, stout plants are fairly loaded with large bright green pods, which are always well filled, each pod containing from seven to nine Peas, of a bright green color, tender and of most delicious flavor. One of the finest dwarf green wrinkled Marrow Peas in cultivation, and one that ought to be grown in every garden. 'Pkt., 5c; Ib., 40c; 2 lbs., 750, postpaid.

Everbearlng-Grows about 20 inches high, pods of good length; Peas very large, wrinkled, and in quality unsurpassed. For continuance and profu. sion of bearing this variety is unexcelled. Pkt., 10c; Ib., 30c; 2 lbs., postpaid, $55 \mathrm{c}$. 
Horseford's Market Garden-A very tine secondearly green wrinkled variety, not only good for family gardens but for canners, and especially market gardeners' purposes. Vines two feet high; exceedingly prolific; pods are of medium size and well filled with Peas of finest fiavor. Pkt., 10c; Ib., 30 c; 2 lbs., postpald, 55c.

Champion of England-One of the best late Peas for the market gardener or grivate garden. One of the richest and best flavored Peas grown and very productive. Height four or five feet, seed whitish green and much shriveled. Pkt., 10c; Ib., 30c; 2 lbs., postpald, 55c.

\section{Tall Telephone Pea}

A strong, luxuriant-growing, main crop variety, attaining $a$ height of about $4 / 2$ feet. Exceedingly prolific, averaging 18 pods to the stalk, while up to 24 the stalk is not uncommon. The pods, the largest of all varieties, are packed with immense wrinkled Marrow Peas, 6 to 8 being the average, while 10 to 12 to a pod are frequently found. The quality is superb, rich, sugary and meltingly tender. For family use the Telephone $\mathrm{Tea}$ is without a peer. Pkt., 10c; Ib., 30c; 2 lbs., pestpaid, 55c.

Improved Stratagem-Pods are of immense size, filled with large, dark green, wrinkled Peas; of the finest quality; vine medium beight, but very stocky, with very broad, light green, leaves, and bearing an abundance of large handsome rods. Pkt., 10c; Ib., 30c; 2 Ibs., postpald, 55c.

Yorkshire Hero-One of the largest, sweet, wrinkled kinds, vines strong and spreading; pods of good size and well filled; much in use, and has enjoyed a long popularity; medium late, bears a long time; height $2 \frac{1}{2}$ feet. Pkt., 5c; lb., 25c; 2 lbs., $40 c$.

White Marrowfat-Grows four to five feet in height. Pods large, round, light green and well filled. Excellent for summer crops, but of inferior quality. Pkt., 10c; Ib., 30c; 2 lbs., postpald, 55c.

Black-Eyed Marrowfat-The best of the Marrowfat varieties. Tall, hardy, and productive. Pkt., $10 \mathrm{c}$; Ib., 30c; 2 Ibs., postpaid, $55 \mathrm{c}$.

Dwarf Gray Sugar-Height 15 to 20 inches. Blossoms purple. Is used either shelled or cooked in the pod, like string beans, and when young is very tender and sweet. It is but little known in this country, while abroad it is considered a great relish. Pkt, 10c; Ib., 30c; 2 Ibs., postpald, $55 \mathrm{c}$.

Gradus-The earliest wrinkled variety. This large podded, early, prolific variety has won the hearts of market gardeners in every market. Vines very vigorous and robust, growing to about 3 feet. An abundant producer, bears continually throughout the season. Exceedingly early for a wrinkled variety, only a day or two lacer than the earliest small, smooth sorts. Pods very large invariably well filled with from six to nine sweet, luscious, tender wrinkled peas of large size and delicious flavor. The peas remain tender and sweet for some time after they are large enough to use. Pkt., 10c; Ib., 40c; 2 Ibs., 70c, postpald.

\section{Peppers}

Culture-Pepper seed requires heat for germina. tion. The seed should be sown early in hotbeds or boxes in the window, or may be sown in the open sround about the middle of spring. When two inches high, set in rich soil two feet apart in rows 2\% leet apart. Hoe often.

Now Sweot Uprlght Salad-The fruits are borne stifny erect, and form at each fork of the branches. Color a bright shiny green, which turns to a waren red when ripe. As early as the Sweet Bell or Bull-Nose, with heavier fruit, much thicker flesh and oreatly superior in navor. Pkt., 10c; $1 / 2$ 0z., 30c; 02., 50c; $1 / 4$ lb., $\$ 1.50$.

Chinese Giant-Largest and finest Pepper. The plant is about two feet high, of strong, vigorous srowth, stocky in habit, very productive, earlier than the Ruby King. The truit averages four inches in diameter, and is of a bright glossy scarlet when ripe. Flesh is unusually thick and very mild. The inmense oize and it brilliant color renders it vers

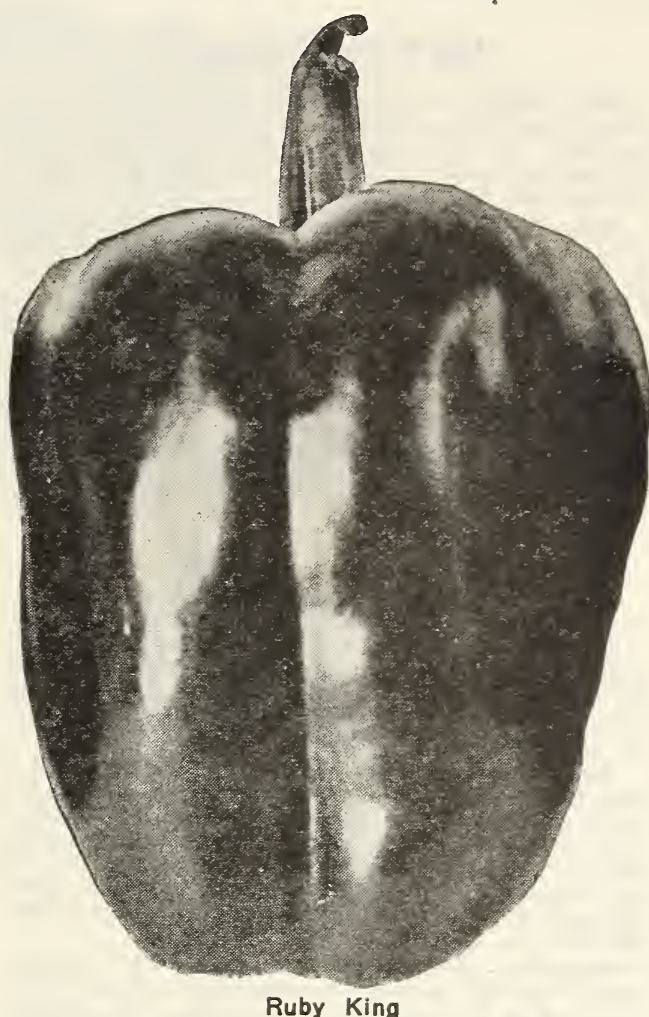

attractive and will cause it to sell readily in the market. Pkt., 10c., 0z., 50c; 1/4 lb., \$1.75; lb., $\$ 6.50$.

Ruby King-A handsome and very productive variety. Fruits bright ruby-red color, which grow to six inches long by three to four inches through. So mild is their flavor that they can even be sliced and eaten with vinegar like tcmatoes or cucumbers. Pkt., 10c; 0z., 50c; 1/4 Ib., \$1.75; Ib., \$5.50.

Largo Boll or Bull Nose-Best known sweet red sort. Height two feet. Ripens early and is very prolific. Fruits of good size, about three inches long and two inches through. Extra choice stock. Pkt., 100; 02., 50c; 2 02., 85c; 1/4 lb., \$1.40; Ib., $\$ 5.00$.

Ruby Glant-A beautiful variety, being a crose between the Ruby King and the Chinese Giant and the splendid shape of the Ruby King. Flesh mild and sweet, making a good salad sliced and served with tomatoes. Very popular both in the home and market garden. Pkt., 10c; 0z., 50c; $1 / 4$ lb., \$1.75; Ib., $\$ 650$.

\section{New Sweet Pepper Neapolitan Salad}

Earllest of All Large Mild Red Peppers.

The introducer says: "The strong, vigorous plants grow 2 feet high by 18 inches across; they are completely laden with lange handsome fruits and bear continuously until frost. Single plants carry from 35 to 50 marketable frults at one time. Grow upright until they become so heavy that their own weight turns them down. The skin and flesh are bright red; thick meated, sweet and 'mild as an appla." Pkt., 10c; 0z., 50c; lb., \$7.00.

Sweet Mountain or Mammoth-Much like the Large Bell, but larger and milder. Fruit thick and sweet. Fine for making stuffed mango pickles. Pkt., 5c; oz., 25c; 2 oz., $40 \mathrm{c}$; 1/4 lb., $75 \mathrm{c}$.

Golden Dawn Mango-Plants quite dwart but very prolific. Fruit medium size and of inverted bell shape, rich golden yellow color, with very thick weet, mild flavored neab. Pkt., 50; 0z., 200; $1 / 4$ Ib., 600 . 


\section{PEPPERS-Con't.}

Red Cherry-An ornamental useful variety, the plant being tall and bearing frofusely small, bright red fruit. Fruit is small, ro und, very hot and largely used for pickles. Pkt., 5c; oz., 30c; 2 oz., 55c; $1 / 4$ Ib., 90c; lb., $\$ 3.25$.

Red Chili-A rather small, bright red variety about two inches long and pointed. Pods are used in making chili sauce and very pungent and hot. Pkt., 10c; 0z., 40c.

Long Red Cayenne-The true Cayenne; hot and pungent. Pkt., 10c; 0z., 40c.

Anaheim Chili Pepper-Mainmoth "Chili Pepper." Stalks grow from two to three feet high, supporting the Peppers well off the ground. Average plant bears 30 to 40 Peppers from 6 to 10 inches. Pkt., 10c; oz., 40c.

\section{Pumpkin}

Culture-Usually planted ainong corn, in bills $8 \times 8$ feet. Plant any time during May. When the frost has killed the vines, cut off the stems a few inches from the fruit and store in a ciry place, using care not to bruise them when handling.

Small Sugar or Pie-This is the small pumpkin that has made the New England states famous for their pumpkin pies. A handlsome prolific variety; fruits of small size, averaging about 10 inches in diameter, of excellent keepirg qualities, flattened and slightly ribbed. Skin deep orange-yellow, flesh fine grained and sweet. Pkt.. 5c; 0z., 10c; 2 oz. 20 c; $1 / 4$ lb., 30c lb., $\$ 1.00$.

Improved Green-Striped Cushaw - A crooked necked variety, with green and white striped skin. The flesh is of rich yellow color, solid, fine-grained, very thick and sweet. Pkt., 5c; 0z., 15c; 2 0z., $25 \mathrm{c}$; 1/4 Ib., 40c; Ib., \$1.25.

Golden Cashaw, or Jonathan-Attractive and sells better than the old green striped sort. Large bottleshaped sort. Pkt., 5c; 0z., 10c; 2 0z., 20c; 1/4 lb., 30c; lb., \$1.00.

White Cashaw, or Crookneck-Fine for table use as well as for stock feeding. The fruits have a hard, creamy white shell, grow about 2 feet long, and the thick meat is of excellent quality. Pkt., 5c; 0z., 10c; 1/4 lb., 30c; Ib., \$1.00.

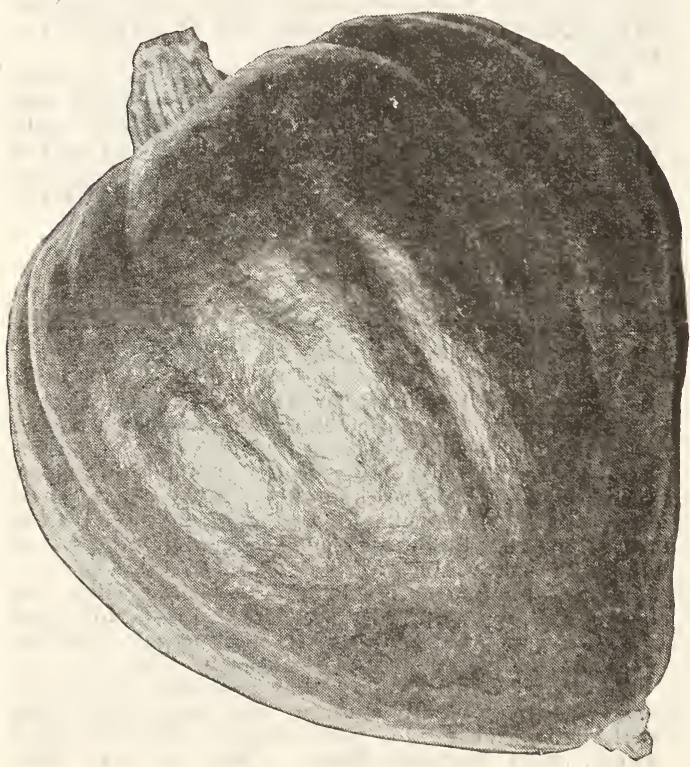

Tennessee Sweet Potato
KIng of the Mammoths, of Jumbo-Thls is the very best genuine strain of the true Mammoth Pumpkin-Fruits grow to enormous size, sometimes reaching two feet or more in diameter, and from one hundred to two hundred pounds in weight. Salmon-orange skin, very thick, bright yellow flesh which is fine grained, tender, and of excellent qual. ity for pies. Pkt., 10c; 0z., 15c; 1/4 lb., 50c; lb., \$1.50.

Connecticut Field-Large Cummon Yellow Field -The common Yellow Field Pumpkin, so very largely cultivated by our farmers for stock feeding. Is immensely productive and very hardy. Pkt., 5c; 0z., 10c; 1/4 lb., 25c; lb., 85c.

Large Cheese, or Kentucky Field-A very large, flattend variety, averaging about two feet through. When ripened the skin is a rich cream color. Flesh yellow and of fine quality. Fkt., $5 \mathrm{c}$; 0z., 10c; 2 0z., 15c; $1 / 4$ lb., 25c; lb., 75c;. By freight or ex. press at purchaser's expense, $\$ 50.00$ per 100 lbs.

Japanese Pie-A new Pumkpin of Japanese origin; flesh very thick, fine-grained, dry and sweet; productive and very desirable for cooking. The seeds are particularly marked and sculptured in Japanese characters. Pkt., 10c; 0z., 15c; 1/4 lb., $50 \mathrm{c}$; Ib., $\$ 1.50$.

Mammoth Tours-Immense size; often weighs 100 pounds; oblong; skin green; good exhibition sort, or for feeding stock in winter. Fkt., $5 c ; 0 z ., 10 c ; 1 / 4$ Ib., 30c; lb., \$1.00.

Tonnessee Sweet Potato Pumpkin-An excellent variety for pies, pear-shaped, medium size, flesh and skin a creamy white, fine grained, very sweet and delicious; a first rate keeper; when cooked it appears like sweet potato but has a more delicious taste. Pkt., 10c; 0z., 15c; 1/4 lb., 50c; lb., $\$ 1.50$

Winter Queen or Winter Luxury-A superior pie Pumpkin, sniall, but enormously productive and an excellent keeper; shape slightly oval, about 10 inches in diameter; color golden-russet, finely netted; flesh deep golden, sweet and tender. Largo Pkt., 5c; 0z., 15c; 1/4 lb., 35c; lb., $\$ 1.25$.

\section{Parsley}

Parsley is used for seasoning soups and stews, for salads, and also very universally used for garnishing; succeeds best in a pich, mellow soil. $\mathbf{A}$ s the seeds germinate very sluwly, three or four weeks sometimes elapse before it makes its appearance. It should be sown early in the spring.

Champion Moss Curled-An excellent variety; the leaves are finely curled and of a dark green color; extra fine for garnishing and culinary purposes. Pkt., 10c; 0z., 15c; 1/4 Ib., 50c; Ib., \$1.00.

Dark Green Triple Curled-Bright emerald color, extremely fine curled. Pkt., 10c; 0z., 15c; 1/4 lb., 50c; Ib., $\$ 1.00$.

Fern-Leaved-As its name indicates, this variety is most beautiful in form and color; valuable for garnishing, and also as ar ornamental foliage plant for borders of beds. Pkt., 10c; 0z., 15c; $1 / 4$ lb., 50c; lb., $\$ 1.00$.

Fine Double Curled-A curled variety having crimpled leaves. It is used mostly for garnishing. Pkt., 10c; 0z., 15c; $1 / 4$ lb., 50c; lb., $\$ 1.00$.

\section{PARSNIPS}

Parsnips succeed best in deep, rich soil. Sow as early in spring as weather will admit, in rows 15 inches apart. When the plants are two inches high thin out to five or six inches in the row. As they are improved by frost a part of the crop should be left in the ground for spring use.

Improved Hollow Crown-Has long been a favorite on account of its excellent table qualities. A great cropper and considered the best for general cultivation. The roots are long, smooth, tender and very sugary. Pkt., 10c; 0z., 15c; 2 oz., 20c; 1/4 lb., $25 \mathrm{c} ;$ ib., $\$ 1.00$.

Improved Guernsey-An improved strain, whiah has given general satisfaction. The roots do not grow so long as those of the Hollow Crown, but are of greater diameter and more easily gathered. Ot excellent quality. Pkt., 10c; 0z., 15c; 2 oz., 20c; $1 / 4$ Ib., 25c; Ib., \$1.00. 


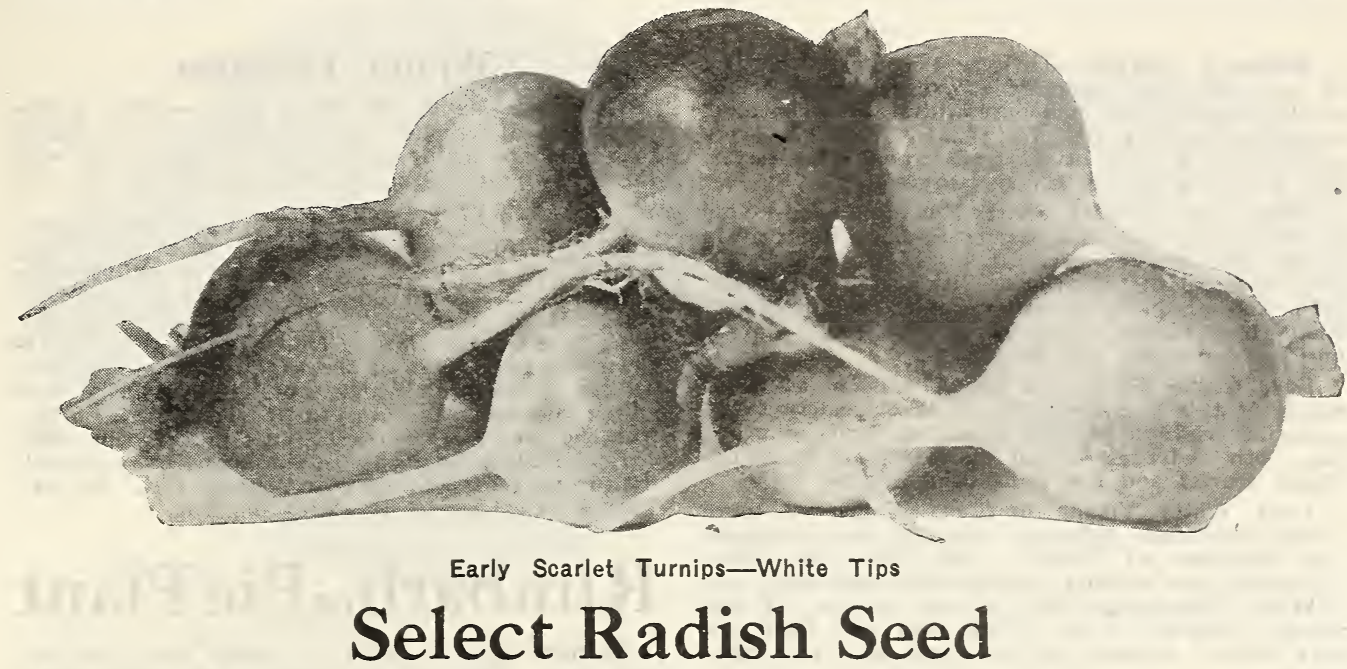

Our Radish seed is grown for us under contract, from the finest French stocks, and is sure to give satisfaction.

The radish is one of the most profitable crops to grow for market or private garden. It is in demand at all seasons of the year, especially in early spring. Radishes must make a rapid growth to be crisp and tender.

THE SECRET IN GROWING RADISHES.-First they should be grown on light, quick soil. Second, they should be given plenty of water, and last, but by no means least, the right kind of seed should be sown. Radishes grow very quickly, and if not supplied with plenty of water are apt to be pithy.

Culture-For early use seed should be sown in the hotbed, in drills three or four inches apart and half an inch deep. For open ground sow as early 28 weather conditions permit. As soon as the first leaves appear, sprinkle with soot or ashes to save them from the turnip fly. The winter radish should be sown about the middle of summer, and makes its best growth in autumn.

\section{Our New Radish-Half White Scarlet Turnip}

This new Radish is a remarkably attractive variety. The white tip extends nearly half way up the root. The top is a bright scarlet which makes 2 beautiful contrast. A splendid forcing variety, makes a rapid growth. Small tap root; mild and crisp.

This is the variety that market gardeners have been seeking for years and it will fill a long felt want. Everyone should try this splendid new Radish.

Prices on all Radish Seed (except where otherwise noted): Postpaid: Pkt., 5c; 0z., 10c; 1/4 lb., $30 \mathrm{c}$; lb., $75 \mathrm{c}$.

\section{Extra Early Olive Shaped}

French Breakfast-A medium sized Radish, olive shaped, with small top; of quick growth; very crisp and tender; of a beautiful scarlet color, except near the root, which is pure white. A splendid variety for the table on account of its excellent quality and attractive color.

Early White Olive Shaped-Clear, white, crisp and mild flavored.

\section{Early -Turnip Shaped Radishes}

Early Scarlet Globe (Vick's)-Unequaled by any other sort. The roots of this variety are slightly olive-shaped, a rich, deep scerlet in color; flesh white and tender. We specially recommend this to gardeners whose markets ciemand a large lirat early forcing Radish.

Earllest White Turnip-Like the scarlet in shape, but in color pure white. It is later and will bear beat longer without becoming spongs.

Early Scarlet Turnip-One of the earliest varieties, with very small top. Brightly colored akdo and crisp, white flesh.
Scarlet Turnip, Whlte Tipped (Rosy Gem)-One of the most popular and attractive short varieties. It is globe-shaped, bright rose carmine with bottom and tip clear white, stems and leaves small. Very valuable for forcing as well as for the house garden and market.

Non Plus UItra, or Early Deep Scarlet Turnip Forcing-An excellent extra early forcing radisb. Root small, nearly round; color bright scarlet. Top very small; flesh white, crisp and well flavored. One of the most handsome of the forcing sorts.

Crimson Giant-This radish is an entirely new type and differs radically frurn all varieties hitherto in cultivation, in so far as its roots attain more than double the size of those of other forcing varieties, without getting pithy or hollow. It is very early notwithstanding its size. Color crimson, flesh pure white, of the best quality. Fine for outdoors and forcing. The seed should be sown very thinly to permit full development of the roots. Pkt., 5c; 0z., 10c; 1/4 lb., 30c; lb., \$1.00.

Prices on all Radish Sead (except where otherwise noted): Postpaid: Pkt., 5c; 0z., 10c; 1/4 Ib., 30c; lb., 75c.

\section{Long Varieties}

The Best Radish for Home Garden.

New White Icicle, the Finest Eating White Radish-The finest and longest of the very early pure white varieties. Although a long radish of good size, it becomes fit for use almost as early as the small round sorts. The roots are straight, smooth and pure white in color. The flesh is almost transparent, brittle as glass, very tender and fine flavored.

Brlghtest Long Scarlet-A new variety, ready for use in ubout 25 days after sowing; color remark. ably bright, firey scarlet, slightly tipped with white; flesh crisp and tender. This is a choice radish. Try it.

Cincinnatl Market-This variety originated in the vicinity of Cincinnati, Ohio, and is one that will meet your expectations in every particular. The tops are small, and under favirable conditions the roots attain a length of 6 to 7 inches. They are smooth and free from any fibrous roots and their attractive scarlet-colored skin is unusually thin. The flesh is fine, crisp and rather transparent. Fit for use in 25 days from time of sowing and ro main in good condition until fully grown. 
Beckert's Chartler-This is the most beautiful of all the long summer radishes; color bright scarlet, shading off to a pure white at the bottom; a decided novelty and worthy of a place in every garden; it is very crisp, tender and mild flavor, and if left, grows to a very large size.

Early Long Scarlet Short Top, Improved-This is undoubtedly the best standard variety for private garden and market use. It grows 6 or 7 inches long, half out of the grousd. It is very brittle and crisp and of quick growth. Color, bright scarlet; small top, tapers regularly to the root, and is uniformly straight and smooth.

Rosy Gem-We have a very clean and beautiful strain of this popular sort. It is extremely early, maturing in 25 days, and is largely used for grow. ing, both under glass and outdoors. It is round, bright scarlet and has a handsome white tip.

Long White Vlenna or Lady Finger-A purt hite, beautifully tapering radish of rare crispness ad freshness of flavor. This, like the White trasburg, is a summer radish rather than early one.

White Strasburg-This variety is one of the popular summer kinds. Both skin and flesh are pure white. Remains tender longer than any other variety.

Prices on all Radish Seed (except where otherwise noted): Postpaid: Pkt., 5c; 0z., 10c; 1/4 Ib., 30c; lb., 75c.

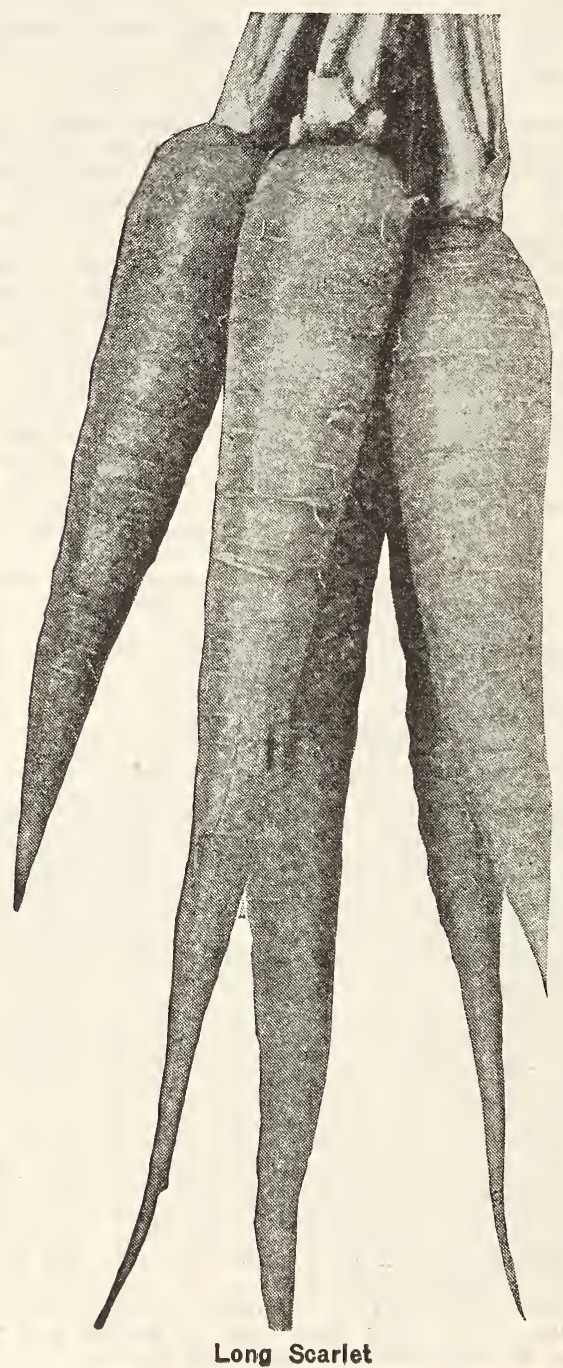

\section{Winter Varieties}

Californla Mammoth White China-This is the largest of all radishes. Roots grow 10 to 12 inches long and are solid, tender and crisp. Keeps well through winter. Pkt., 5c; 02., 10c; 2 0z., 15c; 1/4 lb., 25c; Ib., 80c.

Scarlet China, or Chlna Rose-A fine winter sort; root a half-long stump of from 2 to 3 inches; scarlet and pink in color, tipped with white; quite aalaole in market during winter. Keeps perfectly. Pkt., 5c; 0z., 10c; 2 oz., 15c: 1/4 lb., 25c; lb., 80c.

Long Black Spanish (Winter) - This variety is sown the latter part of the summer for winter use: attains a good size and should be gathered and stored the same as turnips; will keep until spring. Pkt., 5c; 02., 10c; 2 02., 15c; 1/4 Ib., 25c; lb. $80 \mathrm{c}$

Round Black Spanlsh-Of similar nature and quality to the Long, differing in shape. Pkt., $5 \mathrm{c}$; 0z., 10c; 2 02., 15c; $1 / 4$ lb., 25c; 1b., 80c.

\section{RhubarborPiePlant}

Culturo-Sow in drills 18 inches apart and one inch deep. Thin out the plants to six inches apart. In the fall prepare the permanent bed by trenching two feet deep, mixing a liberal quantity of manure with the soil. Into this set the plants about five feet apart each way. The stalks should not be cut until the second year.

Early LInneaus-Early, cortaining large stalks and leaves, and \& rapid and satisfactory grower. Makes a delicious and highly aromatic sauce, and has no superior as a pie variety. Pkt., 10c; 0z., 20c. Victoria-The most popular variety; comes quite true from seed. Pkt., 10c; 0z., 20c.

RHUBARB ROOTS IN SEASON-Write for prices.

\section{Spinach}

Culturo-Should be planted in very rich ground, the richer the better. Sow in drills 12 to 18 inches apart and thin to about six inches apart when the leaves are an inch wide; should be cut while young and tender. For early spring use sow early in autumn and protect the plants with a light covering of leaves or straw, cr plant as soon as the land can be worked in the spring.

Spinach is very hardy, extremely wholesome and palatable, and makes a delicious dish of greens, retaining its bright green color after cooking. In the South spinach can be grown through the winter with very little or no covering.

Bloomsdale Savoy-The variety most generally used in the East, and especially throughout the South for shipping. Leaves large, round and thick, very much savoyed and rich deep green. One of the earliest varieties. Seed round. Pkt., 5c; 0z., 10c; 2 oz., 15c; 1/4 ib., 20 ; ib., 50c.

Victoria-A long-standing variety with round, slightly savoyed leaves. Deep green and hardy. Forms good, edible leaves early and continues to produce leaves for a long period. Pkt., 5c; 0z., $10 c ; 2$ 02., 15c; 1/4 Ib., 20 c; lb., 65c.

Improved Thick-Leaved, or Long-Standing-Leaves large and thick. Somewhat crumpled. Does not run to seed as early as other varieties. Pkt., $5 \mathrm{c}$; $02 ., 100 ; 2$ 02., 15c; 1/4 Ib., 20c; Ib., 50a.

New Zealand-This sort is sown tr, supply the place of ordinary spinach during the bottest months of the year; or in dry, arid localities. The leaves are eaten boiled like those of other varieties. Pkt. 5c; 0z., 10c; 2 0z., 20c; 1/4 lb., 30c; Ib., \$1.00.

Prickly or Winter-A hardy variety used for fall sowing, with very slight protection it will withatand the severest weather. Pkt., 5c; 0z., 10c; 2 0z., 15c; I/4 Ib., 250; Ib., 750 .

\section{A Big Home Garden}

is the best and biggest money saver and the largent producer of money saving food supplies you cen have. Plant a good big home garden with EBBERT SEED Co.'S reliable seeds. 

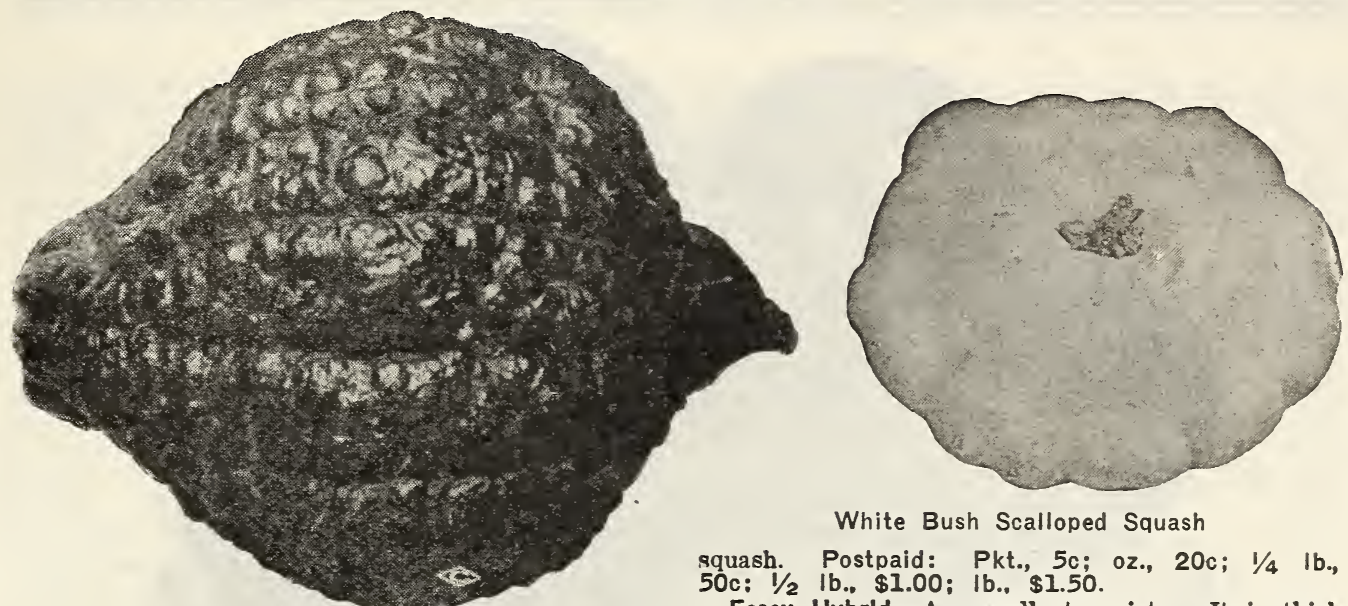

White Bush Scalloped Squash

squash. Postpaid: Pkt., 5c; 0z., 20c; 1/4 lb., Esex 1 ., \$1.00; Ib., \$1.50.

Hubbard Squash

\section{Squash}

Culturo-Sow in hills in the same manner and at the same time as cucumbers and melons, bush varieties two to four leet apart, running kinds six to nine. Plant a dozen seeds in each hill, and when danger from the "bugs" is over, pull up all but three or four. Winter squash should be ripened thoroughly or they will not keep through the winter.

\section{Summer Squash}

Early White Bush, or Patty Fan-The best early variety. The plants are of the true bush form, and produce fruit early in the season. Largely grown in the South for shipment to the Northern markets. Pkt., 5c; 0z., 15c; 2 oz., 25c; $1 / 4$ lb., $40 \mathrm{c}$; Ib., $\$ 1.50$.

Bush Fordhook-A new busl type of the original Fordhook, unequaled in quality and delicious sweetness by any variety whether for summer or winter use. The young tender fruits are prepared and cooked like other summer squashes, or stored before frost in a warm, dry place, furnish winter squash for table use until the next crop is ready. Pkt., 5c; 02., 15c; 2 0z., 25c; 1/4 lb., 40c; lb., \$1.00. Mammoth White Bush Scallop (Silver Custard) -An improved variety of the well known White Bush Squash, growing 12 to 15 inches across, of uniform shape and beautiful white color. Very early and prolific. Pkt., $5 c$; 0z., 20c; 2 oz., 35c; 1/4 Ib., 55c; lb., $\$ 1.75$.

Mammoth Yellow Bush or Golden Custard-This is a new dark rich golden yellow, scalloped bush Summer Squash, grows large, is not excelled in quality and is very productive. Pkt., 5c;0z., 15c; 2 0z., 25c; 1/4 Ib., 40c; lb., $\$ 1.00$.

Golden Summer Crook Neck-Plants of the true bush variety, early fruiting and very productive. Rich golden color, heavily warted rind, deep flesh of superior quality. An excellent summer variety; none better. Pkt., 5c; 0z., 15c; 2 0z., 25c; 1/4 lb., $40 c$; Ib., \$1.00.

\section{Autumn and Winter Varreties}

Boston Marrow-A popular variety with large, oval fruit. Skin bright, reddish orange, with light creamy netting, flesh orange. Fine grained and of excellent quality. This is the most popular variety for canning. Pkt., $5 \mathrm{c}$; 0z., J5c; 2 oz., $25 \mathrm{c}$; $1 / 4 \mathrm{lb}$., 40c: lb., \$1.25.

Delicious-The Best Flavored Squash In Existence -In size it resembles the Irubbard. In thickness of flesh it surpasses nearly every variety. The color is a dark orange. No other variety compares with it in its remarkable combination of fineness and compactness of grain, dryness, sweetness and exceeding richness in flavor. It is a fall and winter
Essex Hybrld-An excellent variety. It is thick meated with thin shell and is a splendid baking orange. Squash broad and round. Pkt., 5c; 0z., $15 \mathrm{c} ; \mathrm{l} / 4$ Ib., $30 \mathrm{c}$; Ib., $\$ 1.00$.

Proliflc, or Orange Marrow-The earliest of the fall varieties, and much sooner ripe than any other Marrow Squash. Very prolific, an attractive bright orange-red; it is a general fúvorite as its quality is the best. Pkt., 5c;0z., 20c; 2 0z., $35 \mathrm{c} ; 1 / 4 \mathrm{lb}$., 55c: Ib., \$1.75.

Red or Golden Hubbard-A perfect type of the Green Hubbard, except in color, which is a bright, deep orange-yellow, very showy and attractive. Flesh deep, golden-yellow, much richer in color than Hubbard. Pkt., 5c; 0z., 15c; 2 0z., 25c; 1/4 Ib., 40c; lb., \$1.25.

Improved Hubbard-The standard winter squash no better variety grown, more generally cultivated as a late sort than any other. It is of large size, often weighing from 9 to 10 pounds. Color, bluishgreen, occasionally marked with brownish-orange or yellow. Flesh fine grained, dry and of excellent flavor. Pkt., 10c; 0z., 20c; 2 oz., 35c; $1 / 4 \mathrm{lb}$. 55c; ib., $\$ 1.75$.

Chicago Warted Hubbard-Is similar in size and quality to the Hubbard. The vines are vigorous and productive, while the large, dark-olive green fruits are rather more heavily warted. Very handsome in appearance; an excellent keper and of splendid quality. Pkt., $5 \mathrm{c}$; 0z., 25c; 2 0z., $40 \mathrm{c}$; $1 / 4$ Ib., 75c; Ib., $\$ 1.25$.

Marblehead-This is an old variety that is still a favorite with many; one of the best keepers, has the hard shell and the color is a very dark green, flesh a rich yellow color. Pkt, 5c; 0z., 10c; 2 0z., $20 \mathrm{c}$; $1 / 4 \mathrm{lb}$., 30c; lb., $\$ 1.00$.

Mammoth Chill-The largest of all squash; grows to an enormous size. One of the most profitable sorts for stock feeding. Keeps well throughout the winter. This variety is also extensively grown for fair exhibits. Oz., 15c; 2 oz., 25c; 1/4 Ib., 40c; lb., $\$ 1.00$.

Sibley or Pikes Peak Squash-See specialties on page 7 for description and price. A vegetable of special merit; give it a trial.

\section{Salsify or Vegetable Oyster}

Culture-Sow early; when plants are of sufficient height, thin to four inches. It is unfortunate that this valuable vegetable does nut take a higher place in the esteem of our gardeners. It requires practically the same treatment as parsnips, while for fall and winter use it is much superior, making, as it does, a satisfactory substituite for oysters, hence is sometimes called "Oyster rlant."

Mammoth Sandwich Island-The very best variety grown. Is fully twice the size of any other variety and of better quality. The leading variety among both market and private gardeners. Pkt., 10c; 0z., $20 \mathrm{c} ; 1 / 4 \mathrm{Ib} ., 75 \mathrm{c}$. 


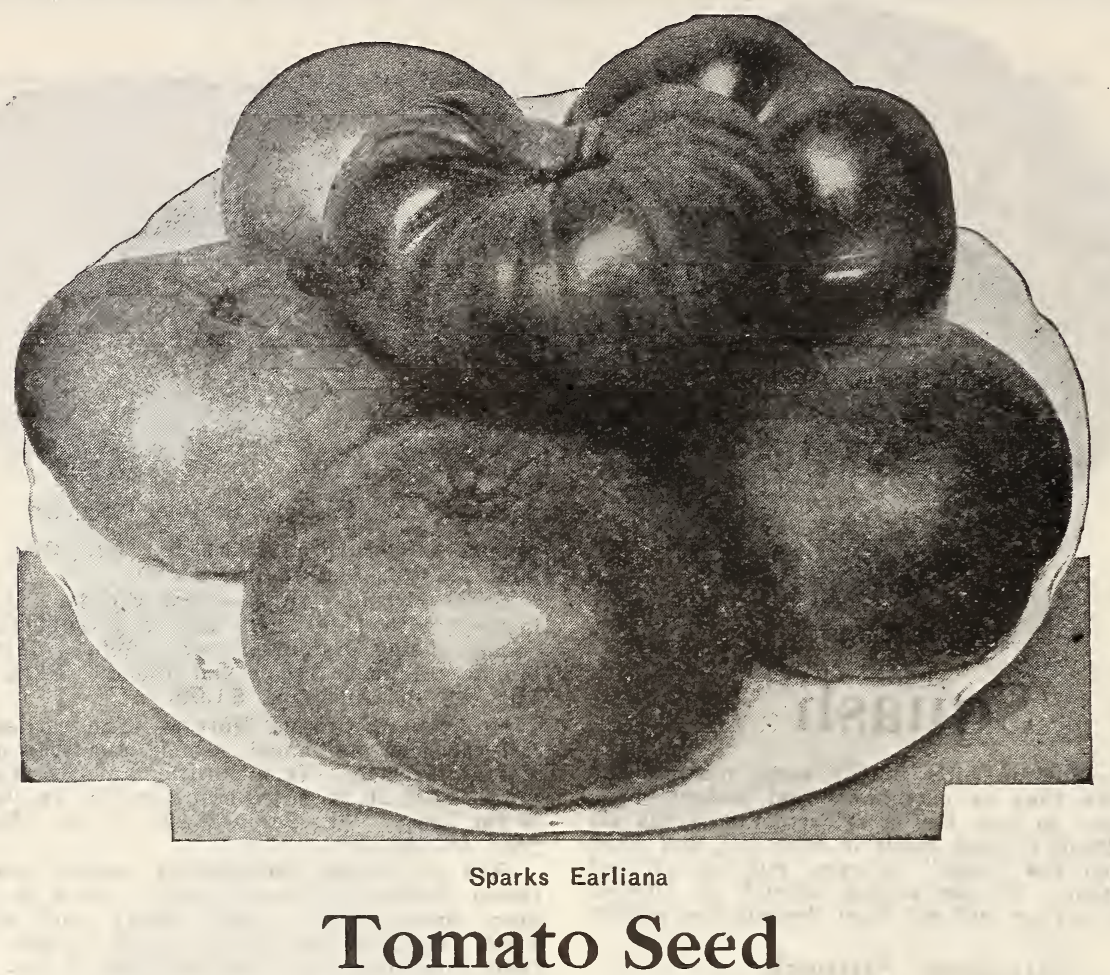

We do not use canning factory seed. Our Tomato seed has all been grown by Tomato Speclalists, who plant for seed only.

Culture-Tomatoes do best on light, warm, not over rich soil. Sow in hotbeds from six to eight weeks before they can be set out of doors, which is when danger from frost is past; when the plants have four leaves transplant into shallow boxes or cold frames, setting them four or five inches apart; give plenty of air and endeavor to secure a vigorous but steady and healthy growth so that at the time of setting in the open ground they will be strong and stocky. Even a slight check while the plants are small will materially diminish their productiveness. Transplant to the cpen ground when all danger of frost is past; setting the plants three or four feet apart each way. Transplant carefully and cultivate well as long as the vines will permit.

Dwarf Champion-Most popular dwarf variety in cultivation. Its stout, erect, bush-like growth enables it to withstand the strong prevailing winds. It grows about two feet high and stands quite erect without staking. In color and form the fruits are similar to the Acme. It is quite as early as any purple fruited tomato; :s very pcpular with Southern gardeners, as well as for home use. Pkt., 10c; oz., 40 c; 1/4 Ib., \$1.15; Ib., \$4.00.

Earliana (Sparks)-Probably no early tomato introduced in many years has attracted so much attention, and has so large a saie as Sparks' Earliana. Its solidity and fine qualities are fully equal to many of the best late sorts. The plant is of strong and vigorous growth, setting its fruit freely and in great abundance. The fruit is not only remarkable for its earliness, for its large size, perfect form, bright red color and delicious flavor. Pkt., 10c; oz., 45c; $1 / 4$ lb., $\$ 1.25$; lb., $\$ 4.25$.

Chalk's Early Jewel-The largest, smoothest and finest flavored extra early tomato in cultivation. Within a week to ten days as early as the famous Sparks' Earliana, while its more robust growth makes it a surer cropper in the warm Southern states. Vine vıgorous and very productive. Fruit deep scarlet red, smooth, of large size and excellent quality. Pkt., 10c; 0z., 70c; 1/4 Ib., \$1.15; Ib.. $\$ 4.00$.
The Bonny Best Tomato is fully two weeks earlier than Chalk's Early Jewel and as early as most strains of Earliana. A very vigorous grower; enormously prolific, setting 12 to 15 smooth, round globe shaped fruits in the crown setting of large size and excellent quality. Pkt., 10c; 0z., 35c; 2 0z.s 60c; $1 / 4$ Ib., $\$ 1.00$; lb., $\$ 3.50$.

Dwarf Stone Tomato-This is the largest Dwarf Tomato in existence. In havit of vine it resembles the Dwarf Champion, but is of stronger growth and is more erect. The fruit is similar to the Tall Stone in color (red), shape and practically in size. Specimens weighing one pound each are quite common. The season is fully as early as the Dwart Champion, but the fruits are double the size. The fruit is free from cracks at the stem end, solid, ripens evenly, and is of excellent quality. Pkt., $10 \mathrm{c}$; oz., 35c; $1 / 4$ lb., $\$ 1.00$; lb., $\$ 3.50$.

John Baer-An extra early scarlet fruited variety of superior merit. The vines sre very hardy and exceptionally productive. The fruits are the largest of the extra early sorts and are also most attractive in color. They are nearly round, smooth, firm and of excellent quality. It is one of the very earliest to ripen its first fruits and it continues to furnish marketable fruits much longer than other very early varieties. It is an invaluable sort for market garden varieties, shippers and canners. Pkt., 5c; 0z., 40c; 2 oz., 75c; 1/4 lb., \$1.10; lb., $\$ 4.00$.

Earlibell (New)-Earliest tomato known. For description see Specialties, page 7.

Beauty (Livingston's)-l'ire smoothest and best of the large purple sorts. Vines large, vigorous and heavy bearers; fruit large, uniform in size, very smooth, color of skin purplish pink; flesh light pink and of excellent flavor. A cecided favorite for either home market, shipping or canning. Pkt., 10c; oz., 35c; 1/4 Ib., \$1.00; Ib., \$3.50.

June Pink-An extra early selection from Earliana, differing chiefly in outside color, which is of the purplish-pink preferred in some sections to scarlet. The fruit runs uniform in shape and size about three inches in diameter, almost round, and borne in clusters. Flesh solid and fine. Pkt., 10c: oz., 40c: 1/a Ib., \$1.15: Ib., $\$ 4.00$. 
Livingston's Coreless-The most perfect shaped canning variety ever producnd. Large size, globe shaped, full at stem end, bright red, a strong grower and big cropper. Ripens all over at once and being almost free from green core it is an exceptionally fine slicing sort. Pkt., 10c; oz., 40c; 2 oz., 75c; 1/4 lb., \$1.25; in., $\$ 4.00$.

Livingston's Globe Tomato-This excellent tomato was first introduced in 1907, and described by the introducer as follows:

Round as a ball, smooth as an apple, with very little indenture about the stom, and very prolific. color bright scarlet, flesh rich crimson, and of the finest quality. The fruit is firm and solid, free from cracks, always smooth and of desirable size. It is quite early and very desirable for canning, as a large percentage can be put into the cans whole. For the market and home garden the Hummer is hard to beat. Pkt., 10c; oz., 45c; 1/4 lb., \$1.25; Ib., $\$ 4.25$.

New Matchless-One of the favorite canning and shipping varieties. The fruit a very rich cardinal red, firm and not liable to crack. They are very large size and grow uniform through the entire season. Good keepers. It is an exceptionally good main crop tomato. Pkt., 10c; oz., 30c; 2 oz., 55c : $1 / 4$ Ib., 90c; Ib., $\$ 3.00$.

New. Stone-The best main crop variety for all purposes, and largely used for canning. Vine tall and prolific. Fruit smooth, large and uniform. Color, bright scarlet. Pkt., 10c; 0z., 40c; 1/4 lb., $\$ 1.15$; Ib., $\$ 4.00$.

Golden Queen-A grand yellow variety of superior flavor; unsurpassed as a table variety. As smooth as any of the red varieties and of distinct rich tlavor. Pkt., 10c; 0z., 30c; 2 oz., 55c; 1/4 lb., 90c; ib., \$3.00.

Ponderosa-One of the largest varieties grown; very smooth, meaty and has few seeds. The color is brilliant scarlet crimson. Splendid sort for the home garden. Pkt., 10c; 0z., 60c; 1/4 Ib., \$1.75; lb., $\$ 6.00$.

\section{Small Fruited Tomatoes for Pickles, Preserves, Etc.}

Red Pear-Used for presorves and to make "tomato figs." Fruit bright red, distinct pear shaped and of excellent flavor.

Yellow Pear-Similar to the Red Pear, but of the rich. clear yellow color.

Yellow Plum-Fruit plum-shaped, of pure, deep yellow color; flesh yellow and finely flavored. Much esteemed for preserves.

Red Plum-Same as above, except color.

Red Cherry-Fruit small, about $\mathrm{5} / 8$-inch in diameter. perfectly round and smooth. Fine for pickles and preserves.

Yellow Cherry-This variety differs from Red Cherry in color only.

Peach-Desirable for preserving, eating from the hand or for table decoration. Fruit resembles a peach in shape and size; color a light terra cotta red; flesh tender and of good flavor.

Husk or Strawberry (Grourd Cherry, etc.) - Fruit golden yellow, size of a cherry. Fine for pies, preserves or eating from the hand.

Prices, any of the above varietles: Pkt., 10c; oz., $45 c$; 2 oz., 80c; $1 / 4$ lb., $\$ 1.25$; Ib., $\$ 4.50$.

\section{Tomato Plants}

We have in season strong hardy plants. Prices on application.

\section{Turnip}

Culture-Turnips prefer a light, sandy loam. Sow in rows, 12 to 18 inches apart, and half an inch deep. Thin out so that the plants stand four inches apart. For early use, sow as soon as the ground can be worked; for winter use, sow in August. Turnips are chiefly grown for autumn's cropping, because ordinarily they thrive better in cool weather; during the hot months they are apt to run to leaf and make seed rather than bulbs.

Early Purple-Top Strap Leaf-The leading standard American variety. Good for early spring and fall use. Color, red or purple above ground, white below. Pkt., 5c; 0z., 10c; 2 oz., 15c; 1/4 Ib., 25c; Ib., 75 c.

Extra Early White Milan-One of the earliest turnips in cultivation, pure white, excellent flavor, makes ranid growth; a great nıarket favorite. Pkt., $5 c$ oz., 15c; 2 oz., 25c; 1/4 lb., 40c; lb., \$1.00.

Extra Early Purple Top Milan-Earliest turnip in cultivation, fit for use a week sooner than others. Suitable for spring or fall planting. Bulb forms very rapidly, making but few and small leaves. The turnips are flat, smooth, white with purple top. Pkt.. 5c; 0z., 15c; 2 0z., 25c; 1/4 lb., 40c; Ib., $\$ 1.00$.

Golden Ball, or Orange Jelly-Medium yellow skin and flesh mild and fine flavored. Pkt., 5c; 0z., 10c; 2 oz., 15c; 1/4 lb., 25c; lb., 75c.

Yellow Aberdeen-Very hardy and productive; good keeper; globe-shaped; fine quality. Pkt., 5c; 0z., 10c; 2 0z., 15c; 1/4 lb., 25c; lb., 75c.

Early White Flat Dutch-(Strap-Leaved). This is a popular early turnip for table use. Matures only a week after the earliest Milan, but keeps much longer in fine condition. The skin is pure white, the flesh is mild and juicy. Pkt., 5c; oz., 10c; 2 oz., 15c; 1/4 lb., 25c; lb., 75c.

Purple Top Globe-Distinctly glebe-shaped, a good size; the color purple and white, being one of the best cooking varieties, ind a standard among gardeners. Pkt., 5c; 0z., 10c; 2 oz., 15c; 1/4 lb., $25 \mathrm{c}$; Ib., $80 \mathrm{c}$.

Amber Globe-Yellow flesh, firm, fine grain; very sweet; skin yellow, with green top; keeps well very popular in the South. Oz., 10c; 2 oz., 15c; 1/4 Ib., 25c; Ib., 75c.

Extra Early White Egg-The finest flavored of all early turnips and with favorable seasons is ready for table use in six weeks from sowing. Skin and flesh are pure snow white; solid, fine grain, sweet and a good keeper. Pkt., 5c; oz., 10c; 2 oz., 15c; 1/4 lb., 25c; Ib., 80c.

Early Snowball-A perfect globe-shaped whiteskinned turnip exceedingly productive; one of the best keepers of the white fleshed sorts. Pkt., 5c; oz., 10c; 2 oz., 20c; 1/4 lb., 30c; lb., \$1.00.

Pomeranian, White Globe-Very productive in good soil, roots frequently from 10 to 12 pounds. Good for table or stock feeding. Pkt., 5c; oz., 10c; 2 oz., 15c; 1/4 Ib., 25c; lb., \%5c.

\section{Rutabaga-Swedish Turnip}

Improved American Purple-Top-Leading yellow variety; very productive; sclid and of excellent flavor; the roots grow to a large size, and are of finest quality; not surpassed for stock feeding. Pkt. 5c; 0z., 10c; 2 oz., 15c; $1 / 4$ lb., 20c; Ib., 65 c.

\section{Peanuts}

Peanuts thrive and produce best on light, sandy, fertile soil, with a good clay subsoil. They possess long tap roots, which extend deep into the earth, drawing thence the nutriment, which is beyond the reach of any of our cultivat?d crops.

Spanish-The earliest variety, pods small, but remarkably well filled and solid. Can be cultivated with the plow. Because of its early habit and easy cultivation it is the best variety to grow for fattening hogs. Lb., 35c.

White Jumbo-The standard variety for roasting. Three times as large as the ordinary Spanish peanut. The nuts proper grow in fine double jointed hulls of beautiful white appearance, are from $3 / 4$ of an inch to 1 inch in length, and of fine flavor. An excellent variety, worthy of the highest recom. mendation. Lb., 35c, postpaid. 


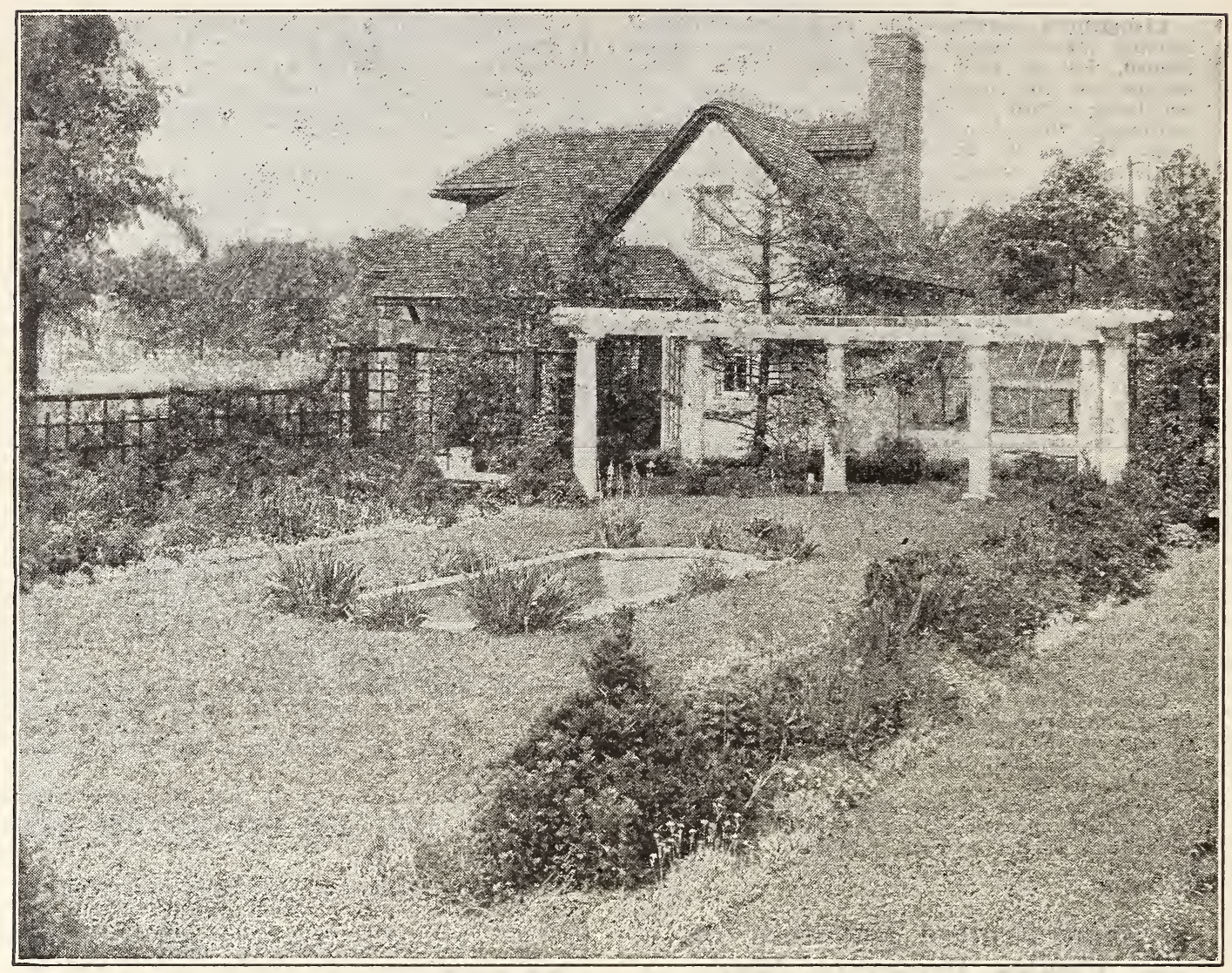

What Is More Attractive Than a Skilfully Planted Flower Garden.

\section{Ebbert's Select Flower Seeds}

\section{GENERAL DESCRIPTIVE LIST OF SELECT FLOWER SEEDS}

OUR FLOWER SEED LIST has been carefully revised, some new kinds added, and all the Inferior kinds cast out, so that there is nothing in the list but what is worthy of cultivation, and if reasonably cared for, will give satisfaction. Our aim is to offer nothing but the best and surest to please, a condensed list of leading kinds, and not the most bewildering and extensive. Any flower seed not offered in the following pages will be secured on short notice at the price quoted in other catalogs. include a fow packets with your Vegetable Seed Order.

A FEW SUGGESTIONS ABOUT SOWING, ETC.-We give here a fow general rules which will be helpful to beglnners. The soil best suited to flowers is a light, rich loam, which should be as fine and smooth as posslble. Should the soll be heavy, mix with sand to Ilghten It. Sow the seed either broadcast or in rows, and cover In proportlon to the slze of the seeds-a good general rule is to cover two or three times the size of the seed-and press the soll firmly. Small seeds cannut come up if covered too deep. Most of the flower seeds are so fine, that they should be sown on top of the loose ground, covered very lightly with fine ground or manure, and pressed down with a roller or the hand. Principal causes of failure in raising flowers are due to too deep sowing and lack of water at the proper time. As flower seeds in general are sown shallow, light, but frequent sprinklings are all that is needed. The main object is to keep the soil around the seeds always moist, as air and moisture are needed to insure good germination and to prevent the ground from getting a hard crust.

The letter "A" annexed to the name of varleties signifies Annual; "H. A.," Hardy Annual; "B," Biennlal: "P," Perennlal.

ANNUALS grow, bloom and die the first year from seed; BIENNIALS bloom the second year from seed and then die, though many if sown early in the spring, will flower the first year; PERENNIALS usually bloom the second year from seed, and continue to grow and bloom for many years; some will also bloom the flrst year if sown early.

\section{WE PAY ALL POSTAGE ON FLOWER SEEDS}

For $\$ 1.00$, seeds In packets may be selected to the value of $\$ 1.25$ For $\$ 2.00$, seeds in packets may be selected to the value of $\$ 2.60$ For $\$ 3.00$, seeds In packets may be selected to the value of $\$ 4.00$ Above offer applles to flower seed packets only. 


\section{LIST OF FLOWERS FOR SPECIAL PURPOSES EDGING AND BORDER PLANTS}

Abronia, Ageratum (dwarf), Alyssum Sweet, Asperula, Bellis, Candytuft, Centaurea, "Dusty Miller," Lobelia, Mignonette, Myosotis, Nasturtium (dwarf), Nemophila, Pansy, Portulacca, Snap Dragon (dwarf). Silene, Sweet William, Sweet Peas (dwarf).

\section{PLANTS FOR BEDDING AND IN MASSES}

Adonis, Amaranthus, Antirrhinum, Asters, Bachelor's Buttons, Balsom, Brachycombe, Cacalia, Calendula, Calliopsis, California Poppy, Campanula, Castor Beans, Carnation, Chrysanthemum, Clarkia, Cox. comb, Delphium, Digitalis, Four o'Clock, Gaillardia, Geranium, Heliotrope, Lantana, Larkspur, Linum, Mignonette, Nicotiana, Nigella, Phlox, Petunia, Pinks, Poppy, Salpiglossis, Salvia, Scabiosa, Sunflower (fancy), Stocks, Sweet Sultan, Sweet William, Verbena, Wallflower, Zinnia.

\section{CLIMBING PLANTS}

Adlumia, Ampelopsis, Bignonia, Canary Bird Flower, Clematis, Coboea, Cypress Vine, Gourds, Hop, Japanese Hyacinth Beans, lpomoea, Ivy, Morning Glory, Nasturtium, Sweet Heas, 'I'hunbergia, Wild Cucumber, Wistaria.

\section{Select Flower Seed}

Abronia Umbellata (A)-Handsome trailing plants, with clusters of sweet scented rosy pink flowers, resembling the Verbena. Pkt., 5c.

Abutilon (Chinese Bell Flower, or Flowering Maple) -P. Greenhouse shrub and profuse bloomer Valuable in the garden and an excellent house plant. Finest Mixed Varieties. $4 \mathrm{ft}$. Pkt., 10c.

Acroclinium (Everlasting) (H. A.)-Extensively used as a dried flower for house decorations. They should be gathered before fully open and tops hung downward to dry. $1 \mathrm{ft}$. Double Mixed, Pkt., 5c.

Adlumia Cirrhosa (Mountain Fringe, or Allegheny Vine) - Graceful hardy biennial climber with feath ery foliage like that of the Vaidenhair Fern, and tube-shaped flower of delicate rose, pink and white, which cover the plant. Grows $15 \mathrm{ft}$. high; desirable for covering trellises, stumps, etc. Pkt., 10c.

Adonis Autumnalis (Pheasarit's Eye) (H. A.) Showy annual of easy culture, with pretty, fine cut foliage, dark crimson flowers, lasts a long time. 1 ft. Pkt., $5 \mathrm{c}$.
Ageratum (Floss Flower) (H. A.)-One of the best bedding and border plants, blooming from early summer until frost. Flowers do not fade in the rain. $11 / 2 \mathrm{ft}$. Blue, pkt., 5c. White, pkt., 5c. Dwarf Mixed, 10 inches, pkt., $5 \mathrm{c}$.

Alyssum, Swoet (H. A.)-Orie of the best known annuals; used extensively for tordering and edging; also valuable for cutting. ilowers from early sum. mer till late fall.

Sweet Alyssum-The well-known fragrant white. Pkt., 5c.

Little Gem-Very dwarf; 4 inches, and spreading. They quickly become one miss of white, fragrant flowers, remaining in full bloom from spring to fall. Pkt., 1Oc.

Veitchii (Boston, or Japanese Ivy)-One of the best hardy vines for covering brick or stone build. ings; foliage dense, turning to scarlet in fall. 100 ft. Pkt., 5c.

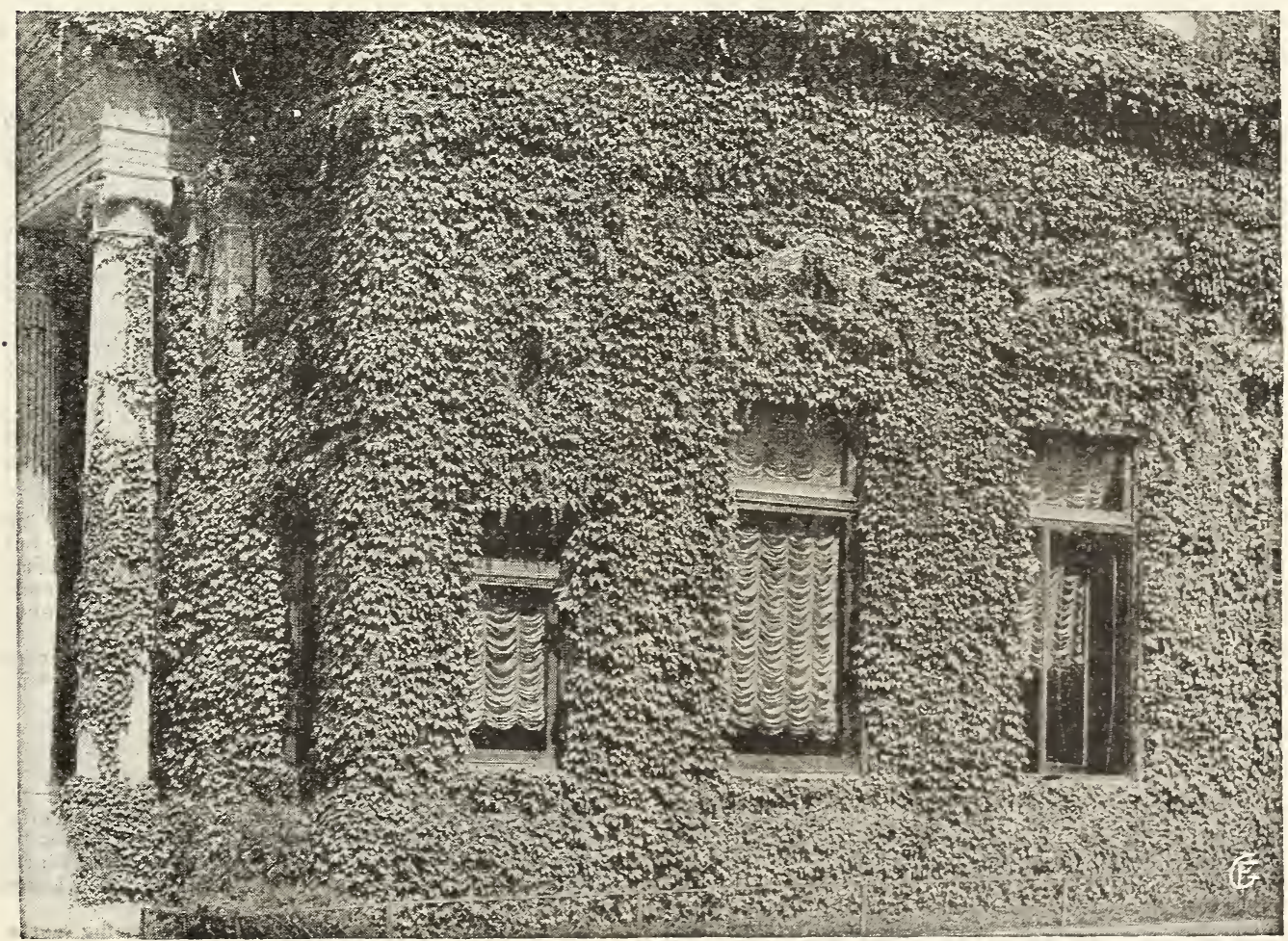




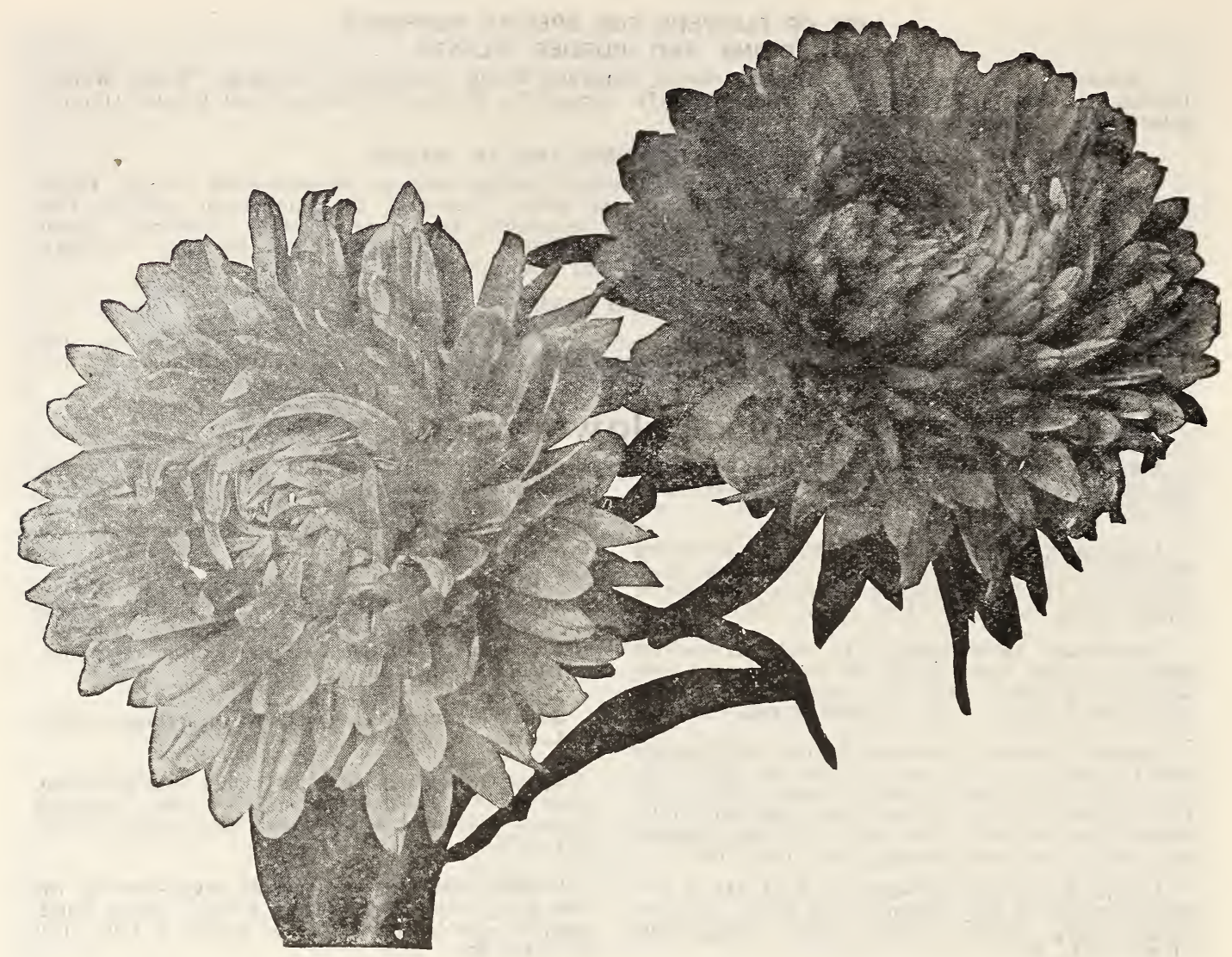

\section{Asters}

\section{(Half-Hardy Annual)}

Asters are today one of the most popular summer and autumn flowers, as they appear in their fullest beauty when the ordinary flowers are beginning to look rusty. Indispensable ior the flower garden, fine as a show plant for fairs and exhibitions, and charming pot plants. Very profuse bloomers, with exceedingly beautiful flowers of the most exquisite colors and almost perfect form.

Asters are classified accorảing to their height, as tall, half dwarf and dwarf. The tall varieties are fine for the center of large beds and for cutting; the dwarfs are particularly fine for borders or masses of one color, as they are compact and bloom very profusely; the semi-dwarfs are good for all purposes and extra fine for pot culture.

Plants from seeds sown in the open ground in May will bloom in September and October; if started in the hotbed, post or boxes in the house, in March or April, flowers can be had in July and August. In hot, dry weather mulch liberally with old manure or coarse litter, and do not let them suffer for water.

Snowball-The best dwarf white aster. The beautiful shape of the snow-white flowers and the free flowering habit of the piants are unequalled in any other dwarf aster. Pkt., IOc.

Daybreak-A beautiful easy aster, commencing to bloom in August; the flowers are ball-shaped, very double and of a lovely shell-pink color; excellent for cutting; height, 18 inches. Pkt., 10c.

Comet-A good bedding variety, with large blossoms, the petals of which are long, narrow, and curled backward. Mixed colors, pkt., 10c.
New Giant Comet-Flowers are extra large, with long, wavy curled petals, simiiar to Japanese Chrys. anthemum. Plants attain a height of $21 / 2$ feet; of branching habit and long stemss. Mixed, pkt., 10c.

Queen of the Market-The best early aster, usually in full bloom two weeks hefore most other sorts begin to blossom. Of graceful spreading habit. The plants are about one foot high, bearing from ten to fifteen finely formed flowers on long and graceful stems. The colors include white, pink, deep rose, light blue, dark blue, violet and crimson. Pkt., 10c:

Trauffaut's Peony-Flowered-A valuable and standard variety. The most perfect Peony type known. Tall growing, and bearing an enormous quantity of extra large double flowers beautifully incurved and of every shade, from pure white to glowing crimson. Mixture of all colors, pkt., IOc.

Vick's Branching-A class of very strong growing asters not coming into bloom until very late, but producing flowers so large, double, perfect in form and borne on such long stems that florists sometimes sell them for chrysanthemums. Mixed, pkt., 10c.

Customers' Selection of Asters-Any three 10-cent packages for 25c; any six 10-cent packages for $45 \mathrm{c}$.

\section{Mixed Asters}

A bed of mixed asters, all kinds, colors and varieties, is certainly attractive. We offer in mixtures of both dwarf and tall-growing sorts separate.

Mixed Tall-Growing Asters-All sorts and colors; will make an interesting and attractive bed. Large pkt., 10c.

Mixed Dwarf Asters-All the low-growing sorts.

Pkt., 10c. One packet of each for 150. 
Bells Perennls fl. pl. (Double Dalsy) (H. P.) Flowering early in the spring; very double. Fine for borders, requiring partial enade in hot weather. Finest Mixed. Extra 4 in. Pkt., 10c.

Bignonia (Trumpet Vine)-Magnificent, hardy perennial climber, with brillient scarlet or yellow flowers; a most ornamental and effective covering for walls, houses, etc., $30 \mathrm{ft}$. Fkt., 10c.

Brachycome (Swan River Daisy)-A hardy annual, growing from 6 to 10 inches high and producing an abundance of pretty blue and white flowers. Pkt., 5c.

Browallia (H. A.) - Excellınt free-flowering verbena-like flowers. Will flows all sumner in the open, also making excellent hruse plants for winter use. 18 in. Finest Mixed, pikt., $5 \mathrm{c}$.

Cacalia (Tassel Flower) -A beautiful and profuse flowering plant, with tassel-shaped orange and scarlet flowers; fine for mixed borders; hardy annual. Pkt., 5c.

Calendula (Pot Marigold) (H. A.)-Large double flowers, blooming all summer, closing somewhat at night and opening slightly on cloudy days; flowers borne on long, stiff stems. 2 ft. Double, Finest Mlxed, pkt., 5 c.

California Poppy-See Eschscholtzia.

Calliopsis (or Coreopsis)-une of the most effective of our hardy annuals; very showy in open garden and excellent for cutting; flowers borne on individual stems 18 inches in length. Worthy of a place in every garden. $2 \mathrm{ft}$. Finest Mixed, pkt., $5 \mathrm{c}$.

Antlrrhinum (Snapdragon) (H. A).-Orie of the finest flowers for cutting in existence, bearing long spikes of gorgeously colored flowers. It is also grown extensively under glass in the winter. Seed sown in the house or hotbed during February or March will flower in July and continue until frost. They succeed best in rather light soil, in a sunny position and although perennials, succeed well when treated as annuals. The tall varieties grow about 2 ft., the dwarf ones about 12 iriches high.

Tom Thumb Mixed-Large variety of colors; best for bedding. Pkt., $5 \mathrm{c}$.

Tall Mixed-Extra fine selection; best for cutting. Pkt., 5c.

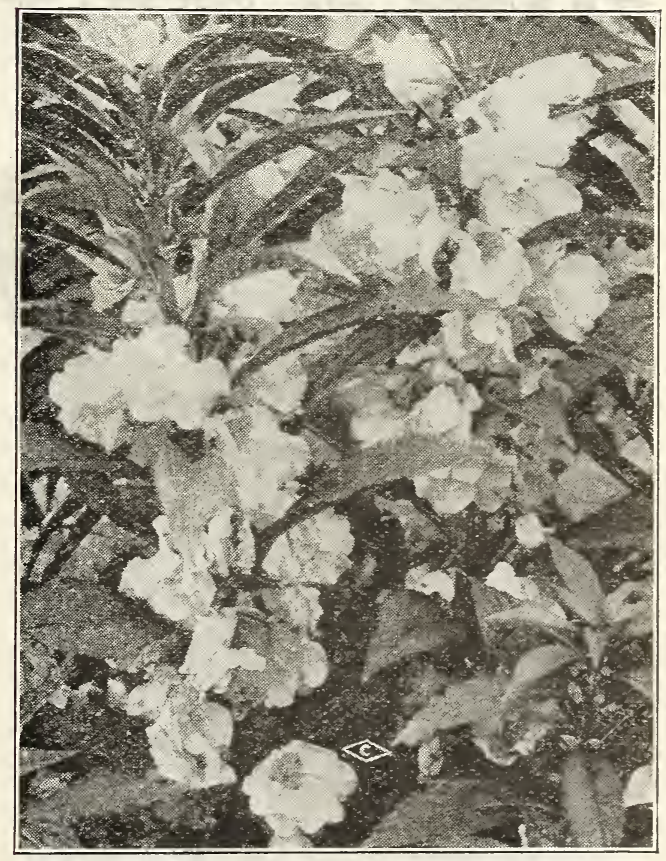

Balsam

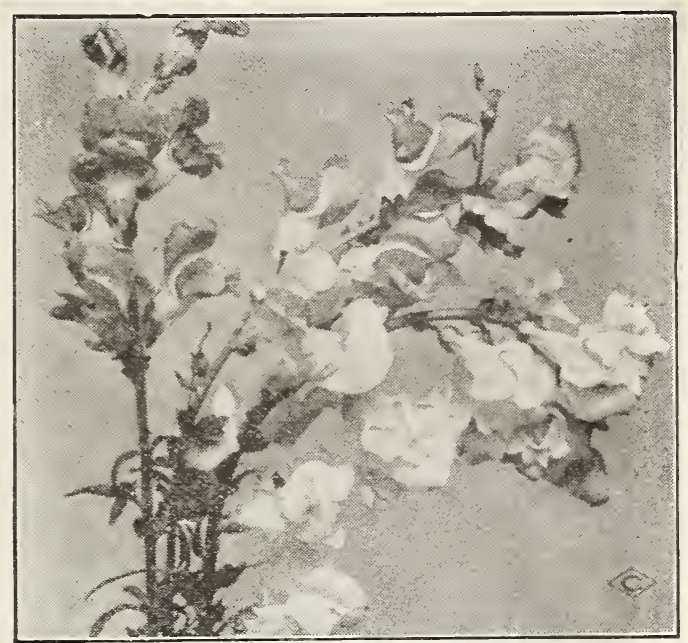

Antirrhinum

Aquilegia-See Columbine.

Armeria. (Thrift, or Sea Pink) (H. P.)-Pretty little plants for borders or edgings, growing in tufts. Pkt., 5c.

Asperula odorata (Sweet Woodruff) (H. P.)Free-flowering plants which thrive well in shaded places. Flowers white, sweat-scented. $1 \mathrm{ft}$. Pkt., 5c.

Amaranthus (H. A.)-Brilliant foliage annuals, growing from 3 to $5 \mathrm{ft}$. high. Very useful in borders of tall plants or for the centers of large beds. Give plants plenty of rcom.

Caudatus. Love Lies Bleeding-Brilliant blood red of drooping habit, $3 \mathrm{ft}$. Pkt., $5 \mathrm{c}$.

Tricolor, Joseph's Coat-Leaves red, yellow and green. Pkt., 5c.

Ammobium Alatum (H. A.)-Valuable white everlasting; when fully expanded the flower has a yellow center. When sown early and treated as a hardy annual, the plants bloom freely the same year. Height, $2 \mathrm{ft}$. Pkt., 5c.

Ampelopsis (H. P.) Quinquefolia (VIrginia Creepor or Woodbine) - Foliage turns scarlet in fall. 50 ft. Pkt., $5 \mathrm{c}$.

Balloon Vine (Live in a Puff) - A rapid growing, annual climber, attaining a height of 10 to 16 feet; bears small, white flowers, followed by inflated seed pods, hence the name. Pkt., 5c.

Balsam (Lady's Slipper, Touch-Me-Not)-An old favorite, producing gorgeous masses of beautiful, brilliant colored flowers in the greatest profusion, double as roses and in every shade of color. Sow in house in April, transplant in open ground in May. Perfection White Queen-Finest double, pure white. Pkt., 5c.

Double Camelia-Flowered-Finest mixed. Pkt., 5c.

Choicest Double Mixed Colors-Pkt., 5c.

Bean. Scarlet Runner-A tall or climbing bean with beautiful red and white blossoms. Pkt.o 50.

Campanula Media (Canterbury Bells) (H. B.)Plants grow in pyramidal form, bearing in profusion large, bell-shaped flo:vers. Very showy in mixed borders or among shrubbery. Colors, white, and various shades of violet, rose, lilac and blue. Height, 2 to 4 feet. One of the wild forms of Campanula is the "Blue Bells of Scotland." Seeds sown in February will flower first season; sown in July will flower following season. English Prize Mixture. $3 \mathrm{ft}$. Pkt., $5 \mathrm{c}$.

Canary Bird Flower (Tropoeolum canariense) - A beautiful climber with small, curiously shaped canary colored blossoms. Will bloom freely from July until killed by frost. Tender annual; height about 20 feet. Pkt., $5 \mathrm{c}$. 


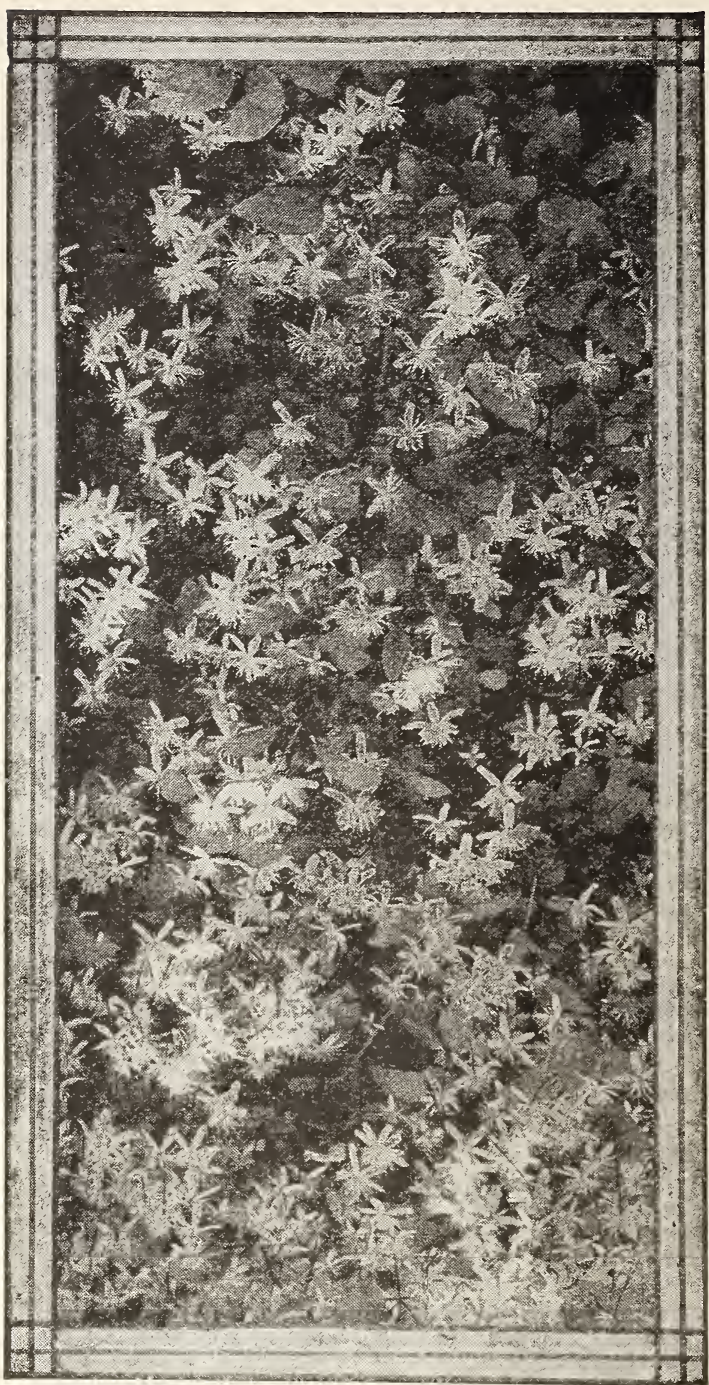

Clematis

Candytuft (H. A.) - Very showy for borders; flowers form in spikes; plants of branching habit. One of the best cut flowers for briquets.

Giant Empress-White; extra large. Fine for forcing. $2 \mathrm{ft}$. Pkt., 10c.

Finest Mixed-1 ft. Pkt., 5c.

CandidissIma-Ornamental plant of great beauty. Silvery white, deeply cut foliage. Pkt., 10c.

Chrysanthemum-Annual varieties. These are showy and effective garden varieties extensively grown for cut flowers. The foliage is ornamental and finely cut. The single varieties grow 12 to 18 inches high and produce on long stems large flowers resembling the Daisy, but of many bright colorings in distinct bands or rings. Finest Mixed, SIngle, pkt., 5c. Finest Mixed, Double, Pkt., 5c.

Clematis-A popular hardy perennial climber. An old favorite and justly so, for there are few garden climbers that give more satisfuction. Pkt., 100.

\section{Carnations}

Oarnations are general favorites on account of their bright colored, deliciously fragrant flowers. The Marguerites and Chabauds are the best for summer blooming; the strains which we offer nere are the best and largest flowering and also the very earliest and can be had in bloom four months from sowing.

Perpetual Early-Flowering, double Chabaud-A very fine, early and large-flowering strain, likely to produce flowers fully equal to the best greenhouse sorts; it contains a great variety of colors and shades, very fine for pot plants. Mixed colors. Pkt., 15c.

Carnation Marguerito-This new race of Carnations, unlike all others, bloom in about three months from the time of sowing the seed and continue to flower until checked by frost. They embrace a fine range of brilliant colors, are very fine flowering. Best Mlxed, pkt., .5c.

Castor OII Bean (Ricinus)-A half-hardy annual, growing from 6 to 15 feet high and bearing large, green, deep purple, and brown leaves and bright orange and scarlet flowers. The seed pods resemble a prickly fruit. Of the easiest culture. Pkt., 5c; 0z., 10c.

Catch-Fly (SIlene)-An attractive and generous bloomer with brilliant dense heads of flowers. An excellent plant for bordering walks and circular beds. Hardy annual; height, 18 inches. Pkt., $5 \mathrm{c}$.

Colosia Cristata, or Cockscomb-A half-hardy

annual, growing 6 to 8 inches high, bearing a wide, wavy blossom that resembles a cock's comb. In brilliant colors and fine for massing or border work.

Dwarf Mixed-Several shades of red and yellow, mixed. Pkt., 5c.

Celosla Plumosis, or Feathered Cockscomb-This species grows two or three feet high, and bears long, feathery plumes in brilliant colors. Mixed. Pkt., 50.

Magniflcent (Thompson's)-A new variety, superior to the older sorts, bearing grand spikes; flowers in mid-summer. Mixed. Colors have a wide range. Pkt., $10 \mathrm{c}$.

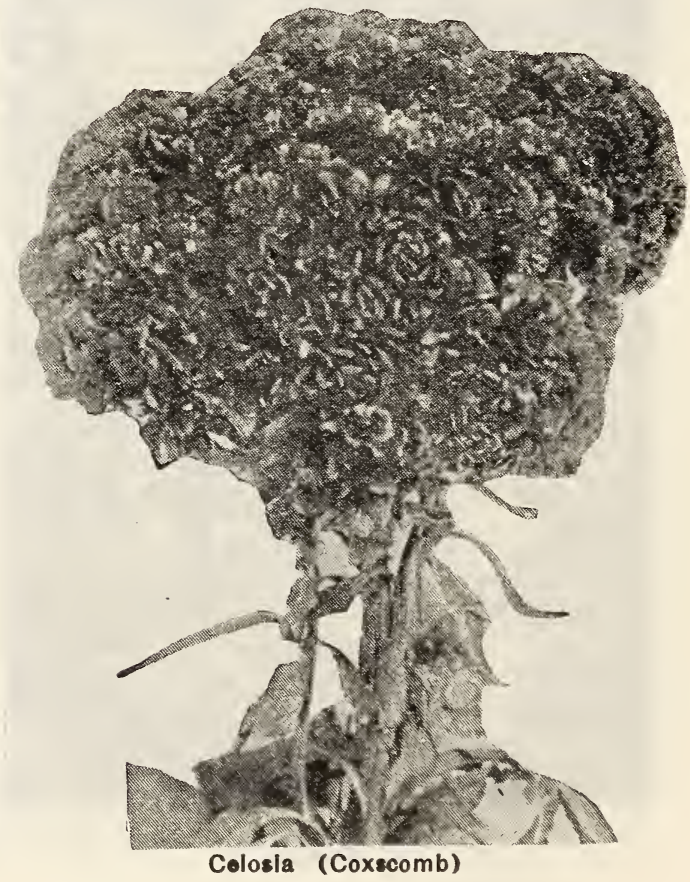


The following Centaureas are perfectly hardy annuals, of easy culture, and are general favorites both for the garden and for cut-flowers. Seed should be sown early where plants are desired to bloom. Plants should stand one fost or more apart each way.

Cyanus (Bachelor's Button, Corn Flower)-This is the flower seen in such great abundance in the fields of Europe. If seed is sown as soon as the ground is fit in the spring and the flowers picked so as to prevent the plant exhausting itself by seeding it will furnish a profusion of bright blue, purple, white or pink flowers from July until late in the autumn. One to two feet high. Mlxed oz., $20 c$; pkt., $5 c$.

Imperlalls (Royal Sweot Sultan)-A strain of Giant-flowering Sweet Sultan; the finest of all for cut flowers. Blooms continanusly from summer till autumn. The flowers are of various colors, from glistening white, through shades of pink, lilac, crimson, and violet, to purple. Very fragrant. Plant vigorous, nearly four feet high, and covered with enormous flowers on very long stems. Mixed colors. Pkt., 10c.

Marguerlto-A sweet scented, white Centara, about as large as a medium sized carnation. The flowers are beautifully lacinated and produced on long stems and their lasting quality after being cut is remarkable. Pkt., 10c.

Clarkla-A hardy annual, of easy culture, growing about 18 inches high :ind bearing bright rose, white, or purple flowers in great profusion. Native of California. Pkt., 5c.

Columblne (Aquilegla) (P) - Hardy plants, growing about 2 ft. high, blooming in May and June. Beautiful perennials, with ine foliage, abundance of long-stemmed, graceful flowers; should be more generally cultivated.

Aqullegla Coerulea (True Rocky Mountaln Columblno) - Colorado's emblematic fiower. Needs to be seen to be appreciated. The nower petals lay open more flat than the common Columbine. Color is a light blue, in very high altitudes nearly white. Pkt., 10c.

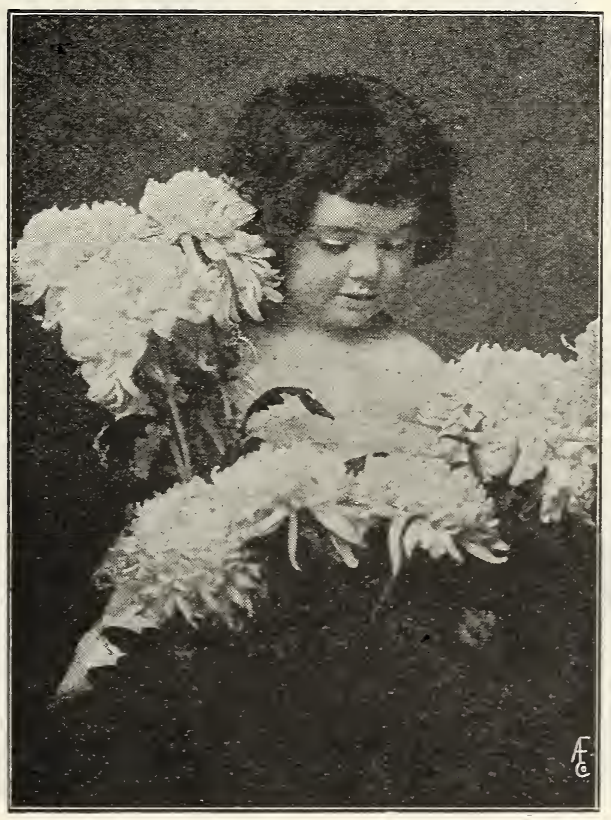

Chrysanthemums

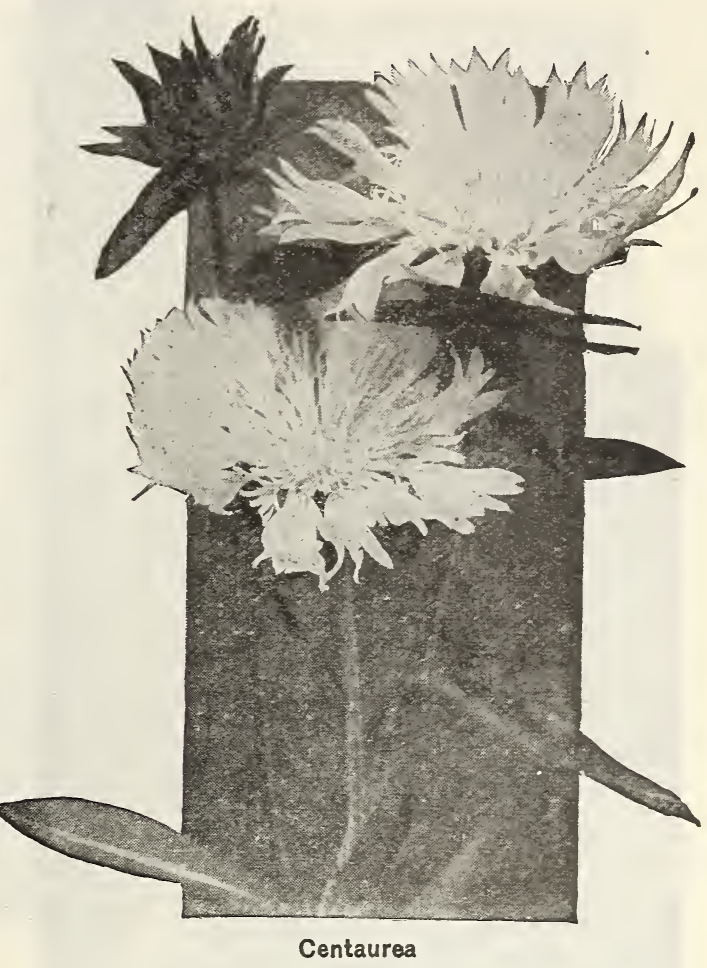

California Hybrlda-One of the hardiest and most free blooming of all columbines, having orange red and yellow flowers. Oz., \$2.50; Pkt., 10c.

Mixed Double-Best and finest colors. Oz., 30c; Pkt., 5c.

Cobaea Scandens-Cathedral Bolls - $30 \mathrm{ft}$ : One of the handsomest and rapid growing climbers. The flowers are bell-shaped and of a purplish-lilac when full grown. It is a very prolific bloomer. Mixed white and blue, pkt., $10 \mathrm{c}$.

Coleus (A)-Gorgeous colored variegated foliage: indispensable for ornamental bedding, fine for pot culture. Fine Varieties. Mixed, pkt., 15c.

Cosmos-This beautiful annual is one of the most showy and useful of our garden plants. Plants grow from 4 to 6 feet in height, and are very bushy and compact. Flowers borne on long delicate stems and are similar to single Dahlias. Foliagc very finely cut. Excellent for cutting.

Klondyko-A gorgeous orange-yellow variety witl very handsome foliage more coarsely lacinated than other sorts. Pkt., 10c.

Lady Lenox-Beautiful shell pink. Flowers are from 4 to 6 inches in diameter; stems from 1 to 3 feet long; plants strong and vigorous growers. Pkt., 10c.

Early Flowering, Finest Mixed-Includes white bright red and rose colored flowers. Seed if sown in March and April will flower during July. Pkt., 5c.

Glants of Californla-Flowers double the size of the old varieties. Pkt., 10c.

Cypress VIne (Ipomoea Quamocllt) - A tender, climbing annual, with soft fern-like foliage and small starlike flowers in red and pink, or white. Mixture of several colors, pkt., $5 \mathrm{c}$. 


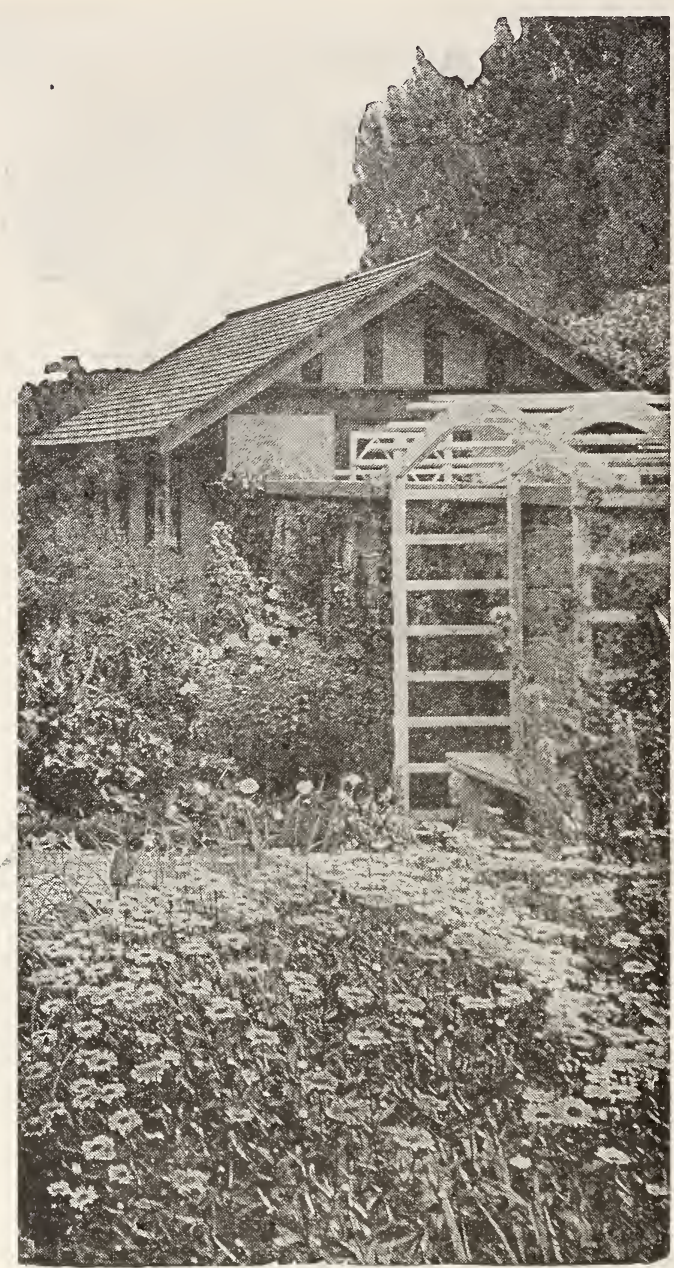

Shasta Daisy Planting

Daisy-Charming little plants for edging and borders. The flowers are quilled and flat-petaled, white, pink, red and variegated. Height, six inches. Tender perennial.

Shasta Daisy-This is one of the creations of Mr. Luther Burbank. It is verfectly hardy, grows anywhere and blooms more aliundantly each season. The flowers are very large. Alaska, pure white; California, pale yellow; Westralia, cream yellow; each, pkt., 10c.

Daisy, Snowball-Large flowered, pure white and extremely double, with very long stems, making them valuable for cuting. Pkt., 10c.

Daisy, "Longfellow"-Flowers of unusual size, a dark rose color. Pkt., 10c.

Daisy, Double-See Bellis Perennis.

Datura (Trumpet Flower, or Horn of Plenty) - A tender annual, growing three feet high. Flowers large and trumpet-shaped. Pkt., 5c.

Delphinium-See Larkspur.

Dianthus, or Pinks-Hardy annuals, about one foot high, and bearing beautifully colored, single and double blossoms in profusion all summer.

Cheenensis-China or Indian Pink. Finest double mixed. Pkt., $5 c$.

Heddewigii-Double Japan Pink. Seed sared from the best double flowers only. Fine collection of colors. Pkt., 5c.
Imperialis-Double Imperial Pink. Fine mixture of colors. Pkt., 5c.

Laciniatus (Single Fringed Pinks) - A very fine fringed variety; many rich colors. Pkt., 5c; 1/4 oz., 25c.

Eschscholtzia (California Poppy) (A)-1 ft. The state flower of California. A bright free-flowering plant of low spreading growth with finely cut silvery foliage. The poppy-like flowers in pure shades of yellow, orange and crimson are produced from early spring until frost. Sow the seed where the plants are to remain. Californica. The original yellow. Finest Mixture. Pkt., 5c.

Feverfew (Double)-Handsome large double white flowers, excellent for bedding; also for house culture; blooms abundantly all sedson; 12 inches high. Pkt., 5c.

Forget-Me-Not (Myosotis)-A hardy perennial growing about 6 to 10 inches high. Small star-like flowers are borne in clusters on long stems. Of easy culture and will bloom the first year if seed is sown early. Finest Mixed. Pkt., 10c.

Four o'Clock (Mirabilis)-The Marvel of Peru, or Four o'Clock, is one of the most brilliant and showy of annuals. Planted in beds or masses, their very compact growth, rich glossy leaves, together with their profusion and diversity of bloom, present a gorgeous sight in afternoon. Mixture of all colors. Pkt., 5c; 0z., 20c.

Foxglove (Digitalis) - One of the finest of perennials, bearing long spikes of gloxinia-like flowers of tubular shape. Plants will grow in partial shade and in almost any good garden soil; attains a height of $4 \mathrm{ft}$. Mixed. All the choice colors. Pkt., 5c.

Gaillardia (Blanket Flower)-Very showy annuals used abundantly for borders and bedding and fine for cut flowers. Seed should be started early and will flower continually until frost. Single and Double Mixed, pkt., 5c.

Globe Amaranth (Gomphrera) (H. A.)-Globeshaped, everlasting flowers. When in full bloom should be cut and hung up to dry; will hold their color all Winter. Finest Mixed. 2 ft. Pkt., 50 .

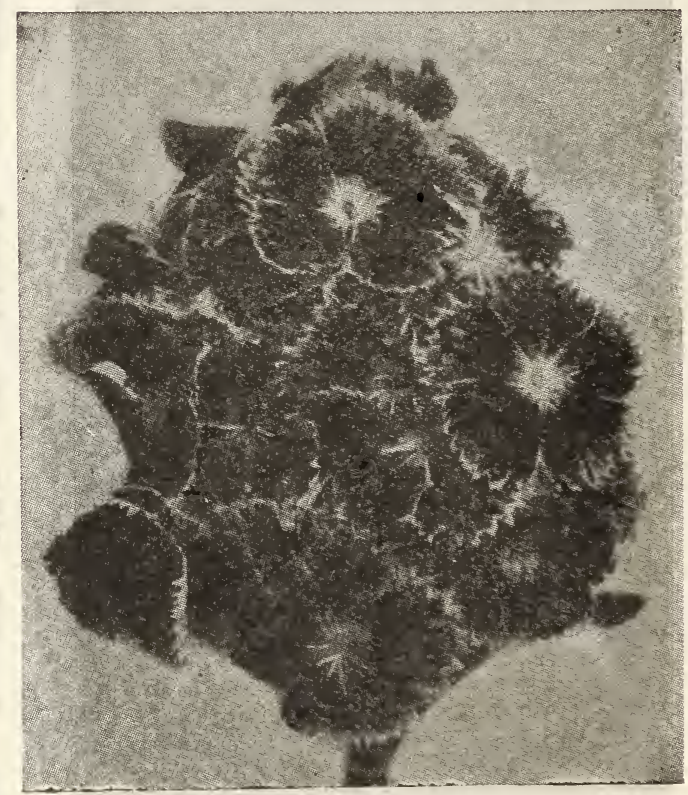

Dianthus (Pinks) 
Godetla (Satin Flówer) (H. A.)-Rapid growing annual shrub, producing large, mallow-like flowers; very ornamental in mixed beds. Plants require plenty of room and thrive vetter in a poor soil. 18 inch. Mixed, pkt., $5 \mathrm{c}$.

Golden Rod-Considered a reed on our Western prairies, it has been adopted by New York as state flower. Admired by all; easily grown from seed. Pkt., 5c.

Gypsophila-Sometimes called "Baby's Breath" or "Angel's Breath." Delicate, free-flowering plant covered with small, star-shaped flowers. Well adapted for hanging baskets or edgings, and valuable for making bouquets. White and rose-pink flowers. Hardy annual; one foot. Mixed, pkt., $5 \mathrm{c}$.

Gourds-See page 8.

Heliotrope-ls a universal favorite on account of its delightful fragrance and long duration of bloom, flowering equally well as bedding plants in summer or as pot plants in the house in the winter. It is not generally known that Heliotrope may be raised from seed as easily as the Verbena. Mixed, pkt., 10c.

Helianthus-See Sun Flower.

Helichrysum (Straw Flower)-A hardy annual of the easiest culture; one of our best "Everlasting" flowers, the dried double blooms being very handsome in winter bouquets. 2 feet. Mixed, pkt., 5 c.

Hibiscus ( $P$ ) (Mallow)-Vigorous-growing plants, producing large, handsome ilowers, often six inches across. Very desirable for mixed beds or borders. Mlxed, pkt., 5c.

Hollyhock-Entirely different and more beautiful than the plant of twenty years ago, being much more compact in growth, the flowers larger, more richly colored and of better form. For a background to a flower garden uothing is better. All double varieties are hardy perennials; five feet high.

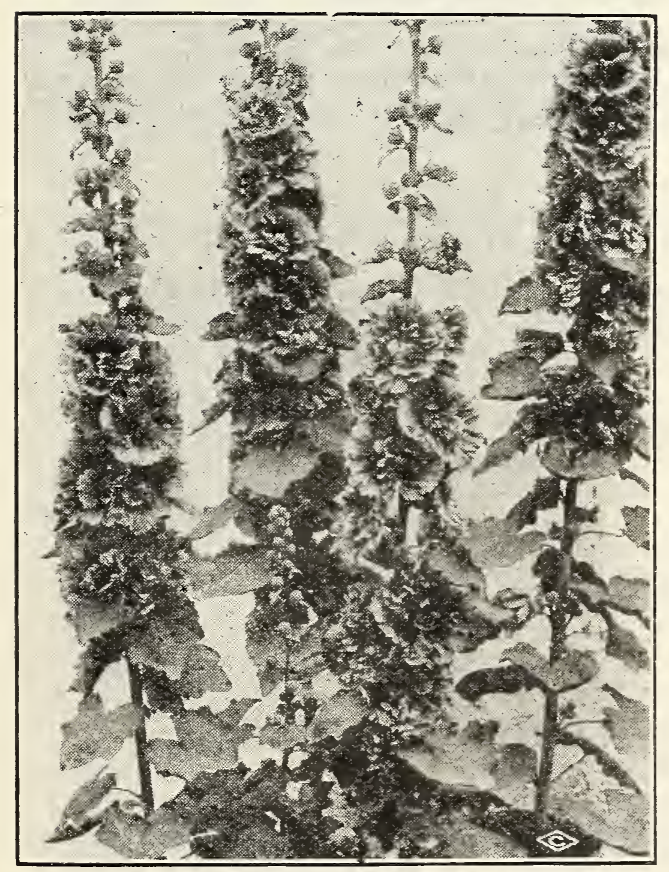

Hollyhocks

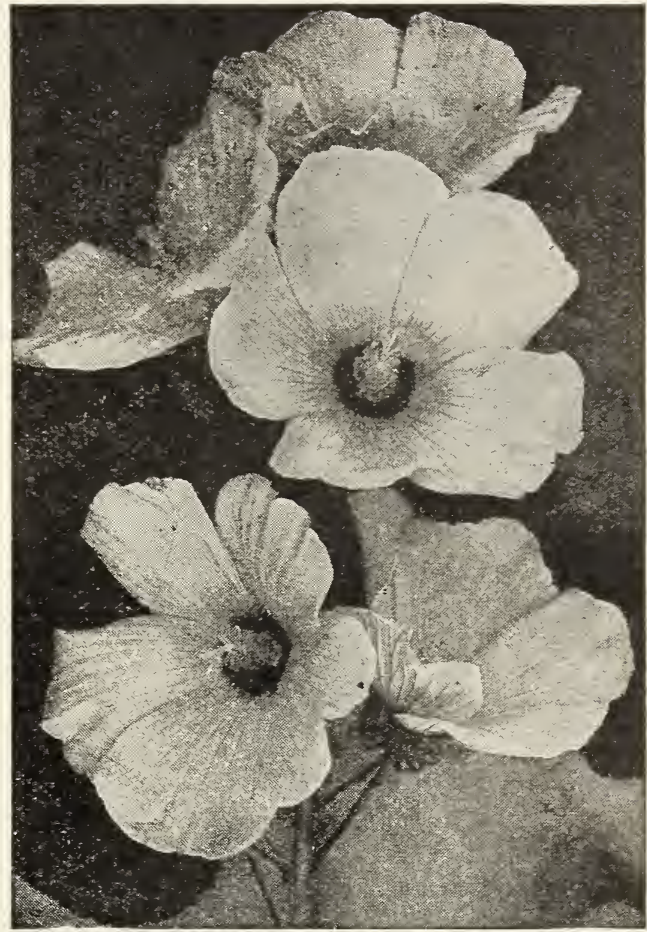

Hibiscus

Early Flowering-Blooms readily the first year from seed affording a wide rainge of colors in large single or semi-double flowers. Pkt., 10c.

Allegheny Mammoth Fringed-An entirely distinct variety. Flowers are single, dcuble and semi-double, of fine form and rich colors. Splendid for the border or for the hardy garden. Pkt., 10c.

Chater's Prize Double Mixed-Magnificent double flowers three to four inches across, and all of the brightest colors. Pkt., 10c.

Humulus (Japanese Hop) H. A.)-Climber of rapid growth. Fine for covering verandas and trellises, attaining a height of $12 \mathrm{ft}$. Pkt., 5c.

Hyacinth Bean-A fine climber with clusters of purple or white flowers followed by ornamental seed pods. Tender annual; growing from ten to twenty feet high. Pkt., 5c.

Job's Tears (Coix Lachryma)-An ornamental grass, imported from East India, with broad cornlike leaves. A vigorous grower and used extensively in winter bouquets. Strings of handsome beads are formed from the seeds of this plant. Hardy annual; height, 3 feet. Pkt., 5 c.

Kochia Tricophylla (Also called Mexican Burning Bush or Summer Cypress) - A splendid ornamental annual plant, forming dense cral bushes 2 to $2 \frac{1}{2}$ feet high, of small, feathery, light green foliage. As summer advances this changes to a carmine hue and finally to 2 firey red. A very attractive plant at all times. Pkt., 5c.

Lantana-Tender perennial, stowing from 2 to 3 feet high, bearing Verbena-like clusters of flowers, in orange, white, rose and other colors, excellent for bedding. Choice Mixed, pkt., 5c. 


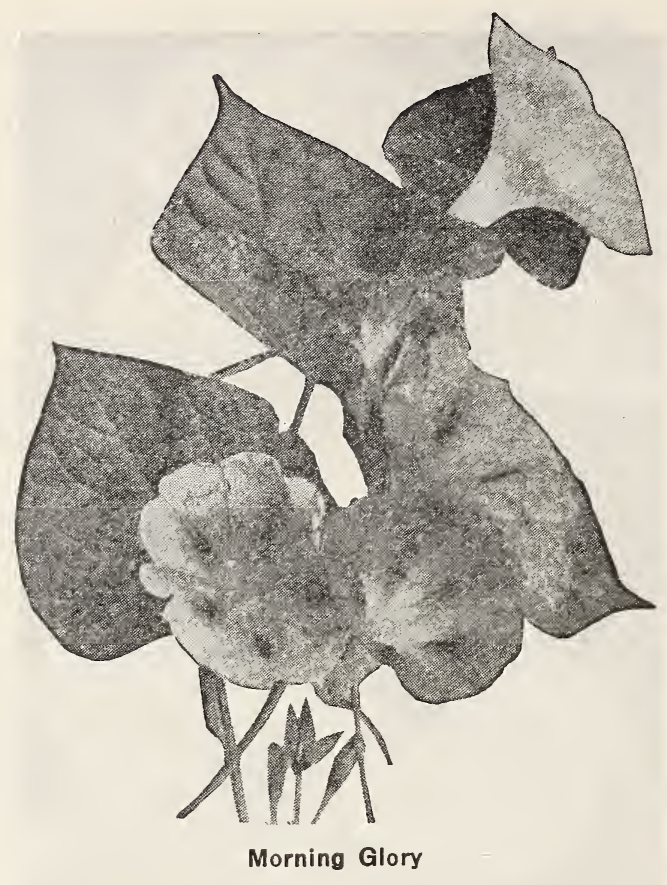

Larkspur (Deiphinium)-The Larkspur is one of the handsomest and most useful of plants and for large gardens is invaluable. There are two classes of the Larkspur which are quite distinct-the annual and the perennial.

Annual Larkspur-A fine variety of colorsshades of blue, red, and others striped and mottled. Double Dwarf Rocket, Finest Mixed; Tall Rooket, Double Mixed; pkt., $5 \mathrm{c}$.

Perennial Larkspurs are most showy and useful in permanent plantings, as they produce splendid spikes of flowers all summer. Perfectly hardy. Choice Mixed. Best Varieties. Pkt., 5c.

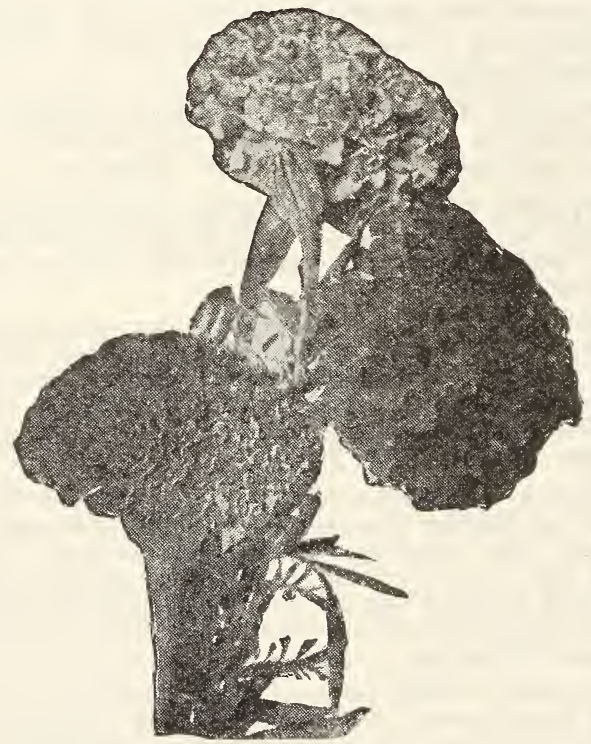

Marlgold
Lavender-Chiefly cultivated for the delicious and lasting fragrance of its flowers; succeds in any common garden soil. Perennial. Pkt., 5c.

Linum, or Scarlet Flax-A hardy annual about one and one-half feet high. Of slender and graceful appearance, with smooth stems and bright-red flowers, which are borne in great profusion. Pkt., $5 \mathrm{c}$.

Lobolla-This popular and beautiful flowering plant is most desirable for pot culture, edgings, hanging-baskets, etc., blooming profusely from June to November. Plants grow about 6 inches high. They are treated as annuals and are of the easiest culture.

Crystal Palace Compacta-Best dark blue sort for edgings and carpet bedding. Pkt., 10c.

Gracilis-Fine for hanging baskets, vases and window boxes. Light blue. A trailing variety. Pkt., 5c.

Marigolds-Old-fashioned flowers, rich and showy, blooming continually all Summer; excellent for bouquets and a beautiful garden plant. Tall African varieties best for garden and cutting, while French varieties are fine for edging. Annual Mammoth African, Finest Mixed Double, 3 ft., pkt., 5c, French Dwarf Double, Finest Mixed, 2 ft., pkt, 5c.

Moon Flower (Ipomca grandiflora alba)-One of the most vigorous of all the summer climbers and will grow thirty to forty feet in a single season and be covered with its large, white flowers every evening and cloudy day. Tender annual. Pkt.o IOc.

Morning Glory (Convolvulus)-A climbing annual, growing about 10 feet high in one season, flowers are well known and exist in a great variety of colors.

Major-Tall climbing. Mixed, pkt., 5c; oz., 15c.

Finest Mixed Japanese-Very choice strain; flow. ers large, and in greatest variety of colors and shades. Pkt., 5c; $1 / 2$ 0z., 10c; 0z., 15c.

Dwarf, or Bush Varieties (Convolvulus Minor) Plants grow ten to twelve inches high, and are hardy annuals. Useful for beds, edges or hanging baskets. Mixed, pkt., $5 \mathrm{c}$.

MImulus (Monkey Flower).-Magnificent, dwarf, half-hardy perennials, which flowers profusely, thriv. ing best in moist situations.

Tigrinus (Monkey Flower) - Fine mixed spotted and blotched flowers. Pkt., 5c.

Moschatus (Musk-Plant)-Grown for its musky odor; fine for hanging baskets, etc.; small yellow flowers. Pkt., $5 \mathrm{c}$.

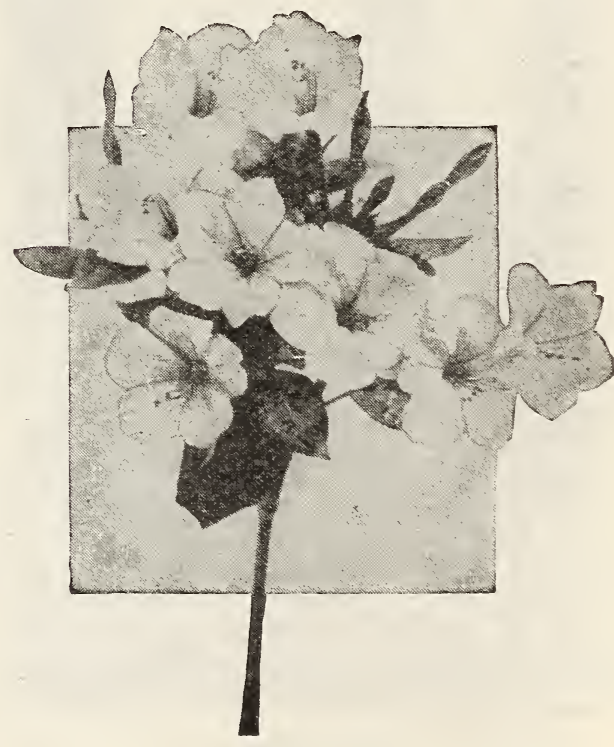


Mignonette-A general favorite on account of its delightful fragrance. Blooms throughout the season. Sow from middle of April to middle of June. Most fragrant on poor soil. Hardy annual; height one foot.

Improved Machet-A highly developed strain; splendid, large, red flower spikes. One of the very best for pot culture. Pkt., 10c.

Parson's White-Flowers almost pure white, borne on spikes six inches to a foot in length. Pkt., 5c.

Swoet Mignonette (Reseda Odorata)-The oldfashioned, deliciously sweet scented variety. Pkt., $5 c$.

Finest Mixed Varieties-An elegant mixture of many other choice sorts. Pkt., 5c.

Morning Bride-See Scabiusa

Myosotis-See For-get-me-not.

\section{Nasturtiums}

For freedom of bloom, ease of culture and handsome effect, few flowers equal the Nasturtium. They are of quick growth, thrive in the poorest soil and give the greatest abundance cf lovely, sweet scented flowers. Splendid when used as cut flowers.

\section{TALL OR CLIMBING VARIETIES}

Chameleon Nasturtiums-Almost every shade of color and marking known to uasturtiums; continually changing from day to day. A very atractive strain. Pkt., 5c; oz., 15c; 2 oz., 25c; 1/4 lb., 40c.

Lobbianum-(Lobb's climbing Nasturtiums). Differ from the ordinary climbing sorts in having smaller, neater and more projuse flowers. The vines attain a length of six or eight feet.

Lobb's Mixed-From named sorts. Pkt., 5c; 02. $15 \mathrm{c} ; 2$ 0z., $25 \mathrm{c} ; 1 / 4$ ib., $40 \mathrm{c}$.

\section{MADAM GUNTER'S HYBRIDS}

A grand strain of tall growth, containing many colors not found in any other mixture.

Many coiors mixed, pkt., 5c; $1 / 2$ 0z., 10c; 0z., 15c; 2 oz., 25c.

Tail Varieties Mixed-All the above varieties, besides many others, in a splenjid mixture. Pkt., $5 \mathrm{c}$; oz., 10c; $1 / 4$ lb., 25c; ib., 70c.

\section{DWARF OR TOM THUMB}

Dwarf Nasturtiums are very desirable for borders along walks, paths, etc. They are in constant bloom. Grow about a foot high.

Finest Dwarf Mixed-This includes many showy colors, having both light and dark foliage, in mixture. A very wide range of flowers in beautiful colorings. Pkt., 5c; 0z., 10c; 2 0z., 15c; 1/4 lb., 25c.

Variegated-leaved Dwarf Mixed-A splendid range of colors of these new striking variegated-leaved sorts. Pkt., 5c; 0z., 15c; 1/4 Ib., 50c.

Nicotiana (Sweet Scented Tobacco) (H. A.) Flowers borne in clusters, long, tube-shaped, opening toward evening and emitting a powerful and pleasant odor.

Affinis-White, and very fragrant. Pkt., 5c.

Nigeila (Love-in-a-Mist, or Devil-in-the-Bush) (H. A.) - Plants bear very showy isowers, with the foliage finely cut; form very curious; interesting plants. Height, one foot. Double, mixed colors. Pkt., 5c.

Enothera (Evening Primrose)-An attractive hardy perennial border plant of dwarf compact habit, producing an abundance of bright showy flowers, in white, pale yellow, rose, etc. Of very easy culture, preferring a light dry soil.

Fine Mixed-Height 6 inches. Pkt., 5c.
Ornamental Grasses-Very useful for winter bouquets to work in with everlasting flowers. Select strains. Pkt., $5 \mathrm{c}$.

Oxalis-A half hardy perennial bulbous plant growing about nine inches high and suitable for greenhouse, rock-work, or edgings. Flowers bright colored and showy. Mixed. Pkt., 10c.

Passion Flower (Coerulea) - A beautiful perenial half-hardy climber with blue and white flowers. Pkt., 10c.

\section{Bedding Petunias}

Striped and Blotched-A most beautiful strain of Petunias for bedding and massing. Our mixture contains an endless variety of colors. Pkt., $5 \mathrm{c}$.

Finest Mixed-A choice mixture of colors and shades; will make a fine display in your garden. Pkt., 5c.

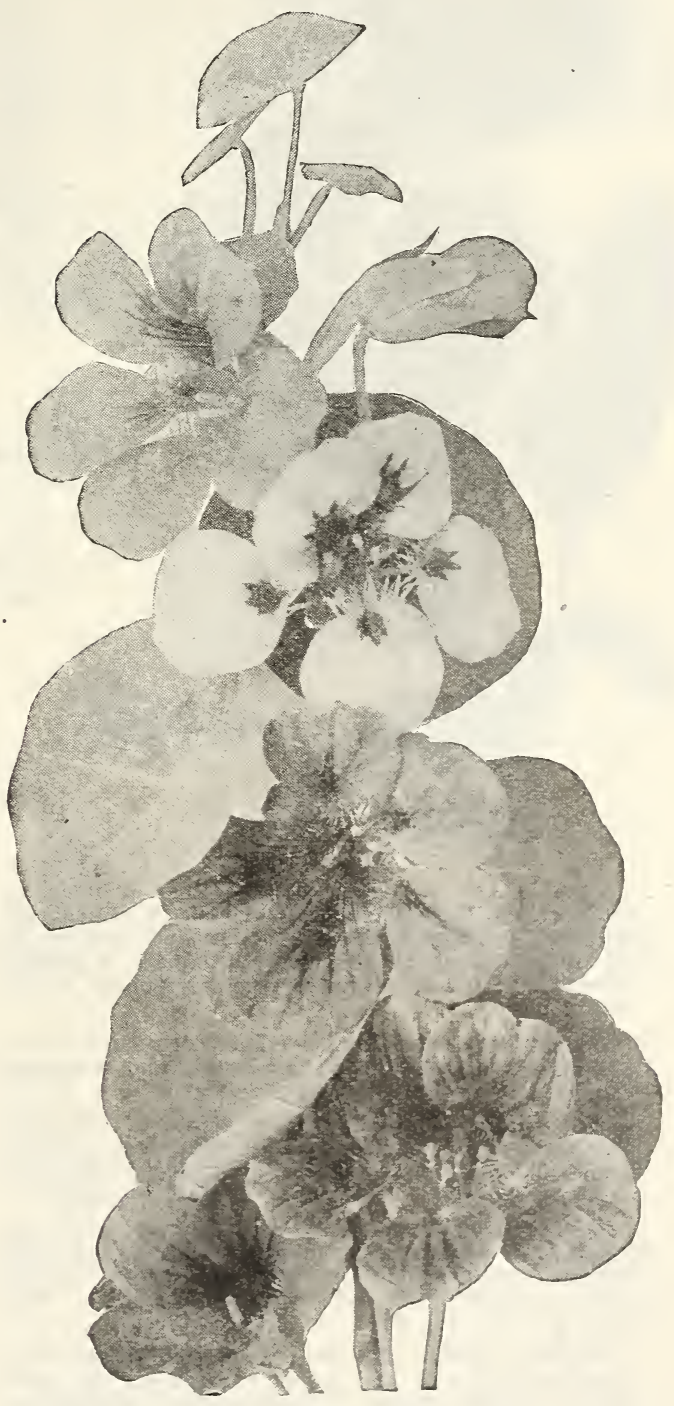

Dwart Nasturtiums 


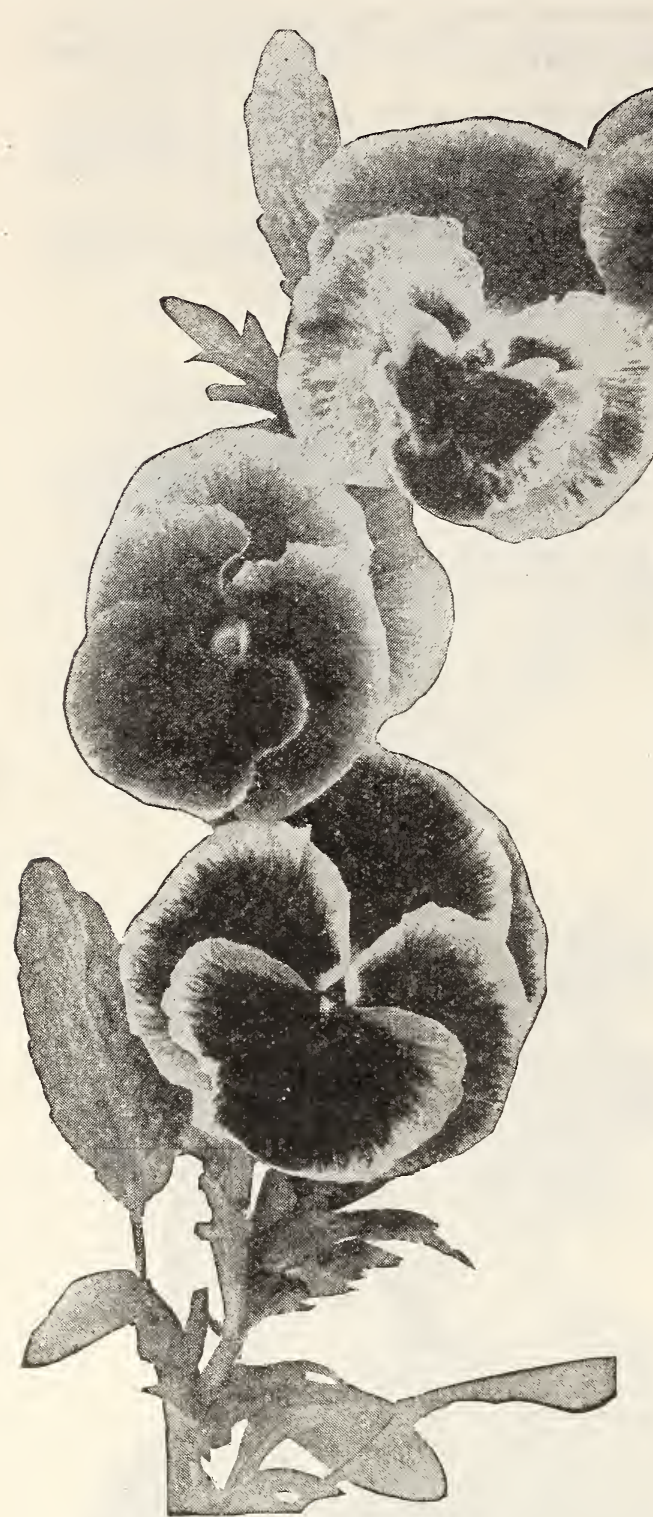

Potunla (H. A.)-One of our most popular annuals of the easiest culture, thriving in almost any soil and frequently seeding itself and coming up the following year. No other produces a greater diversity of color, retaining their freshness for so long a period.

Large-Flowering Petunias-The blooms are enormous in size and of the richest colors and markings. Varieties listed below are unsurpassed.

Grandiflora Single Mixed-A strain of incomparable beauty and luxuriance. Fiowers most varied in colors and markings; beautifuily ruffled, fringed and of enormous size. Pkt., 15c;2 pkts. for 25c.

Giants of California-These Petunias are of great beauty and luxuriance, including fringed and deepthroated sorts in endless variety of colors, veinings throated sizeners of enormous size. Pkt., $15 c ; 2$ pkts., for 25 c.

Ruffled Giants-The flowers of this strain are of extraordinary size and great substance; the edges of the blooms ruffled. Contains the greatest variety of rare colors and combinations. Pkt., $25 \mathrm{c}$.

\section{Pansy}

Our Pansy seeds are imported direct from the leading pansy special. ists of Europe and are the best selections from the new and im. proved standard types. For early outdoor bedding seed should be sown in the early fall, in rich moist garden soil or in cold frames. Spring sowings should be made early. Pansies do best in very rich, moist soil and cool, moist atmosphere. A situation sheltered from high winds and exposed to the morning sun is most favorable and frequent sprinklings are advantageous.

Bugnots Superb Blotched-Very beautiful class, of enormous flowers with broad blotches, many having the two upper petals finely lined, showing a diversity of handsome and rare colors. Pkt., 10c. Cassiers Large Flowered Blotched-The largest flowered blotched Pansies. An incomparable strain, pro-

Masterpiece Exhibition-The finest strain of Pansies in ultivation, saved only from the largest and best shaped ers of the richest colors which are elegantly curled ulated, some so full as to appear double. Pkt., 10c.

Giant Odier or Prize Blotched, Mixed-A large flowered with round blossoms. The petals are all blotched the edge. Pkt., 100. ansies called the French strain. The top petals are larger than the 3 lower ones and are beautifully marked.

10c.

Good Mixed Pansy-This mixture embraces all of the colorings and shadings of the ordinary kinds. Pkt., $5 \mathrm{c}$; z., $\$ 1.00$.

\section{Phlox-Drummondii}

\section{(Frame Flower)}

The annual Phloxes are dazzling in effect, particularly o when sown in masses or ribbon beds of contrasting Few flowers are so easily grown from seed-and given good soil and care can be grown throughout the

Phlox Drummondii-The old- fashioned favorite variety. Our mixture contains all colors. Pkt., 5c; 1/4 0z., $15 \mathrm{c}$; oz., 50c.

Drummondil Dwarf Grandiflora-One foot high. Largest flowering, pure white, blood red, striped and variegated. Mixed. Pkt., $10 c$.

Drummondii Dwarf Mixed-A selection of brilliant colors, strongly recommended for beds, edgings, or horders. Pkts., $10 \mathrm{c}$.

Star Phlox (Star of Quedlinburg) - Of dwarf habit with very pretty star-shaped flowers. A novel and beautiful variety. Mixed color. Pkt., 10c.

Phlox, Porennial-Two to tirree feet. The great rich heads or flower masses are simply magnificent. The most admired sorts and best bloomers. Mixed. Pkt., 10c.

Pinks-See Dianthus.

Vine seeds are our specialty, which are developed and matured perfectly under irrigation.

We would like to send your friends and neigh. bors a copy of our catalog.

We prepay postage on all garden seed.

Seeds grown under irrigation produce strong plants.

Cultivate your garden thoroughly for the best results.

Gardeners who buy Beans in large quantities should write for special prices. 


\section{Poppies}

(Annual and Perennial)

Probably no class of plants enjoys greater popularity and is more widely grown than the Poppies; their wonderful range of color of their delicate, gracefully borne flowers is well known to all lovers of flowers.

The Poppies are quite hariy and the seed should be sown as early in the spring as possible, where the plants are to remain.

\section{ANNUAL VARIETIES}

The Shirley-Flowers exceedingly graceful and elegant; single; colors ranging from bluish white, delicate pink, rose and carmine, to bright sparkling crimson, occasionally blotcked and streaked with white. The best and most showy of all single poppies. Finest Mixed, pkt., $5 \mathrm{c}$.

California Poppy-See Eschscholtzia.

Cardinal-Very large, double flowers, beautifully fringed, of vivid scarlet color; height two feet.Pkt., $5 c$.

Double White Fringed-Tnis is the finest double white poppy. The plants are about two and onehalf feet high. The blooms are from three to four inches in diameter, perfectly double, finely fringed and of purest white. Pkt., $5 \mathrm{c}$.

\section{PERENNIAL POPPIES}

Iceland Poppy (Nudicaule)-The plants are of graceful, neat habit, with bright green, fern-like foliage from which issue slender stalks about 12-in. high, bearing their brilliant and fragrant flowers in endless profusion. Mixed colors. Pkt., 10c.

Oriental Poppy-Gorgeous, showy flowers, measuring 6.7 in. across, of dazzling, brilliant colors, mostly shades of red; are perfectly hardy, living through our winter with but little protection, and increase in size and beauty every year. Mixed colors. Pkt., 10c.

Portulaca (Rose Moss) - Hardy annual plants of easy culture. Will grow and bloom abundantly all summer in a dry, hot location, where most other plants would soon die. The flowers are of the richest colors and make a beautiful border. Single, mixed colors, pkt., 5c. Double, mixed colors, pkt., 10c.

Pyrethum-See Feverfew.

Ricinus-See Castor Beans.

Rhodanthe (Everlasting Flower)-One of the finest and most beautiful of the many rarieties of everlastings; for winter pouquets, the blossoms should be gathered before fully expanded, and if dried in the shade, will retain their brilliancy for years. Rose and white mixed. Pkt., 5c.

Salpiglossis (Velvet Flower)-Beautitful garden annuals about 18 inches high, bearing large Petunialike flowers of gorgeous colors, laced and veined. Large flowerIng, mixed colors. Pkt., $10 \mathrm{c}$.

Salvia (Flowering Sage) - Fine plants with spikes of scarlet and blue flowers; good for pot culture or out-of-door bloom in summer; fine in groups. Sow seed in house.

Splendens-Brilliant scarlet. Pkt., 5c.

Scabiosa (H. A). (Mourning Bride)-Perfectly double flowers, useful for cutting; gracefully borne upon long slender stems; range of color from white to rich pink, crimson to deep red, lilac and black mixed. Pkt., 5c.

Schizanthus-Hardy annuals, growing one and one-half to two feet high and covered with bright, showy, butterfly-like blossoms. Large flowering. Mixed. Pkt., 10c.

Silene-See Catchfly.

Snap Dragon-See Antirrhinum.

\section{Stocks (Gilliflower)}

The Stock is one of the most popular annuals, either for bedding or pot culture; in brilliancy and diversity of color, fragrance, profusion and duration of bloom it is unsurpassed.

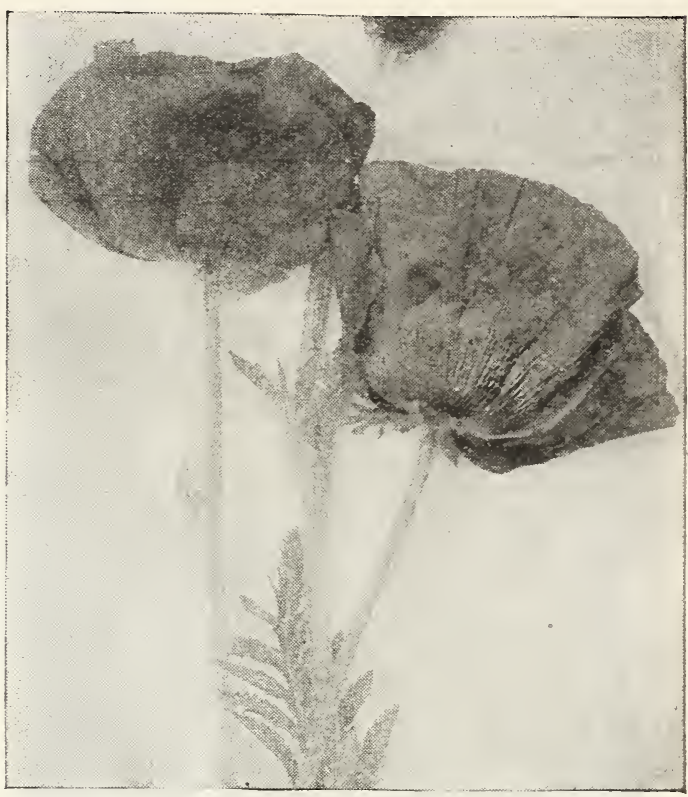

Shirley Poppy

Double German Ten Weeks-This favorite sum. mer variety comes into bloom early and is excellent for bedding out. Deliciously fragrant flowers and very desirable for cutting. Shades of white, red, purple, lavender and maroon. Mixed colors. Pkt., 5c.

\section{Sweet William}

A splendid old-fashioned plant, producing its large heads of beautifully colored, sweet-scented flowers in great abundance. It is hardy, easily grown and flowers the second year from seed.

Single Mixed-Magnificent sirain, flowers of large size, containing many attractive shades. Pkt., $5 \mathrm{c}$.

Double Mixed-Carefully saved from double flow. ers. Pkt., 5c.

Sunflower (Helianthus) - Hardy annuals. Valuable as a screen to hide unsightly places, and as a background for lawns. Hardy annual.

Double Chrysanthemum Flowered-A tall plant growing seven feet high and blooming profusely all summer. Flowers are double, large, round, golden, yellow and resemble chrysanthemums. Pkt., 5c.

Mammoth Russian-Very large. Usually grown for feed. The stalks are sometimes used tor fuel. Oz., 5c; 1/4 lb., 15c; Ib., 35c.

Thunbergia, or Black-Eyed Susan-A hardy annual climber, growing about four fcet long, and valuable for low fences or hanging baskets. Prefers a sunny situation. Blossoms are buff, orange or white, with dark centers. Mixed. Pkt.. 5c.

Trumpet Vine-See Bignonia.

Verbena-A half hardy trailing perennial of easy culture. It is well known as a bedding or border plant, and the improved large flowered and fragrant strains make it a handsome cut flower for low vases. Verbenas grown tlum veed are always thrifty and do not rust. Sow early in house, or out of doors in April

New Giant-Flowered Mixed-A new class of $\nabla$ er. benas which is of extraordinary beauty, and sur. passes all other varieties and strains in existence in size, perfection of form and richness of colors. The individual flowers are of great size. Large range of colors. Pkt., 10c.

Hybrida Mixed-All colors of the old sorts. Pkt., 5c.

Lemon Verbena-Pale green, delightfully scented foliage. Pkt., 10c. 


\section{Index to Catalogue}

\section{VEGETABLE SEEDS}

Page

Artichokes .........8

Asparagus $\ldots \ldots \ldots \ldots 8$

Beans . . . . . . . 9-10

Beets ............11

Beets, Stock .......11-12

Broccoli ...........12

Cabbage .........12-13

Cantaloupes .......2-4

Carrots ...........15

Cauliflower ........14

Celery ...........15

Corn, Sweet .......16

Corn, Pop ........16

Corn, Salad ........16

Cress ............18

Cucumbers ......6-17-18

Egg Plant ........18

Endive .......... 19

Gourds, Ornamental ....18

Herbs, Medicinal and Pot.19

Kale ...............19

Kohl Rabi .........19

Leek ...............19

Lettuce .........20

Melons, Musk .......21

Melons, Casaba .......22

Melons, Water .....5, 23

Mustard ..........24

Okra ............24

Onion Seeds ........25

Parsley ..........28

Parsnips .........28

Peas, Garden ......26-27

Peanuts ..............33

Pepper ............27

Pumpkins .........28

Radishes .........29-30

Rhubarb Seed .........30

Salsify ............. 31

Spinach .............

Squash $\ldots \ldots \ldots \ldots \ldots 31$

Tomatoes ............32

Turnips .......... 33
FLOWER SEEDS

Page

Aquilegia . . . . . . 39

Abronia ..............35

Abutilon ......................

Adlumia .............35

Accroclinium $\ldots \ldots \ldots \ldots 35$

Ageratum ..........35

Alyssum .............35

Amaranthus ........37

Ampelopsis .........37

Ammobium .........37

Antirrhinum .........37

Aquilegia $\ldots \ldots \ldots \ldots 37$

Armeria ...............

Asperula $\ldots \ldots \ldots \ldots 37$

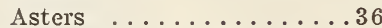

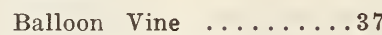

Balsam .............37

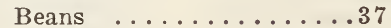

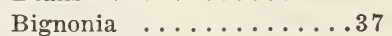

Brachycome ..........37

Browallia ............37

Cacalia .......................

Calendula ..........37

Calliopsis ...........37

Campanula ...........38

Canary Bird Vine.......38

Candytuft ...........38

Carnation ............38

Castor Beans ........38

Celosia .............38

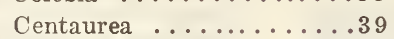

Chrysanthemum .......38

Clematis ...........38

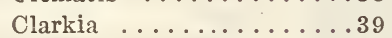

Cobaea ............39

Coleus .............39

Cosmos ............39

Cypress Vine .......... 39

Daisies ...........40

Datura ............40

Delphinium .......40

Dianthus ...........40

Eschscholtzia ........40

Flower Seeds .......34-48

Forget-me-not $\ldots \ldots \ldots \ldots 40$

Foxglove .........40

Four $0^{\prime}$ Clock ........40

Gaillardia ...........40

Globe Amaranth ......40

Godetia ...........41

Golden $\operatorname{Rod} . \ldots \ldots \ldots .41$

Gypsophila $\ldots \ldots \ldots \ldots \ldots$....
Page

Heliotrope .........41

Helianthus .........41

Hyacinth Bean ......41

Helichryism ........41

Hibiscus . . .......41

Hollyhock .........41

Humulus .........41

Job's Tears .........41

Kochia .........41

Lantana ...........41

Larkspur . . . . . . . . 44

Lavender ...........42

Linum . . . . . . . . 42

Lobelia . . . . . . . . . 42

Marigold .........42

Mignonette .........44

Mimulus ..........42

Moon Flower ........42

Morning Glory .......44

Musk Plant ........42

Myosotis ........43

Nasturtium .........43

Nicotiana ..........44

Nigeolia . . . . . . . 43

Enothera ............43

Pansy .............44

Passion Flower .......43

Petunia .........43.44

Pinks ............44

Phlox ..........44

Poppy ...........45

Portulaca ..........45

Pyretherum ........45

Rhodanthe ........45

Ricinus ...........45

Salpiglossis . . . . . 45

Salvia ...........45

Scabiosa ..........45

Scarlet Rurner ..........37

Schizanthus ............45

Shasta Daisy ........28

Silene ..........38.45

Stocks .............45

Sweet Peas ......46-47

Sweet William .......45

Sunflower ..........45

Thumbergia ........45

Veitchii ...........35

Verbena ............45

Wallflower .........46

Wistaria $\ldots \ldots \ldots \ldots 46$

Wild Cucumber .........46

Xeranthemum (.......46

Zinnia $\ldots \ldots \ldots \ldots \ldots 46$ 


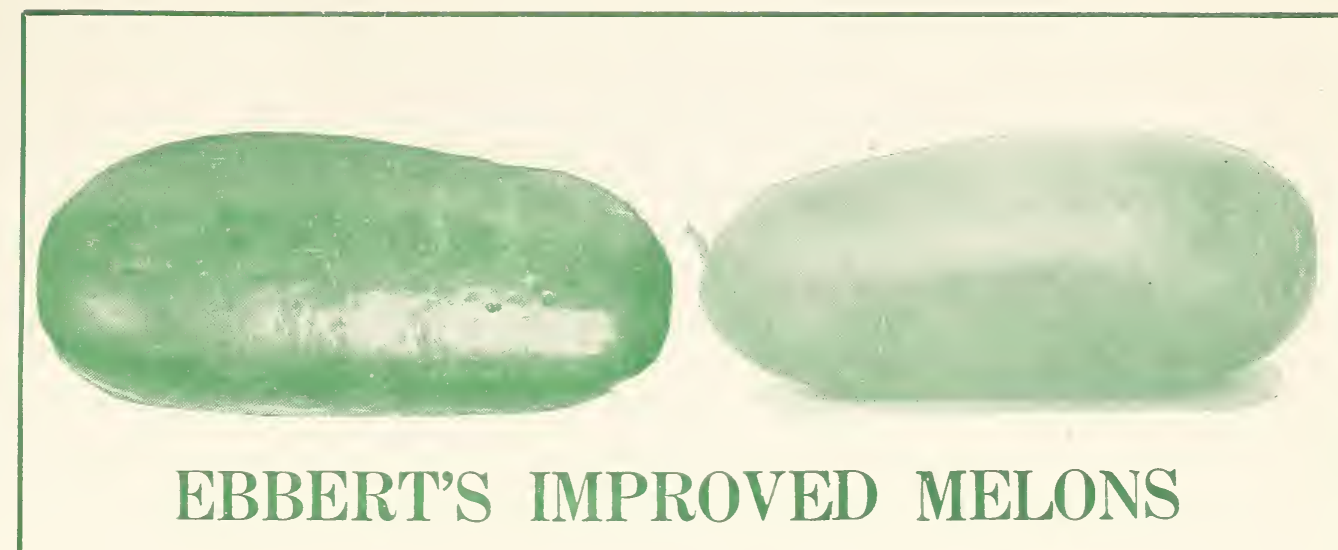

THE “SWEETEST OF ALL" WATERMELONS

EBBERT SEED CO.'S IMPROVED KLECKLEY SWEETS

THIS splendid variety is the finest flavored melon introduced in recent years. As a melon for the home garden and local market it is unexcelled. As originally inus.. duced, the rind was too thin and tender to admit shipping, but by careful selection this defect has been largely overcome, and at the present time is the favorite ship. ping melon with our Colorado growers, and rapidly growing in favor in other sections of the country.

In this new strain, now offered, there is developed a melon with a shell hard enough to carry to market, having been carefully selected for a series of years for this result. The rind is not thick, but the skin is so hard and tough that it resists the jolts and jars of travel to a remarkable degree.

The melon is large, averaging about 25 pounds in weight, oblong in form, with very dark green skin, flesh deep scarlet red, with solid heart, stringless, with few seeds set near the rind. The flavor is unexcelled. Don't fail to plant this splendid melon for home use or nearby markets.

Place your order early. Pkt., 5c; 0z., 10c; 1/4 Ib., 30c; Ib., \$1.00; 5 to $10 \mathrm{lbs}$, $90 \mathrm{c}$ per lb.; $10 \mathrm{lbs}$. or more, $85 \mathrm{c}$ per $\mathrm{lb}$.

IRISH GREY. A comparatively new variety that is becoming very popular as a shipping sort. Fruits long oval in shape and of light yellowish-grey color. The rind is exceptionslly hard and firm. The flesh is bright red, sweet, firm but free from any hard centers or stringiness. A very desirable variety for those who prefer a long, light colored shipping melon. Pkt., 10c: 0z., 15c: 2 oz., 25c; 1/4 Ib., 40c: lb., \$1.25.

\section{VINE SEEDS, WATERMELONS CUCUMBERS, CANTALOUPES}

\section{EBBERT SEED CO. ROCKY FORD, C O L O R A D O}




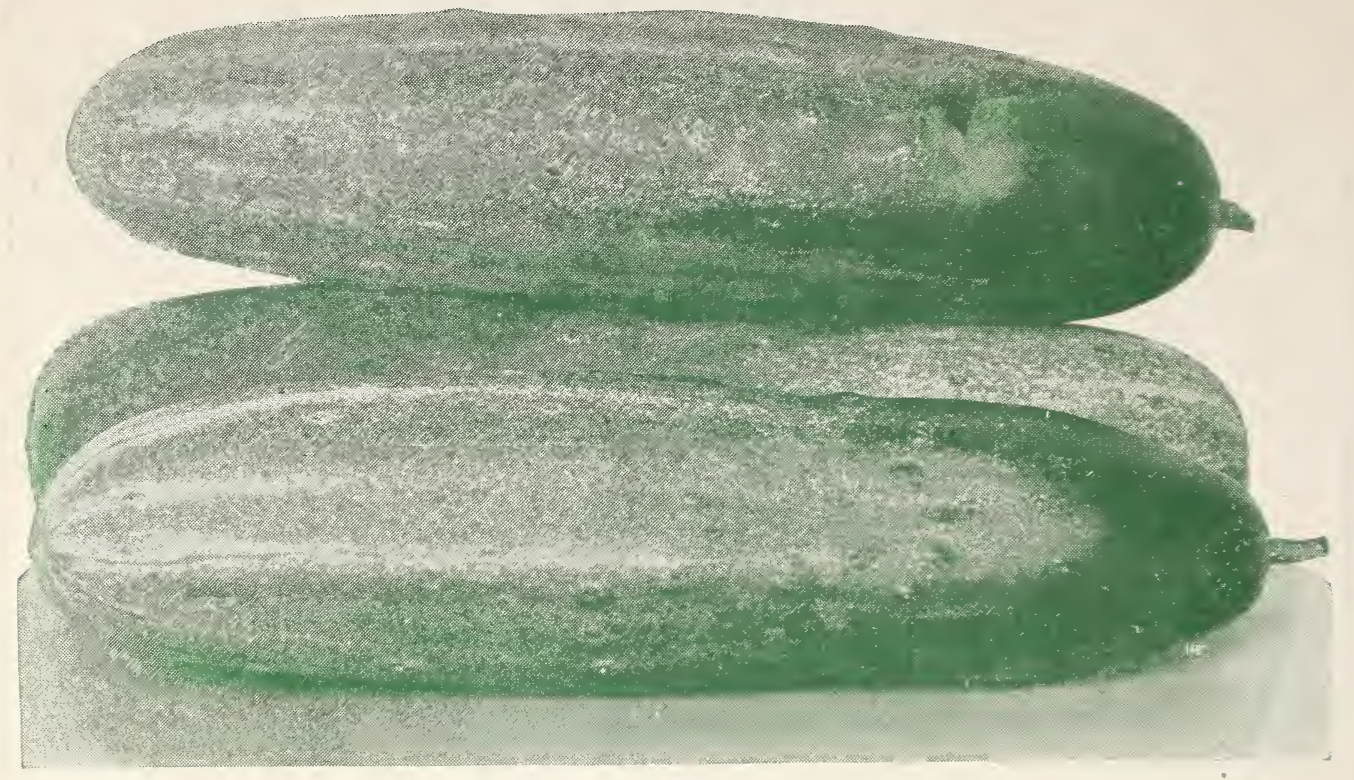

\section{CUCUMBERS}

\section{EBBERT'S EARLIEST OF ALL}

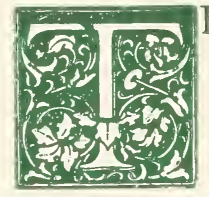

HE earliest of the slicing varieties. Fruit is straight, smooth and firm; excels all other varieties for pickling or slicing; vines vigorous and most productive, yielding more fruit per acre than any other variety grown for market; fruit good, even size, and dark green color. All our customers that planted our seed last year are increasing their orders for next season's planting, discarding the older varieties and using Ebbert's Earliest of All as the best on the market. We recommend this Cucumber above all others for Early Market use. Pkt., 5c; oz., 15c; 1/4 lb., 35c; lb., $\$ 1.25$.

\section{The Ebbert Seed Co. ROCKY FORD, COLORADO}

SPECIALISTS IN VINE SEEDS, CUCUMBERS, CANTALOUPES AND WATERMELONS 